\title{
Resumos de Dissertações de Mestrado e Teses de Doutorado apresentadas na Faculdade de Medicina de Ribeirão Preto - USP de julho a setembro de 2011
}

\section{Biologia Celular e Molecular}

\section{CORRELAÇÃO ENTRE MASTÓCITOS E A ANGIOGÊNESE DURANTE A PROGRESSÃO TUMORAL}

Devandir Antonio de Souza Júnior

Orientadora: Profa. Dra. Maria Célia Jamur

Tese de Doutorado apresentada em 23/08/2011

As células tumorais estão envoltas por um infiltrado de células inflamatórias, como linfócitos, neutrófilos, macrófagos e mastócitos. Diversas evidências indicam que os mastócitos estão associados a vários tipos de tumores. O papel dos mastócitos está diretamente relacionado ao seu conteúdo de grânulos. No entanto, sua função na angiogênese e na progressão do tumor permanece obscura. Este estudo tem como objetivo tentar compreender o papel dos mastócitos nesses processos. Os tumores foram quimicamente induzidos em camundongos BALB/c e a progressão tumoral foi dividida em três fases (I, II e III). Na fase I observamos um grande número de mastócitos, que aumenta na fase II e permanece inalterado na fase III. A expressão de proteases específicas de mastócitos (mouse mast cell protease) mMCP4, mMCP-5, mMCP-6, mMCP-7, e carboxipeptidase A foram analisadas nas três fases. Nossos resultados mostram que, com exceção de mMCP-4, a expressão da quimase mMCP-5, das triptases (mMCP-6 e 7) e da carboxipeptidase A aumentam durante a progressão do tumor, enquanto o número de mastócitos permaneceu constante da fase II para III. A atividade de quimase e triptase aumentam em todas as fases, mesmo quando o número de mastócitos se mantém constante entre as fases II e III. O número de novos vasos sanguíneos aumenta significativamente na fase I, enquanto que nas fases II e III ocorre, principalmente, um aumento no calibre destes vasos. Ainda, mMCP-6 e 7 são capazes de induzir a angiogênese in vitro. Assim, as alterações observadas na expressão das proteases de mastócitos, mesmo quando não ocorre aumento no número de mastócitos, sugerem que os mastócitos associados ao tumor estão em processo de maturação e que este processo se correlaciona com a angiogênese durante a progressão tumoral. O presente estudo sugere que os mastócitos estão envolvidos na indução da angiogênese em fases a iniciais do desenvolvimento do tumor e podem atuar na modulação dos vasos sanguíneos em fases mais tardias da progressão tumoral.

\section{IDENTIFICAÇÃO in silico E CARACTERIZAÇÃO DE POTENCIAIS SÍTIOS REGULATÓRIOS EM REGIÕES NÃO-TRADUZIDAS NOS GENOMAS DE Leishmania spp}

\author{
Elton José Rosas de Vasconcelos \\ Orientador: Prof. Dr. Luiz Ricardo Orsini Tosi \\ Tese de Doutorado apresentada em 23/08/2011
}

Os protozoários Leishmania spp. são organismos unicelulares, pertencentes à ordem Kinetoplastida e à família Trypanosomatidae. São os agentes causadores das leishmanioses. Os avanços recentes da pesquisa genômica sustentam a necessidade urgente de explorar a vasta informação contida no material genético desses parasitas. Após a obtenção dos genomas completos de diferentes espécies de Leishmania, as análises in silico se tornam cruciais para a melhor compreensão da biologia destes patógenos. Os tripanossomatídeos têm seus genes codificadores de proteínas agrupados em longas unidades policistrônicas compostas por genes não-relacionados funcionalmente e o controle da expressão gênica acontece, principalmente, por mecanismos pós-transcricionais. O alto grau de sintenia entre as espécies de Leishmania é acompanhado por sequências codificadoras (CDS) altamente conservadas e sequências intercodificadoras divergentes. Tendo como meta a identificação de elementos cis envolvidos no controle da expressão gênica, presentes nas regiões não- 
traduzidas (5' e 3'-UTRs) dos mRNAs, conduzimos uma investigação in silico, em larga escala, voltada à busca por sequências conservadas nas regiões intercodificadoras (CICS) dos genomas de Leishmania Leishmania major, Leishmania Leishmania infantum e Leishmania Viannia braziliensis. Uma combinação de ferramentas computacionais foi utilizada na construção de um pipeline que envolve diversas etapas desde a geração e formatação de arquivos de entrada (Shell/ Unix e scripts PERL), passando pela busca por similaridade de sequências (BLAST) e clusterização de CICS redundantes (SSAKE), até a automação do algoritmo para a predição das UTRs dos mRNAs (PRED-A-TERM) e enriquecimento gênico por meio de suporte estatístico (Teste Exato de Fisher, R scripts) à atribuição de termos do gene ontology (GO) para os genes que possuem CICS em comum na suas UTRs. Após a etapa de clusterização, foi gerado um grande conjunto de 16226 CICS “clusterizadas" e, dentre elas, encontramos diversos elementos já descritos na literatura (SIDERs, DIREs, repeats e ncRNAs). Eliminando as sequências correspondentes aos elementos já conhecidos, e atribuindo uma estratégia para resgatar os três principais núcleos de conservação, mais representados em cada CICS, ficamos com 9225 novas sequências intercodificadoras conservadas que chamamos de LeishCICS e, junto com os genes que as albergam em suas UTRs preditas, formaram uma base de dados denominada LeishCICS-clusters. As análises de enriquecimento gênico pela classificação de funções moleculares e processos biológicos GO e a consistência do padrão de variação dos níveis dos transcritos de L. (L.) infantum pertencentes a determinados LeishCICS-clusters, permitiu-nos especular que as LeishCICS possam estar envolvidas na co-regulação pós-transcricional de genes que as compartilham em suas UTRs. Ensaios de alteração da mobilidade em gel de eletroforese (EMSA) revelaram três LeishCICS como potenciais sítios de ligação de proteínas. Nossa abordagem computacional é capaz de identificar possíveis elementos regulatórios e representa um método preditivo para identificar grupos de genes funcionalmente relacionados e/ou co-regulados (regulons) em Leishmania spp.

\title{
CARACTERIZAÇÃO DO GENE LmHUS1 E DE SUA PARTICIPAÇÃO NO FENÔMENO DE AMPLIFICAÇÃO GÊNICA EM Leishmania spp
}

\author{
Vinícius Santana Nunes \\ Orientador: Prof. Dr. Luiz Ricardo Orsini Tosi \\ Tese de Doutorado apresentada em 30/09/2011
}

O parasita protozoário Leishmania apresenta um genoma plástico e dinâmico onde a amplificação gênica e translocações cromossomais são fenômenos comuns. Tal plasticidade sugere a necessidade de mecanismos robustos de reparo do DNA e de manutenção do genoma. A célula eucariótica desenvolveu sistemas de controle checkpoint que reconhecem estruturas alteradas de DNA e bloqueiam a progressão do ciclo celular permitindo que o reparo do DNA aconteça. Nestas células, o complexo heterotrimérico formado pelas proteínas Hus1, Rad9, e Rad1 participa nas etapas iniciais de reconhecimento e sinalização do estresse replicativo.

Neste trabalho mostramos que a proteína Hus1 homóloga de Leishmania major é uma proteína nuclear que melhora a capacidade do parasito em lidar com o estresse replicativo. A análise de northern e PCR em tempo real mostraram que, após a transfecção do gene, a linhagem selecionada apresenta níveis aumentados dos transcritos LmHusl. A utilização de um anticorpo anti-LmHusl demonstrou o aumento nos níveis da proteína nestas células. Ainda, a superexpressão de LmHus 1 confere resistência às drogas genotóxicas hidroxiuréia (HU) e metil metanosulfonato (MMS), e a resistência à HU correlaciona-se com a redução de dano no DNA após a expressão da LmHus 1 . A ruptura de um dos alelos LmHus 1 diminui os níveis do seu produto, compromete o crescimento do parasito e proporciona discreta diminuição na resistência às drogas genotóxicas. Resultados preliminares associam a expressão da $L m H u s I$ ao fenômeno de amplificação gênica em $L$. major. Além disso, a possível quinase Chk1, efetora da sinalização iniciada em Hus1, foi clonada e transfectada no parasito, o anticorpo anti-Chk1 também foi produzido.

Finalmente, considerando que LmHus 1 funcione na detecção do dano e controle de defeitos na replicação de DNA, formulamos a hipótese de que o produto deste gene atue na forquilha de replicação e participe no fenômeno de rearranjo do DNA e na formação de amplicons neste parasito. 


\title{
Bioquímica
}

\section{CLONAGEM E EXPRESSÃO DE CELULASES E HEMICELULASES DE Aspergillus niveus EM Aspergillus nidulans A773}

\author{
André Ricardo de Lima Damásio \\ Orientadora: Prof. Dra. Maria de Lourdes Teixeira de Moraes Polizeli \\ Tese de Doutorado apresentada em 01/07/2011
}

A pesquisa básica e aplicada em celulases e hemicelulases microbianas, além de gerar conhecimento científico, apresenta um enorme potencial biotecnológico. Uma fonte muito importante destas enzimas são fungos filamentosos, principalmente do gênero Aspergillus. Iniciou-se este trabalho com o sequenciamento do DNA genômico de Aspergillus niveus, fonte consolidada para produção extracelular de amilases, pectinases e xilanases. Dentro de aproximadamente 28762 contigs $(98$ pb - 31 kb) identificou-se 180 enzimas relacionadas à degradação da parede celular de plantas. Após seleção de 11 genes de interesse, os mesmos foram amplificados e isolados a partir do DNA genômico de A. niveus através de reações de PCR e clonados no vetor pExPYR nos sítios NotI e XbaI permitindo a secreção dirigida por um promotor de glucoamilase (GAp). Após confirmar as clonagens dos genes alvo por sequenciamento, estes foram transformados em $A$. nidulans linhagem A773 objetivando-se a expressão heteróloga e secreção destas enzimas. Seis enzimas foram expressas em níveis satisfatórios, endo-xilanase, arabinofuranosidase, arabinanase, xiloglucanase, celobiohidrolase I e celobiohidrolase II. A secreção "limpa" das enzimas alvo em A. nidulans linhagem A773 permitiu rápidos processos de purificação, com no máximo dois passos (troca iônica e filtração em gel), sendo que algumas proteínas foram purificadas após um único passo (ultra-filtração). A ORF do gene de celobiohidrolase I (CBHI) de A. niveus apresentou 1559 bp, codificando 532 resíduos de aminoácidos com massa molecular calculada de $53,6 \mathrm{kDa}$ e ponto isoelétrico de 4,68. Os ótimos de $\mathrm{pH}$ e temperatura foram 5,0 e $60^{\circ} \mathrm{C}$. Quanto à estabilidade térmica, atividade hidrolítica de $\mathrm{CBHI}$ permaneceu $100 \%$ após 60 minutos a $40^{\circ} \mathrm{C}$ e $50^{\circ} \mathrm{C}$. $\mathrm{A} 60^{\circ} \mathrm{C} \mathrm{e} 70^{\circ} \mathrm{C}$ o tempo de meia-vida foi de aproximadamente 25 e $10 \mathrm{~min}$., respectivamente. A análise da sequência de CBHI utilizando-se o software SMART sugeriu a existência de um domínio de ligação à celulose (CBD) na região C-terminal. O gene para endo-xilanase apresentou 890 bp codificando uma proteína com 275 aminoácidos (XAN) e massa molecular calculada de 31,3 kDa. A sequência deduzida de aminoácidos foi altamente homóloga com xilanases da família GH11. Os ótimos de $\mathrm{pH}$ e temperatura foram 5,0 e $65^{\circ} \mathrm{C}$. A estabilidade térmica desta enzima recombinante foi extremamente melhorada por imobilização covalente em glioxil agarose com $91,4 \%$ de atividade residual após 180 minutos a $60^{\circ} \mathrm{C}$, por outro lado, XAN solúvel apresentou meia-vida de 9,9 minutos sob a mesma temperatura. Cromatografia de afinidade em Concanavalina A e Jacalina-agarose seguida por análises em SDS-PAGE revelaram a presença de $O$ - e $N$-glicanas em XAN. Arabinofuranosidase (ABFase) com massa molecular de 88,6 kDa foi classificada como uma enzima da família GH51, baseando-se em similaridade de sequências. Caracterização de ABFase purificada resultou em hidrólise sob uma limitada faixa de $\mathrm{pH}(4,0$ a 5,0$)$ e temperatura ótima a $70^{\circ} \mathrm{C}$. Análises por SDS-PAGE revelaram a presença de $19 \%$ de N-glicanas, após tratamento com PNGase F. Ensaios de pull-down permitiram observar a ausência de módulos de ligação a carboidratos (CBM), corroborando com os resultados sugeridos por bioinformática. Imobilizou-se ABFase por adsorção iônica em diferentes suportes: agarose ativada com polímeros de polietilenoimino ( $\mathrm{Mw} 25000 \mathrm{Da}$ ), agarose ativada com brometo de cianogênio (CNBr), DEAE-Sepharose e Sepharose Q. O derivado em Sepharose $Q$ permaneceu totalmente ativo a pH 5,0 após 360 minutos a $60^{\circ} \mathrm{C}$, por outro lado, ABFase solúvel foi totalmente inativada após 60 minutos. Arabinanase (Arab43) com massa molecular calculada de $34 \mathrm{kDa}$ foi classificada como uma hidrolase da família GH43. Esta enzima foi ativa em uma faixa de $\mathrm{pH}\left(\mathrm{pH} 4,0\right.$ a 7,0) e temperatura ótima a $70^{\circ} \mathrm{C}$. A imobilização de Arab43 foi realizada via ligação covalente multipontual em diferentes suportes: glioxil IDA (iminodiacético)-Ni+2, glioxil amino, glioxil agarose e agarose ativada com $\mathrm{CNBr}$. A inativação térmica destas preparações revelou que a estabilidade de Arab43 imobilizada em glioxil aumentou 1,6 e 4,0 vezes (baseado no tempo de meia-vida) comparando-se com glioxil amino e Arab43 solúvel a $70^{\circ} \mathrm{C}$, respectivamente. $\mathrm{O}$ tempo de meia-vida dos derivados glioxil a $60^{\circ} \mathrm{C}$ foi $>48 \mathrm{~h}(\mathrm{pH}$ 5), $9 \mathrm{~h}(\mathrm{pH} 7)$ e 88 minutos (pH 9). Arabinoxilanas (Abx) da parede celular de plantas possuem uma estrutura complexa que requer a ação sequencial e sinergística de diferentes enzimas para sua total hidrólise. Neste contexto, realizou-se a co-imobilização de XAN e ABFase em glioxil agarose obtendo-se um derivado multi-enzimático aumentando a eficiência de hidrólise de Abx. Além disso, objetivando a redução de custos para produção de coquetéis enzimáticos, realizou o co-cultivo de algumas cepas mutantes de A. nidulans linhagem A773 expressando as enzimas já descritas, resultando na co-produção de ABFase, XAN, Arab43 e também de uma xiloglucanase (XEG). 


\title{
MicroRNAS NA RETINA E NO MÚSCULO soleus DE RATOS DIABÉTICOS: POSSÍVEIS IMPLICAÇÕES EM RETINOPATIA E ATROFIA MUSCULAR
}

\author{
Thaís Amaral e Sousa \\ Orientador: Prof. Dr. : Fernando Luiz De Lucca \\ Tese de Doutorado apresentada em 10/08/2011
}

O diabetes mellitus (DM) é uma condição crônica que pode levar a retinopatia e atrofia muscular. Os mecanismos moleculares responsáveis por estas complicações do DM não foram ainda totalmente elucidados. Os estudos sobre a participação de microRNAs (miRNAs) nas complicações associadas ao diabetes são ainda escassos. Os miRNAs constituem uma classe natural de pequenos RNAs não-codificadores (21-25 nucleotídeos) que controlam a expressão gênica através da repressão da tradução ou degradação do RNAm alvo. O presente trabalho teve como principal objetivo avaliar a expressão de miRNAs na retina e no músculo soleus de animais diabéticos, bem como avaliar a função destes RNAs não codificadores e suas possíveis implicações para o desenvolvimento da retinopatia e da atrofia muscular. Este estudo foi desenvolvido com ratos tratados com estreptozotocina (STZ) e os principais resultados foram: 1. O miRNA let-7b apresentou expressão reduzida na retina de ratos diabéticos, enquanto a expressão do miR-146 não foi alterada nestes mesmos animais. A diminuição da expressão do let- $7 b$ na retina de ratos diabéticos poderia induzir a expressão da Akt1(protein kinase B), o que resultaria no aumento da expressão de VEGF (vascular endothelial growth factor) e consequentemente na neovascularização da retina, importante característica da retinopatia diabética; 2 . O let-7b encontra-se super-expresso no músculo soleus no $3^{\circ}$ dia após o tratamento com STZ, retornando posteriormente ao nível do controle; 3 . A Akt1 foi validada como alvo direto do let-7b; 4 . A regulação negativa da expressão da Akt1 pelo let-7b ocorre de maneira sequênciaespecífica e resulta da inibição da tradução e não pela degradação do RNAm; 5. A inibição da expressão da Akt1 pelo let$7 b$ leva ao aumento da atividade do fator de transcrição Foxo3a e, consequentemente ao aumento da transcrição da atrogina-1, favorecendo a proteólise pelo sistema ubiquitina-proteassoma e o desenvolvimento da atrofia muscular; 6. O miR-150 apresentou o mesmo perfil de expressão em soleus e os mesmos alvos preditos para o let-7b, sugerindo a cooperação entre estes miRNAs no desenvolvimento da atrofia muscular; 7. O miR-101b encontra-se super-expresso no $5^{\circ}$ dia após o tratamento com STZ e seus possíveis alvos são membros downstream da Akt na via de sinalização IGF1(insulinlike growth factor 1)/Akt, sugerindo que este miRNA também contribui para atrofia muscular; 8. O miR-207 apresentou redução da expressão no soleus de animais diabéticos e possui a atrogina-1 como alvo predito, sugerindo que a diminuição da expressão deste miRNA poderia aumentar a proteólise através da aumento da atrogina-1.

Em resumo, os nossos resultados sugerem que o let-7b estaria envolvido no desenvolvimento da retinopatia e da atrofia muscular em animais diabéticos através da regulação da expressão de Akt1 e, portanto, o let-7b pode ser considerado como um potencial alvo terapêutico.

\section{ISOLAMENTO, IDENTIFICAÇÃO E CARACTERIZAÇÃO DA ATIVIDADE ANTI-INFLAMATÓRIA DE HEV B 13, UMA PROTEÍNA DERIVADA DO LÁTEX DA SERINGUEIRA HEVEA BRASILIENSIS - MODELOS EXPERIMENTAIS DE COLITE E ARTRITE EM CAMUNDONGOS}

\author{
Larissa De Bortoli Teixeira \\ Orientador: Prof. Dr. Joaquim Coutinho Netto \\ Tese de Doutorado apresentada em 15/08/2011
}

As doenças inflamatórias intestinais, bem como a artrite reumatóide, fazem parte de um grupo de distúrbios crônicos marcado pela ativação excessiva e inapropriada do sistema imunológico, as doenças inflamatórias imunomediadas. A interleucina-10, citocina com amplas propriedades anti-inflamatórias que têm se mostrado candidata à manipulação nas referidas patologias, pôde ser induzida em culturas de células mononucleares do sangue periférico humano por uma fração cromatográfica do soro do látex da seringueira Hevea brasiliensis, então denominada FrHb 3. Outras duas etapas de purificação foram necessárias para que seu componente ativo pudesse ser isolado, caracterizado e identificado. Através de digestão tríptica e espectrometria de massas, os spots desta fração purificada (nomeada FrHb 3.3.1) foram identificados como a esterase alergênica Hev b 13, também conhecida como early nodule-specific protein homologue.

Esta glicoproteína mostrou-se capaz de induzir um aumento na liberação monocítica de IL-10, mesmo em concentra- 
ções tão baixas quanto $1 \mu \mathrm{g} / \mathrm{mL}$. Além disso, quando presente em concentrações mais elevadas, reduziu os níveis de TNF nos sobrenadantes de células mononucleares cultivadas em ambas, ausência e presença do mitógeno linfocitário fitohemaglutinina. De forma alguma, porém, causou alterações na proliferação celular.

Ao ser avaliada in vivo, no modelo experimental de colite induzida por ácido 2,4,6-trinitrobenzenossulfônico, FrHb 3.3.1 diminuiu a perda de peso, a ocorrência de diarréia e prolapso retal nos camundongos aos quais foi administrada por gavagem oral. A análise histológica de segmentos do cólon desses animais demonstrou alta similaridade aos do grupo controle, estando atrelada a uma redução na extensão e severidade das alterações provocadas pela patologia.

O desenvolvimento da artrite reumatóide no modelo antigênico do desafio intra-articular (com albumina bovina sérica metilada) pôde ser influenciado pelo tratamento via oral dos camundongos com a fração FrHb 3.3.1. A avaliação clínica, baseada na gradação da descoloração do tendão e do edema lateral, colocou o grupo tratado em um patamar semelhante ao do falso-imunizado, e estes animais diferiram bastante daqueles não-tratados. Os cortes histológicos das articulações fêmoro-tibiais desafiadas neste último grupo também apresentaram características peculiares, como a presença de infiltrado inflamatório, a hiperplasia sinovial e a perda de cartilagem.

Conclui-se assim, que a fração FrHb 3.3.1, purificada de FrHb 3, possui um potencial modulatório de respostas inflamatórias e que este, pode ser proveniente de sua interação com células do sistema imune e da consequente modificação no padrão de citocinas por elas gerado.

\title{
Clínica Cirúrgica
}

\section{DESENVOLVIMENTO DE UM APARATO PARA A COLETA DO CONDENSADO DO EXALADO PULMONAR VISANDO À ANÁLISE DO ÓXIDO NÍTRICO EM INDIVÍDUOS HÍGIDOS}

\author{
Daniella Alves Vento \\ Orientador: Prof. Dr. Alfredo José Rodrigues \\ Dissertação de Mestrado apresentada em 02/09/2011
}

O óxido nítrico (NO) tem papel relevante nas diversas funções fisiológicas do organismo e nos mais variados sistemas que o compõe. Sabe-se que esta molécula é um constituinte normal do ar exalado na respiração de humanos e de animais. Tem como funções modular respostas inflamatórias e imunes bem como atuar na regulação do tônus vascular da musculatura lisa das vias aéreas. Esta molécula vem sendo reconhecida como importante marcador de lesão pulmonar, o que despertou a intensa investigação do NO no ar exalado. Uma metodologia não invasiva, de baixo custo e de fácil aplicação está sendo extensivamente estudada para a captação do ar exalado através do seu resfriamento e condensação, denominada Condensado do Exalado Pulmonar (CEP). É grande o interesse no estudo de doenças pulmonares inflamatórias, no entanto, observa-se uma considerável carência de evidências acerca dos níveis de concentração de mediadores inflamatórios, como o NO em amostras de indivíduos hígidos utilizando o CEP. Diante disso, decidiu-se elaborar um protótipo de aparato para coleta do condensado e empregar esta técnica para determinar valores de concentração de NO em uma amostra de voluntários hígidos. A metodologia de coleta utilizada foi baseada nas recomendações da força tarefa da American Thoracic Society/European Respiratory Society (ATS/ERS) para procedimentos de coleta de condensado, com o intuito de evitar erros metodológicos, padronizar e trazer mais evidências para auxiliar a inserção do método na rotina clínica, além de disponibilizá-lo para novas pesquisas. Para isto foram selecionados 116 indivíduos adultos hígidos de ambos os sexos, com idade entre 20 e 70 anos. O protótipo de aparato utilizado na pesquisa foi de fabricação artesanal e desenvolvido na Divisão de Cirurgia Torácica e Cardiovascular da Faculdade de Medicina da Universidade de São Paulo- FMRP/USP, visto que os aparatos comerciais são todos importados, de custo elevado e que ainda não forneceram evidências suficientes de que algum destes seria o padrão ouro para a coleta. O aparato foi eficiente para coletar o CEP e o NO foi detectável em todas as amostras. A média de NO foi de $13 \pm 14,4 \mathrm{mM}$, e não houve correlação com o gênero $(p=0,847)$ e idade $(p=0,811)$. Não foi observado correlação entre o NO e o volume de CEP coletado ( $p=0,944)$. O volume de CEP coletado é dependente do volume exalado total $(\mathrm{p}<0,001)$. A partir destes resultados pode-se verificar que o aparato é viável e eficiente. Não foram encontradas correlações entre a concentração de NO no CEP, idade e o gênero. O presente estudo poderá contribuir com futuras pesquisas de caráter comparativo e fornecer mais uma opção de aparato para coleta do condensado do exalado pulmonar, provendo baixo custo, reprodutibilidade e reutilização do aparato. 


\title{
EXPRESSÃO DE GENES DA VIA WNT EM CRANIOFARINGIOMAS
}

\author{
Carlos Eduardo Barros Jucá \\ Orientador Prof. Dr. Hélio Rubens Machado \\ Tese de Doutorado apresentada em 20/09/2011
}

Introdução: A patogênese do craniofaringioma $(\mathrm{CF})$ é pouco compreendida. Poderia decorrer da transformação neoplásica de restos celulares escamosos embrionários do ducto craniofaríngeo ou resultar da metaplasia de células da adeno-hipófise. Mutações no gene CTNNB1 foram identificadas em CFs adamantinomatosos. Dados recentes indicam um envolvimento da desregulação da expressão de miRNAs na patogênese e evolução dos CFs adamantinomatosos, potencialmente modulando a via de sinalização Wnt.

Objetivo: Avaliar a expressão de genes da via canônica de sinalização Wnt em CFs, correlacionando com a presença de mutação do gene $C T N N B 1$ e coma ocorrência de progressão tumoral.

Material e métodos: A expressão de genes relacionados à via Wnt foi avaliada através de PCR em tempo real em 14 amostras de CF, obtidas durante cirurgia e 8 de tecido hipofisário normal, obtidas de necrópsias. Selecionamos genes ativadores da via (WNT4), inibidores da via (SFRP1 e DKK3), genes do complexo citoplasmático de degradação da via (AXIN1 e APC), o gene que codifica a b-catenina (CTNNB1), genes ativadores (TCF7) e inibidores (CDH1) transcricionais, além de genes alvo (MYC, WISP2 e TP53) da via Wnt. A análise da expressão gênica foi realizada pelo método $2^{-\mathrm{DDCT}}$ e a expressão relativa "fold-change" calculada. A expressão gênica diferencial foi também calculada entre amostras de CF com ou sem mutação no gene CTNNBI e com ou sem progressão tumoral. Adicionalmente, foi realizada reação de imunoistoquímica (IHQ) em 11 das 14 amostras tumorais para identificação de -catenina, de c-myc e de WISP2.

Resultados: A expressão de todos os genes, com exceção do APC, esteve aumentada nos CF em relação aos controles: WNT4 (8,5x; $\mathrm{p}=0,01)$, sFRP1 (253,8x; $\mathrm{p}=0,0006), D K K 3$ (8,9x; $\mathrm{p}=0,0006), A X I N 1$ (7,76x; $\mathrm{p}=0,0003), C T N N B 1$ (3,2x; $\mathrm{p}=0,003), \operatorname{TCF} 7(12,4 \mathrm{x} ; \mathrm{p}=0,003), C D H 1$ (8,7x; $\mathrm{p}=0,03), \operatorname{MYC}(10,9 \mathrm{x} ; \mathrm{p}=0,0006), \operatorname{WISP} 2(59,16 \mathrm{x} ; \mathrm{p}=0,02)$ e TP53 (14,6x; $\mathrm{p}=0,0002)$. Os genes $T C F 7(11,26 \mathrm{x} ; \mathrm{p}=0,009)$ e $T P 53(3,91 \mathrm{x} ; \mathrm{p}=0,02)$ estiveram hiperexpressos nos pacientes com mutação do gene CTNNB1 em relação aos sem mutação. Os genes WNT4, SFRP1, DKK3, AXIN1, CDH1 e TP53 estiveram hiperexpressos nos pacientes com doença progressiva em relação àqueles com doença controlada. Houve uma correlação positiva entre a expressão do gene CTNNB1 e a expressão dos outros genes da via Wnt estudados, à exceção de WISP2. A -catenina esteve positiva e em distribuição aberrante na IHQ em 8 de 11 amostras testadas. A positividade de no mínimo $2+$ para a -catenina correlacionou-se positivamente com a progressão tumoral $(\mathrm{p}=0,01)$. A IHQ para WISP2 resultou negativa em todos os casos.

Conclusão: Nossos dados demonstram ativação global da via Wnt em CF. A presença de mutação no gene CTNNB1 ativa a transcrição de genes responsivos a b-catenina. A ativação de $S F R P 1, D K K 3$, AXIN1 e $C D H 1$, inibidores da via Wnt, sugere mecanismo de retroalimentação negativo. Portanto, não apenas mutações, mas também expressão gênica desregulada parece envolvida na patogênese dos CF, bem como na progressão tumoral. A expressão do gene WISP2 parece não ter participação neste processo.

\section{ANÁLISE DA EXPRESSÃO DOS microRNAS: miR-21, miR-221, miR-222, miR-15, miR-16 E DO GENE MGMT EM LINHAGENS DE GLIOBLASTOMA SUBMETIDAS AOS TRATAMENTOS COM RADIAÇÃO IONIZANTE E TEMOZOLOMIDA}

\author{
Felipe Amstalden Trevisan \\ Orientador: Prof. Dr. Carlos Gilberto Carlotti Junior \\ Tese de Doutorado apresentada em 20/09/2011
}

Objetivos: O limitado conhecimento da biologia molecular dos gliomas malignos pode dificultar o desenvolvimento das modalidades terapêuticas. Neste cenário, um dos maiores avanços dos últimos anos foi a identificação dos microRNAs (miRNAs), reguladores da expressão gênica. Tais moléculas tem importante papel em processos biológicos envolvendo o câncer, incluindo o glioblastoma. Os objetivos deste estudo foram avaliar o efeito da radioterapia e da Temozolamida sobre a expressão de miRNAs anti-apoptóticos (miR-21, miR-221 e miR-222) e próapoptóticos (miR-15a e miR-16), como também do gene MGMT, em linhagens celulares de glioblastoma (U343, T98G e U251). 
Casuística e métodos: As 3 linhagens celulares foram tratadas com radiação ionizante, Temozolamida e radiação associada a Temozolamida. A verificação da expressão dos miRNAs, como também do gene $M G M T$, foi realizada após 24 , 48 e 120 da exposição aos tratamentos propostos. Para tal, foi utilizado o método de PCR em tempo real.

Resultados: Observou-se uma queda estatisticamente significativa da expressão do miR-15a entre 48 e 120 horas na linhagem T98G tratada com radiação, aumento da expressão do miR15a entre os tempos de 24 e 120 horas na linhagem U251 tratada com radiação e Temozolamida e aumento expressão do miR-16 entre os tempos de 24 e 120 horas na linhagem U251 tratada apenas com radiação e com a associação de radiação e Temozolamida. Ocorreram também alterações de expressão dos miRNAs em função do tipo de tratamento adotado, para diferentes tempos de análise. Quanto ao gene $M G M T$, entre outros achados, verificou-se diminuição de sua expressão entre 24 e 48 horas, em células U343 tratadas com Temozolamida.

Conclusões: A radiação ionizante e a Temozolamida modificaram a expressão de todos os miRNAs estudados, principalmente nas linhagens celulares T98G e U251. A expressão do gene $M G M T$ foi modificada pela ação da radioterapia e Temozolamida, nas 3 linhagens celulares estudadas.

\title{
PERFIL DE METILAÇÃO DO GENE MGMT EM GLIOBLASTOMAS E A SUA CORRELAÇÃO COM A EXPRESSÃO DOS microRNAS: miR-21, miR-221, miR-222 E COM O GENE MGMT
}

\author{
José Paulo Montemor \\ Orientador: Prof. Dr. Carlos Gilberto Carlotti Junior \\ Tese de Doutorado apresentada em 27/09/2011
}

O tratamento dos tumores cerebrais, especialmente dos gliomas, é ainda um desafio, pois apesar de todos os tratamentos disponíveis atualmente e do grande avanço tecnológico na área da neuro-oncologia, os resultados não são satisfatórios. Os agentes alquilantes são hoje os principais quimioterápicos utilizados no tratamento dos gliomas malignos, sendo o mais importante deles a temozolamida. De um modo geral, o tratamento com temozolamida leva ao aumento da sobrevida média nos pacientes com glioblastomas, porém, apesar deste comportamento, não são todos os pacientes que se beneficiam do uso desta droga. Em função destes resultados, o estudo do ciclo celular e a compreensão da expressão de genes reguladores tumorais, têm se tornado o alvo principal nas pesquisas para o desenvolvimento de novas drogas para o tratamento destes tumores. Existem evidências na literatura que mostram a relação da expressão de alguns genes com a resposta dos tumores ao tratamento quimioterápico. O mais estudado atualmente é a influência da expressão do gene $M G M T$, relacionado ao reparo do DNA, com a resposta clínica à temozolamida. Acredita-se que o estado de metilação do gene $M G M T$ influencie na sua expressão. Mais recentemente foram também descritos RNAs reguladores da expressão gênica, os microRNAs. A expressão dos microRNAs não é totalmente conhecida nos gliomas malignos, porém existem evidências de que são importantes no desenvolvimento destes tumores. Com o objetivo de buscar novas opções de tratamento, estudamos a expressão e o grau de metilação do gene O6 Methylguanina DNA Methyltransferase (MGMT) e dos microRNAs nos glioblastomas cerebrais e sua implicação no prognóstico dos pacientes portadores destes tumores, quando tratados com agentes alquilantes. Para o estudo foram utilizadas amostras tumorais de vinte e nove pacientes com diagnóstico de glioblastoma multiforme. Para a análise das amostras foram empregadas as técnicas de COBRA para definir o perfil de metilação e a metodologia de PCR em tempo real para a quantificação do gene $M G M T$ e dos microRNAs miR-21, miR-221 e miR-222. Concluímos que a expressão do gene $M G M T$, é significativamente menor nas amostras dos glioblastomas multiformes metilados quando comparados com tecidos cerebrais não tumorais e com grupo de glioblastomas não metilados. O microRNA-21 tem sua expressão significativamente aumentada nas amostras de glioblastomas com $M G M T$ metilado, quando comparado com tecidos cerebrais normais, o que não acontece quando a comparação é entre o grupo de glioblastomas não metilados e o grupo controle. No que se refere aos microRNAs 221 e 222, a expressão não foi diferente nas amostras de glioblastomas, tanto com MGMT metilados como nos não metilados, quando comparadas ao grupo controle de tecido cerebral não tumoral. 


\title{
Clínica Médica
}

\section{EFEITOS DE DIFERENTES VISCOSIDADES DO BOLO DEGLUTIDO NAS CONTRAÇÕES E TRÂNSITO ESOFÁGICOS}

\author{
Juciléia Dalmazo \\ Orientador: Prof. Dr. Roberto Oliveira Dantas \\ Tese de Doutorado apresentada em 17/08/2011
}

Introdução: A motilidade esofágica normal depende da integridade dos mecanismos neurais de controle, intrínsecos e extrínsecos, além da contratilidade adequada das musculaturas do órgão. A viscosidade do bolo deglutido pode influenciar a motilidade e o trânsito pelo esôfago.

Objetivo: Avaliar a função do esôfago, em voluntários saudáveis, após deglutição de bolos com diferentes viscosidades, avaliados pela manometria e impedanciometria, estudar o efeito da posição corporal nesta função e a percepção pelo sujeito do trânsito durante a deglutição.

Casuística: O estudo foi realizado em 26 pessoas assintomáticas, 13 homens e 13 mulheres com idades variando entre 18 a 60 anos, média de 36,6 anos.

Material e Método: Medidas do trânsito e da contração esofágica foram realizadas com exame de impedância combinada com a manometria. Deglutições de $5 \mathrm{~mL}$ foram feitas em duplicata nas posições sentada e deitada utilizando os seguintes bolos: gel (engrossante Nutílis) viscosidade $2297 \mathrm{cP}$; sistema coloidal (iogurte natural), viscosidade $1368 \mathrm{cP}$; suspensão (sulfato de Bário), viscosidade $933 \mathrm{cP}$; e solução eletrolítica (Gatorade®), viscosidade $43 \mathrm{cP}$. A avaliação da percepção foi realizada por um questionário após cada deglutição.

Resultados: As contrações apresentaram maior amplitude, maior duração e maior área da contração na região distal do EIE e na posição deitada quando comparada com a posição sentada. O trânsito foi mais longo na região distal do EIE e na posição deitada quando comparada com a posição sentada. Na posição sentada à propagação da contração peristáltica foi mais lenta para o Gatorade ${ }^{\circledR}$, e o trânsito pelo esôfago foi mais lento com o iogurte. Em parte proximal do esôfago a amplitude da contração foi maior para o Nutilis® e na parte distal foi maior para o bário.

Conclusão: A viscosidade dos bolos pode não ser a única característica que determina o trânsito e as contrações esofágicas. A posição corporal pode afetar a avaliação da motilidade esofágica. A percepção do trânsito pelo esôfago pode não estar associada com alterações da passagem do bolo e/ou das contrações esofágicas, portanto nos voluntários saudáveis o aumento da percepção da passagem do bolo pode ser devido à hipersensibilidade.

\section{ESTUDO COMPARATIVO DOS NÍVEIS DAS CITOCINAS INFLAMATÓRIAS ASSOCIADAS A MUCOSITE ORAL APÓS A UTILIZAÇÃO DO LASER DE BAIXA INTENSIDADE EM PACIENTES SUBMETIDOS AO TRANSPLANTE DE CÉLULAS-TRONCO HEMATOPOÉTICAS}

\author{
Vivian Youssef Khouri \\ Orientador: Prof. Dr. Júlio César Voltarelli \\ Tese de Doutorado apresentada em 17/08/2011
}

Cavidade bucal e é causada pela ação da quimioterapia e radioterapia utilizadas no tratamento oncológico. Acomete pacientes submetidos a altas doses de quimioterapia, radioterapia e também, pacientes submetidos ao transplante de células tronco hematopoéticas (TCTH) com regime de condicionamento mieloablativo. Várias terapêuticas foram testadas para prevenir e tratar a $\mathrm{MuO}$, sendo uma das mais recentes o laser de baixa intensidade que tem como efeitos analgesia, antiinflamatória e reparação tecidual. O objetivo desse trabalho foi avaliar a influência das citocinas inflamatórias na saliva e no plasma sanguíneo e de marcadores do estresse oxidativo, da saliva sobre a intensidade da $\mathrm{MuO}$, nos pacientes submetidos ao TCTH alogênico e tratado com laserterapia, na Unidade de Transplante de Medula Óssea do Hospital das Clínicas da Faculdade de Medicina de Ribeirão Preto da Universidade de São Paulo. Participaram do presente estudo pacientes que receberam a administração de regime de condicionamento mieloablativo para a realização do TCTH alogênico para doenças hematológicas e onco hematológicas. Os pacientes participantes apresentavam idade igual ou acima de 12 
anos, sendo 7 pacientes do sexo masculino e 7 do sexo feminino (média de idade foi de 30,07 anos). Foram selecionados 14 pacientes divididos em 2 grupos: grupo 1: submetido à laserterapia $(\mathrm{N}=8)$ e grupo 2 (luz placebo) $(\mathrm{N}=6)$. $\mathrm{O}$ grupo $\mathrm{I}$ foi irradiado com o laser de AlGaInP $(660 \mathrm{~nm})$, com potência de $15 \mathrm{~mW}$, na dose de 3,8 J/cm², tempo 10 segundos, desde o início do regime de condicionamento até o pega da medula. Foram utilizadas as escalas da World Health Organization (WHO) e a "Oral Mucositis Assesment Scale" (OMAS) que avaliam, respectivamente, os sinais e sintomas da MuO, de modo geral, e o tipo de eritema e a extensão das ulcerações na cavidade bucal. Foram coletados sangue e saliva, antes do regime de condicionamento e no nadir da neutropenia, para dosagens das citocinas TNF-a, IL-1b e IL-6, utilizando o teste ELISA. Utilizando técnicas espectrofotométricas, foram analisados alguns marcadores do estresse oxidativo, como a glutationa reduzida (GSH) e o malonaldeído (MDA), na saliva. Houve também a inclusão de um grupo controle (voluntários hígidos). Foi utilizado modelo de regressão linear com efeitos mistos, teste de Fisher e Wilcoxon, com nível de significancia p<0,05 para análise dos resultados. Os resultados clínicos mostraram diminuição da gravidade da MuO, no grupo 1 em relação ao grupo 2, de acordo com as escalas escolhidas. Usando a OMAS, a mucosite foi menor no grupo 1 p=0,01.Analisando os níveis das citocinas inflamatórias, no plasma sanguíneo e na saliva, observamos que o laser não reduziu os níveis dessas citocinas, no grupo 1. Houve aumento de produto do estresse oxidativo (MDA) em ambos os grupos, enquanto o produto antioxidante GSH reduziu-se significativamente apenas no grupo não submetido à laserterapia. Conclui-se que o laser de baixa intensidade foi eficaz, clinicamente, na diminuição da $\mathrm{MuO}$ e que seu mecanismo de ação parece não estar ligado à redução das citocinas inflamatórias, mas à preservação de substâncias antioxidantes.

\section{TRANSPLANTE DE CÉLULAS-TRONCO MESENQUIMAIS HEPÁTICAS PRODUTORAS DE FATOR IX HUMANO EM CAMUNDONGOS HEMOFÍLICOS B}

\section{Andrielle de Castilho Fernandes}

Orientador: Prof. Dr. Dimas Tadeu Covas

Tese de Doutorado apresentada em 26/08/2011

Hemofilia B é uma doença genética ligada ao cromossomo X e consiste na deficiência do fator IX (FIX) da coagulação sanguínea. O fígado é o principal local de síntese da proteína FIX e uma fonte aternativa para obtenção de célulastronco mesenquimais (CTMs). Postula-se que as CTMs são imunoprivilegiadas e podem se enxertar em receptores imunocompetentes após transplante alogênico, além de serem consideradas potenciais veículos de entrega de proteínas com efeito terapêutico. Portanto, nós testamos a hipótese de que o transplante alogênico de CTMs derivadas do fígado (fCTMs) e modificadas geneticamente para expressar a proteína recombinante FIX (rhFIX) pode corrigir o fenótipo da hemofilia B murina. Para isso, as fCTMs foram isoladas do fígado de camundongos FVB-GFP e co-transduzidas para expressar o rhFIX e a Luciferase como gene repórter. As fCTMs/rhFIX/Luc foram caracterizadas e infundidas intravenosamente, intraperitonealmente e intra-hepáticamente em camundongos hemofílicos B (B6.129P2-F9 ${ }^{\mathrm{tm} 1 \mathrm{Dws} / \mathrm{J}}$ ) submetidos à lesão hepática via tetracloreto de carbono $(0,265 \mathrm{~g} / \mathrm{Kg})$ e a correção do fenótipo da hemofilia foi avaliada. Além disso, as fCTMs/rhFIX/Luc foram infundidas intra-hepáticamente em camundongos FVB-GFP submetidos a mesma lesão hepática e a atividade biológica do rhFIX foi avaliada. Por fim, as fCTMs não modificadas ou fCTMs/rhFIX ou fCTMs/ rhFIX/Luc em matrigel foram implantadas subcutaneamente em dois grupos: modelo singênico (FVB-GFP) e alogênico (hemofílico B) para a análise de rejeição celular. Os resultados demonstraram que as fCTMs mantiveram a morfologia fibroblastóide, o perfil imunofenotípico similar as CTMs murinas e o cariótipo normal após as modificações gênicas in vitro. Além disso, as fCTMs não modificadas ou fCTMs/rhFIX ou fCTMs/rhFIX/Luc não apresentaram potencial tumorigênico in vivo. Quando cultivadas em meio definido, fCTMs não modificadas e as fCTMs/rhFIX/Luc foram capazes de se diferenciar em adipócitos e osteócitos. Após o tratamento com vitamina K, as fCTMs/rhFIX/Luc secretaram $210 \pm 10$ mUI/10\%/24h de rhFIX biologicamente ativo. O transplante alogênico mostrou o aprisionamento celular pulmonar imediatamente após a infusão intravenosa das células $\left(8,83 \times 10^{5} \pm 2,11 \times 10^{5} \mathrm{f} / \mathrm{s}\right)$ e no $4^{\circ}$ dia o deslocamento celular para a região abdominal $\left(1,27 \times 10^{5} \pm 2,33 \times 10^{4} \mathrm{f} / \mathrm{s}\right)$. No $15^{\circ}$ dia houve um aumento de $32,8 \%$ da bioluminescência $\left(1,34 \times 10^{5} \pm 7,54 \times 10^{4} \mathrm{f} / \mathrm{s}\right)$, indicando enxertia e proliferação celular. Entretanto, no $21^{\circ}$ e $30^{\circ}$ dia os níveis voltaram a cair $\left(3,10 \times 10^{4} \pm 2,52 \times 10^{4}\right.$ e $2,35 \times 10^{4}$ $\left.\pm 2,18 \times 10^{4} \mathrm{f} / \mathrm{s}\right)$. Quanto à atividade biológica no plasma dos camundongos transplantados observou-se níveis elevados do $\operatorname{rhFIX}(0,78 \pm 0,28 \mathrm{UI} / \mathrm{mL})$ no $3^{\circ}$ dia, uma queda $(0,35 \pm 0,11 \mathrm{UI} / \mathrm{mL})$ no $5^{\circ}$ dia e no $15^{\circ}$ dia esses níveis voltaram a subir $(0,4 \pm$ $0,12 \mathrm{UI} / \mathrm{mL})$, o que representa um aumento significativo em relação ao animal hemofílico B controle $(0,03 \pm 0,02 \mathrm{UI} / \mathrm{mL})$. Contudo, no $21^{\circ}$ dia os níveis voltaram a cair $(0,18 \pm 0,07 \mathrm{UI} / \mathrm{mL})$ e $30^{\circ}$ os níveis permaneceram baixos $(0,07 \pm 0,003 \mathrm{UI} / \mathrm{mL})$, 
mas 2,3 vezes superior ao animal hemofílico B controle. O transplante alogênico via infusão intraperitoneal demonstrou forte correlação positiva $(\mathrm{r}=0,97)$ entre a bioluminescência emitida e atividade biológica do rhFIX. No $2^{\circ}$ dia após o transplante as células mantiveram na região hepática $\left(8,88 \times 10^{6} \pm 3,75 \times 10^{6} \mathrm{f} / \mathrm{s}\right)$ e níveis consideráveis de rhFIX foram observados $(0,45 \pm 0,06 \mathrm{UI} / \mathrm{mL})$. No $4^{\circ}$ dia foi detectado um aumento significativo de $94,8 \%$ na bioluminescência $\left(1,7 \times 10^{7}\right.$ $\left.\pm 1,2 \times 10^{7} \mathrm{f} / \mathrm{s}\right)$ e $45,5 \%$ no nível do rhFIX $(0,65 \pm 0,17 \mathrm{UI} / \mathrm{mL})$, indicando proliferação celular. Até $\mathrm{o} 21^{\circ}$ dia foi observado uma queda sutil da bioluminescência $\left(5,28 \times 10^{3} \pm 2,05 \times 10^{3} \mathrm{f} / \mathrm{s}\right)$ e do $\operatorname{rhFIX}(0,05 \pm 0,01 \mathrm{UI} / \mathrm{mL})$, indicando morte celular. Mesmo com a perda celular, a atividade biológica do rhFIX nos animais transplantados foi de 1,6 vezes superior do que no camundongo controle. $\mathrm{O}$ transplante alogênico via infusão intra-hepática demonstrou forte correlação positiva $(\mathrm{r}=0,98)$ entre a bioluminescência emitida e atividade biológica do rhFIX. No $2^{\circ}$ dia após o transplante um pico bioluminescente $\left(1,13 \times 10^{7} \pm 4,61 \times 10^{6} \mathrm{f} / \mathrm{s}\right)$ e níveis consideráveis de rhFIX plasmático $(0,58 \pm 0,16 \mathrm{UI} / \mathrm{mL})$ foram observados. A partir do $4^{\circ}$ dia até $\mathrm{o} 21^{\circ}$ dia foi observado uma queda sequencial da bioluminescência $\left(4^{\circ}\right.$ dia: $7,79 \times 10^{6} \pm 3,46 \times 10^{6} \mathrm{f} / \mathrm{s} ; 21^{\circ}$ dia: $1,34 \times 10^{3} \pm$ $\left.4,52 \times 10^{2} \mathrm{f} / \mathrm{s}\right)$ e do rhFIX ( $4^{\circ}$ dia: $0,49 \pm 0,21 ; 21^{\circ}$ dia: $\left.0,04 \pm 0,02 \mathrm{UI} / \mathrm{mL}\right)$, indicando morte das células transplantadas. Finalmente, o transplante singênico via infutrasão intra-hepática demonstrou uma correlação positiva $(r=0,69)$ entre a bioluminescência emitida e atividade biológica do rhFIX. No $2^{\circ}$ dia após o transplante um pico bioluminescente $\left(2,15 \times 10^{7}\right.$ $\left.\pm 7,18 \times 10^{6} \mathrm{f} / \mathrm{s}\right)$ e níveis consideráveis de rhFIX plasmático $(2,4 \pm 0,75 \mathrm{UI} / \mathrm{mL})$ foram observados. A partir do $4^{\circ}$ dia até o $30^{\circ}$ dia foi observado uma queda sequencial da bioluminescência ( $4^{\circ}$ dia: $1,13 \times 10^{7} \pm 2,85 \times 10^{6} \mathrm{f} / \mathrm{s} ; 30^{\circ}$ dia: $7,69 \times 10^{5} \pm 6,06 \times 10^{5} \mathrm{f} /$ s) e do rhFIX ( $4^{\circ}$ dia: $1,78 \pm 0,78 ; 30^{\circ}$ dia: $\left.0,79 \pm 0,39 \mathrm{UI} / \mathrm{mL}\right)$, indicando morte de quase todas as células transplantadas. Com relação ao experimento de implante celular, observou-se após 15 dias uma queda de $44 \%$ da bioluminescência no modelo singênico, enquanto que no modelo alogênico o sinal não foi detectado. Quanto aos linfócitos T infiltrados detectou-se uma maior quantidade nos implantes alogênicos quando comparados ao singênico, e maior proporção de CD3/CD8 do que CD3/CD4. Logo, conclui-se que é possível isolar as CTMs do fígado murino, modificá-las geneticamente com vetores virais e detectar níveis significativos da proteína rhFIX in vitro e in vivo. Esses dados sugerem a correção temporária do fenótipo da hemofilia B murina, por meio do transplante alogênico de CTMs produtoras de rhFIX, e indica que as CTMs são importantes carreadores de proteínas recombinantes com potencial terapêutico. Adicionalmente, este trabalho aponta a relevância da histocompatibilidade para a aplicação terapêutica das CTMs.

\title{
ATIVIDADES CICATRIZANTE E ANTIMICROBIANA DO ÓLEO-RESINA DE COPAÍBA (Copaifera langsdorffii) EM ÚLCERAS CUTÂNEAS
}

\author{
Daniela dos Santos Masson \\ Orientador: Prof. Dr. Marco Andrey Cipriani Frade \\ Tese de Doutorado apresentada em 01/09/2011
}

O estudo avaliou o óleo-resina (OR) proveniente da Copaifera langsdorffii quanto: à citotoxicidade; ao potencial cicatrizante em modelos animais; aos efeitos no modelo ex vivo de cicatrização da pele humana; à atividade antimicrobiana in vitro e in vivo. A citotoxicidade do OR $(1,10,50,100,500 \mathrm{e} 1000 \mu \mathrm{g} / \mathrm{mL})$ foi avaliada em culturas de fibroblastos 3T3 pela determinação da viabilidade e proliferação celular. A atividade cicatrizante foi avaliada em úlceras cutâneas em orelha de coelho, com aplicações tópicas diárias, por 21 dias, do OR in natura e em creme (10 e 25\%) e controles [creme base (Cr) e solução fisiológica]; no dorso de ratos, o tratamento consistiu de creme a 10\% e os mesmos controles, por 14 dias. As úlceras foram avaliadas por análise de imagem, índices de cicatrização e histologia nos dias 2, 7, 14 e 21. Parâmetros bioquímicos (hidroxiprolina e metaloproteinases) foram incluídos na investigação da cicatrização em ratos. No modelo ex vivo, os fragmentos de pele receberam diariamente: OR in natura, cremes a 10 e $25 \%$ e controles (Cr e meio de cultura (DMEM), por 21 dias, e foram avaliados nos dias $0,1,3,7,14$ e 21, por análises clínico-fotográfica e histológica. A atividade antimicrobiana in vitro foi avaliada pela determinação das concentrações inibitória e bactericida mínimas para bactérias Gram-positivas: S. aureus (ATCC 6538), S. pyogenes (ATCC 19615) e Enterococcus faecalis (ATCC 10541) e Gram-negativas: P. aeruginosa (ATCC 2327) e E. coli (ATCC 10538). A atividade antimicrobiana in vivo foi avaliada nas úlceras infectadas com S. aureus ou S. pyogenes em ratos, pela contagem bacteriana no exsudato e biópsias nos dias 2, 7 e 14 após úlceras e inoculação bacteriana além da atividade cicatrizante. O OR não apresentou toxicidade aos fibroblastos até $100 \mu \mathrm{g} /$ $\mathrm{mL}$, com viabilidade e proliferação de 90 a 100\%. Promoveu melhor cicatrização a 10\%, nos modelos orelha de coelho e dorso de ratos, enquanto, in natura ocasionou agressão tecidual. O modelo ex vivo manteve-se viável por 21 dias; a 10\% o OR inibiu a reepitelização das úlceras, diferente do controle (DMEM), evidenciando que sua atividade cicatrizante é dependen- 
te do processo inflamatório, ausente neste modelo. Apresentou atividade antimicrobiana in vitro (S. aureus, S. pyogenes e E. faecalis), a qual se manteve in vivo observada pelo estímulo cicatrizante do OR a $10 \%$ em creme nas úlceras infectadas com $S$. aureus ou $S$. pyogenes em ratos. Os resultados evidenciaram que o OR da C. langsdorffii não foi citotóxico, apresentou atividade antimicrobiana in vitro e in vivo, além de importante atividade cicatrizante dependente, essencialmente da fase inflamatória, demonstrada nos modelos animais e ausente no modelo ex vivo, contribuindo para o conhecimento quanto ao seu mecanismo de ação, eficácia e segurança para o uso clínico na cicatrização de úlceras cutâneas.

\title{
ANÁLISE DA GRANULARIDADE DA SÉRIE MIELÓIDE, POR CITOMETRIA DE FLUXO, NA SÍNDROME MIELODISPLÁSICA
}

\author{
Maria do Carmo Favarim Macedo \\ Orientador: Prof. Dr. Roberto Passeto Falcão \\ Dissertação de Mestrado apresentada em 05/09/2011
}

Síndrome mielodisplásica (SMD) é uma doença hematológica heterogênea, com variadas apresentações morfológica, citogenética e imunofenotípicas. Apesar de ser uma doença com critérios diagnósticos bem estabelecidos, pode ser difícil de caracterizá-la em situações em que se têm sinais de displasia mínimos e avaliação citogenética normal. Alterações morfológicas da linhagem mielóide são muito frequentes em pacientes com SMD e uma destas alterações é representada pela hipogranulação citoplasmática das formas mielóides, que pode ser identificada em sangue periférico e medula óssea. Tendo em vista que não há estudo do padrão de granularidade das células da linhagem mielóide por citometria de fluxo, o objetivo deste estudo foi avaliar a expressão de marcadores de superfície de grânulos em pacientes com SMD e um grupo controle. Para isso, foram recrutados 35 pacientes com diagnóstico estabelecido de SMD e 13 doadores de medula óssea. A expressão dos marcadores CD63, CD68, CD66b, CD88, fMLPR, CD18, CD35 e CD16 foi avaliada pelo método de Dot Plot e intensidade de fluorescência em medula óssea (MO) e sangue periférico (SP) nos dois grupos propostos. Os marcadores CD63 e CD18 apresentaram menores percentagens de expressão e intensidade de fluorescência no grupo de pacientes, tanto em MO quanto em SP. A intensidade de fluorescência do CD66b foi menor na MO do grupo de pacientes. No grupo de pacientes, os valores obtidos em SP e MO correlacionaram-se em todos os marcadores, com exceção do CD68 em intensidade de fluorescência e do CD35 em percentagem de expressão. Não foi encontrada diferença na intensidade de fluorescência e na percentagem de expressão dos marcadores entre os pacientes que apresentaram hipogranularidade na morfologia e nos que não apresentaram esta alteração. Conclui-se que as alterações imunofenotípicas podem ser identificadas mesmo que não haja alterações na morfologia e que a avaliação da expressão dos marcadores CD63 e CD18 pode ser auxiliar no diagnóstico de SMD.

\section{EFEITOS AGUDOS DO MAGNÉSIO NA CAPACIDADE DEEXERCíCIO DE PACIENTES COM DOENÇA PULMONAR OBSTRUTIVA CRÔNICA ESTÁVEL}

\author{
Angelica Floripedes do Amaral \\ Orientador: Prof. Dr. José Antonio Baddini Martinez \\ Tese de Doutorado apresentada em 08/09/2011
}

Existe interesse crescente no papel potencial do íon magnésio ( $\mathrm{Mg}$ ) sobre odesempenho do exercício. O Mg tem demonstrado efeitos farmacológicospotencialmente úteis em pacientes com DPOC e asma, tais como,broncodilatação, vasodilatação periférica e influência na contratilidademuscular. O presente estudo teve como objetivo avaliar os efeitos agudos daadministração endovenosa de Mg no desempenho de exercício de pacientescom DPOC estável. Vinte pacientes do sexo masculino com DPOC (66,2 \pm 8,3anos, VEF1: 49,3 \pm 19,8\%) receberam infusão de 2 g de sulfato de magnésioou solução salina em duas ocasiões distintas. A espirometria foi obtida antes e45 minutos após a infusão. Um teste cardiopulmonar (TCP) incrementallimitado por sintomas foi realizado em cicloergômetro, entre 90 e 120 minutosapós o término da infusão. A infusão de Mg esteve associada com reduçõessignificativas da capacidade residual funcional (-0,41 1) e volume residual $(-0,471)$, pressão arterial média $(-5,6 \mathrm{mmHg})$ e duplo produto cardíaco $(-734,8 \mathrm{mmHg}$.bpm) em repouso. O tratamento com $\mathrm{Mg}$ conduziu a aumentosignificativo da duração máxima do teste de exercício (53 seg), carga máximaatingida (8 w) e razão de trocas respiratórias $(0,06)$ no pico do exercício. Osresultados indicam que a administração IV aguda de Mg promove a redução dahiperinsuflação pulmonar estática e pequenas melhorias no desempenho deexercício em pacientes com DPOC estável. 


\title{
Farmacologia
}

\section{EFEITOS VASCULARES INDUZIDOS PELO PEPTÍDEO NATRIURÉTICO TIPO C (CNP) EM AORTA DE RATOS NORMOTENSOS E HIPERTENSOS RENAIS}

\author{
Laena Pernomian \\ Orientadora: Profa. Dra. Lusiane Maria Bendhack \\ Dissertação de Mestrado apresentada em 04/07/2011
}

O peptídeo natriurético tipo C (CNP) é descrito como agonista vasodilatador do músculo liso vascular de artérias e veias, podendo ser produzido e liberado do endotélio vascular frente a diversos estímulos. Este promove o relaxamento vascular através da interação com seu receptor associado à enzima guanilil ciclase particulada (GCp) de membrana, levando ao aumento dos níveis de GMPc ou pelo receptor NPR-C associado à inibição de enzima adenilil ciclase e ativação de enzima fosfolipase $\mathrm{C}$ e canais para $\mathrm{K}^{+}$, via proteína Gi. Esta vasodilatação é descrita envolver parcialmente a via NOGCs-GMPc, estando relacionada com a mobilização intracelular de cálcio. O modelo de hipertensão 2R-1C está associada ao consumo de NO, no ambiente celular, via reação com espécies reativas de oxigênio (EROs), especialmente ânion superóxido $\left(\mathrm{O}_{2}^{-}\right)$, caracterizando um prejuízo na vasodilatação dependente do endotélio. Desta forma, considerando as alterações descritas no modelo de hipertensão renovascular 2R-1C quanto ao estresse oxidativo e a importância do CNP como agonista vasodilatador, a hipótese do presente trabalho foi de que na aorta torácica isolada de ratos hipertensos $2 \mathrm{R}$ $1 \mathrm{C}$, o relaxamento vascular induzido pelo CNP estaria prejudicado devido o estresse oxidativo. Neste contexto, o objetivo do presente trabalho foi de elucidar os mecanismos celulares envolvidos nas respostas vasculares induzidas pelo CNP. Células endoteliais isoladas de aorta de ratos $2 \mathrm{R}-1 \mathrm{C}$ apresentaram menor $[\mathrm{NO}]_{c}$ comparadas as de $2 \mathrm{R}$, sugerindo disfunção endotelial. A exposição das células endoteliais à agente sequestrador de $\mathrm{O}_{2}^{-}$(Tiron) demonstrou a participação deste ânion em 2R-1C, mas não em 2R. CNP promoveu relaxamento de anéis de aorta de ratos $2 \mathrm{R} \mathrm{e} 2 \mathrm{R}-1 \mathrm{C}$, o qual foi mais pronunciado em preparações desprovidas de camada endotelial em 2R-1C. Hidroxicobalamina (sequestrador de $\mathrm{NO}^{0}$ ), mas não L-NAME (inibidor de NOS), causou redução da potência do CNP em 2R-1C. ODQ (inibidor de GCs) reduziu a potência em 2R E+, atenuando isoladamente o efeito máximo e o número de Hill em preparações E- de $2 \mathrm{R}-1 \mathrm{C}$ ao nível controle. Em presença do inibidor seletivo de GK (Rp-8-Br-PET-cGMPS) ocorreu atenuação da potência do CNP em todos os grupos experimentais, porém o efeito máximo do CNP somente foi reduzido daquelas preparações E-. A inibição da SERCA reduziu da potência do $\mathrm{CNP}$ em todos os grupos experimentais, porém o efeito máximo em $2 \mathrm{R}-1 \mathrm{C}$ foi reduzido ao nível controle. Sobre précontração induzida pela $\mathrm{EC}_{50}$ de solução de cloreto de potássio $(\mathrm{KCl})$ ocorreu atenuação de potência e efeito máximo do CNP em todos os grupos experimentais. Contudo, com a utilização de inibidores seletivos de canais para $\mathrm{K}^{+}$, apenas observou-se a participação de $\mathrm{BK}_{\mathrm{Ca}}$ e SK $\mathrm{Ca}_{\mathrm{Ca}}$ em 2R e 2R-1C e de KV em 2R-1C no relaxamento induzido pelo CNP. A inibição de NAD(P)H-oxidase (Apocinina) foi capaz de normalizar o efeito máximo em preparações E- de 2R-1C. A inibição de junções gap mioendoteliais (ácido 18-b-glicirretínico) promoveu redução da potência do CNP em 2R E+. Por fim, a inibição não-seletiva de COX (Indometacina) apenas reduziu a potência do CNP em preparações E+ de 2R. A partir da análise do conjunto de dados obtidos em estudos realizados em células endoteliais isoladas e funcionais pode-se concluir a participação do sistema de peptídeos natriuréticos sobre a modulação do tônus vascular em preparações isoladas de ratos $2 \mathrm{R}$ e 2R-1C. Assim, o relaxamento vascular induzido pelo CNP não se encontra prejudicado em aorta torácica isolada de 2R-1C. $\mathrm{O}$ endotélio vascular modula negativamente o relaxamento induzido pelo $\mathrm{CNP}$ em aorta de ratos $2 \mathrm{R}$ e $2 \mathrm{R}-1 \mathrm{C}$. Embora haja disfunção endotelial em 2R-1C, esta não é suficiente para alterar a mobilização de cálcio induzida pelo CNP. O relaxamento induzido pelo peptídeo envolve a participação de metabólitos de NOS e de espécie $\mathrm{NO}^{0}$, assim como as enzimas NAD(P)H oxidase, GCs, GK e SERCA parecem estar relacionadas com o efeito vasodilatador induzido pelo CNP mais pronunciado em 2R-1C. Assim também, a sinalização desencadeada pelo CNP leva à ativação de canais para $\mathrm{K}^{+}$em ambos os grupos, envolvendo a mediação através de junções gap mioendoteliais em 2R, mas não em 2R-1C.

\section{CONCENTRAÇÕES DE MMP-8, MMP-9, MPO, TIMP-1 E TIMP-2 NA SALIVA E CORRELAÇÕES COM PLASMA}

\section{César Arruda Meschiari}

Orientadora: Profa. Dra. Raquel Fernanda Gerlach

Dissertação de Mestrado apresentada em 06/07/2011

Metaloproteinases da matriz extracelular (MMPs) são uma família de endopeptidases zinco-dependentes conhecidas por degradar componentes do tecido conjuntivo em processos fisiológicos e patológicos. A regulação da atividade das MMPs pode ser feita pelos inibidores teciduais de metaloproteinases (TIMPs). 
A doença periodontal (DP) é a inflamação crônica em que atividade excessiva das MMPs e mieloperoxidase (MPO) são apontadas como responsáveis pela destruição dos tecidos suporte dos dentes.

Os componentes da saliva são derivados da vascularização local sendo possível encontrar neste fluido o reflexo de muitas moléculas presentes no plasma. Desta forma, os objetivos deste trabalho foram: 1) Comparar os níveis de MMPs, TIMPs e MPO na saliva total estimulada (STE) e plasma de pacientes com DP antes (DA) e após (DT) o tratamento periodontal não cirúrgico, e em voluntários saudáveis no início do estudo (CA) e após 3 meses (CT); 2) Avaliar se existe correlação entre os resultados.

Foram realizadas as dosagens de MMP-8, MMP-9, TIMP-1 e TIMP-2 pelo método de ELISA; a atividade gelatinolítica das formas da MMP-9 por zimografia; e a atividade da MPO por ensaio colorimétrico.

Houve uma menor atividade gelatinolítica, assim como menores concentrações de MMP-8 e TIMP-2 na STE de DT quando comparadas a DA $(\mathrm{p}<0,05)$. A atividade de MPO foi superior no grupo DA em relação a CA (p < 0,05). Foram encontradas correlações moderadas e estatisticamente significantes entre a MMP-9 quantificada por ELISA no plasma e todos os parâmetros resultantes da zimografia de STE, isto é, MMP-9 de massa molecular de 92 kDa $(r=0,37, p=0,002), 130$ $\mathrm{kDa}(\mathrm{r}=0,35, \mathrm{p}=0,003)$, a soma da sua atividade gelatinolítica $(130+92 \mathrm{kDa})(\mathrm{r}=0,43, \mathrm{p}=0,0002)$, gelatinase de $180 \mathrm{kDa}(\mathrm{r}$ $=0,35, \mathrm{p}=0,003)$, e soma da atividade gelatinolítica total $(180+130+92 \mathrm{kDa})(\mathrm{r}=0,37, \mathrm{p}=0,002)$. A MMP-8 plasmática apresentou correlação com a atividade gelatinolítica das bandas de $92 \mathrm{kDa}(\mathrm{r}=0,30 \mathrm{e} \mathrm{p}=0,01)$ e soma da atividade gelatinolítica $(130+92 \mathrm{kDa})(\mathrm{r}=0,24 \mathrm{e} \mathrm{p}=0,04)$ presentes na STE. Também foi possível observar uma correlação fraca entre a atividade gelatinolítica da MMP-9 de $92 \mathrm{kDa}$ do plasma e a atividade gelatinolítica da banda de $180 \mathrm{kDa}(\mathrm{r}=0,26 \mathrm{e} \mathrm{p}=$ 0,03), e uma correlação moderada entre o TIMP-2 do plasma e o TIMP-2 da STE ( $\mathrm{r}=0,32$ e p =0,04).

Os resultados mostram que a atividade gelatinolítica da STE pode estar refletindo as concentrações de marcadores inflamatórios sistêmicos tais como a MMP-8 e MMP-9, assim como a concentração de TIMP-2 na STE pode estar refletindo a concentração de TIMP-2 circulante.

A avaliação conjunta destes resultados sugere que existe uma atenuação de alguns dos marcadores inflamatórios analisados na STE e no plasma após o tratamento da DP, e que os níveis salivares e plasmáticos de alguns destes marcadores se correlacionam. Como a coleta de saliva é menos invasiva, mais estudos sobre a correlação destes marcadores nestes dois fluidos pode ser muito interessante.

\section{PARTICIPAÇÃO DA SEROTONINA NO EFEITO TIPO-ANTIDEPRESSIVO INDUZIDO PELA INIBIÇÃO DA NNOS NO HIPOCAMPO DE RATOS}

\section{Vinícius Antonio Hiroaki Sato}

Orientadora: Profa. Dra. Sâmia Regiane Lourenço Joca

Dissertação de Mestrado apresentada em 07/07/2011

Introdução: $\mathrm{O}$ óxido nítrico (NO) é considerado um importante neuromodulador que está envolvido com a neurobiologia da adaptação ao estresse e da depressão. A administração sistêmica ou intra-hipocampal de inibidores da NO sintase neuronial (nNOS) induz efeitos do tipo antidepressivo em modelos animais. Evidências recentes indicam que os efeitos sistêmicos dos inibidores da nNOS são dependentes dos níveis de serotonina no encéfalo. O sistema serotoninérgico do hipocampo dorsal, por ativação dos receptores serotoninérgicos do tipo $1 \mathrm{~A}\left(5 \mathrm{HT}_{1 \mathrm{~A}}\right)$, facilita a adaptação ao estresse e contribui para os efeitos comportamentais de drogas antidepressivas. Portanto, o objetivo do presente estudo foi testar a hipótese de que o efeito do tipo antidepressivo induzido pela administração hipocampal de inibidores da nNOS seria mediado pela facilitação da neurotransmissão serotoninérgica local e subsequente ativação de receptores $5 \mathrm{HT}_{1 \mathrm{~A}}$.

Métodos: Após cirurgia estereotáxica, ratos Wistar com cânulas-guia direcionadas ao hipocampo dorsal foram submetidos a sessão de pré-teste (15 minutos de nado) e receberam administrações locais das drogas: ${ }^{\text {ù }}$-propil-L-arginina (NPA, inibidor seletivo da nNOS: 0,00001 - $1 \mathrm{nmol} / 0,5 \mu \mathrm{L}$ ), fluoxetina (inibidor seletivo da recaptação de serotonina - ISRS; 1,3 e $10 \mathrm{nmol} / 0,5 \mu \mathrm{L}$ ), WAY100635 (antagonista seletivo para receptores $5 \mathrm{HT}_{1 \mathrm{~A}} ; 1,3$ e $10 \mathrm{nmol} / 0,5 \mu \mathrm{L}$ ) ou veículo (0,5 $\mu \mathrm{L}$ ). Vinte e quatro horas depois, o tempo de imobilidade foi registrado em uma sessão de 5 minutos de nado. Todos os protocolos foram aprovados por um comitê de ética local (Proc. $\left.\mathrm{N}^{\circ} 08.1 .1133 .53 .4\right)$.

Resultados: A administração intra hipocampal de NPA ou fluoxetina reduziu significativamente o tempo de imobilidade em animais submetidos ao teste do nado forçado, um efeito tipo antidepressivo. A administração de WAY100635 não induziu efeito por si, mas foi capaz de bloquear os efeitos induzidos por fluoxetina ou NPA.

Conclusões: A inibição da nNOS, pelo NPA, ou a inibição da recaptação de serotonina, pela fluoxetina, no DH induziu efeito do tipo antidepressivo de similar magnitude. O fato de que o pré-tratamento com WAY100635 foi capaz de bloquear os efeitos induzidos por NPA e fluoxetina sugere que ambos os efeitos são mediados por facilitação da neuro- 
transmissão serotoninérgica local e subsequente ativação de receptores $5 \mathrm{HT}_{1 \mathrm{~A}}$. Assim, esses resultados sugerem que níveis aumentados de NO no DH poderiam levar a um déficit na neurotransmissão serotoninérgica local e, portanto, predispor ao desenvolvimento das consequências comportamentais do estresse.

\title{
PAPEL DA SINALIZAÇÃO BDNF/TRKB DA SUBSTÂNCIA CINZENTA PERIAQUEDUTAL DORSAL (SCPD) NA MEDIAÇÃO DE COMPORTAMENTOS DEFENSIVOS ASSOCIADOS AO PÂNICO EM RATOS
}

\author{
Plínio Cabrera Casarotto \\ Orientador: Prof. Dr. Hélio Zangrossi Júnior. \\ Tese de Doutorado apresentada em 08/07/2011
}

A resposta de fuga gerada pela estimulação da substância cinzenta periaquedutal dorsal (SCPD) tem sido relacionada ao medo e, em termos psicopatológicos, ao transtorno de pânico (TP). A administração intra SCPD de drogas serotonérgicas ou GABAérgicas é capaz inibir esta resposta defensiva. Já drogas clinicamente eficazes no tratamento do TP, favorecem a neurotransmissão serotonérgica na SCPD.

Estas mesmas drogas estão entre as principais ferramentas na terapia de outros transtornos neuropsiquiátricos, como a depressão. A ação antidepressiva destes compostos tem sido associada a alterações nos níveis de fatores neurotróficos, como o BDNF (brain-derived neurotrophic factor). Por sua vez, esta neurotrofina tem sido implicada em diversas alterações neuroplásticas, como sobrevivência celular e fortalecimento de sinapses, em áreas como o hipocampo e córtex frontal. De interesse para o presente trabalho, a injeção de BDNF em áreas mesencefálicaas favorece a neurotransmissão serotonérgica na SCPD, entretanto ainda é desconhecido se este efeito contribui para a ação de drogas panicolíticas. O presente trabalho, portanto, verificou se os níveis de BDNF e de ativação de seu receptor (TRKB), na SCPD, foram alterados pelo tratamento repetido com drogas panicolíticas, bem como se esta neurotrofina é capaz de inibir respostas de fuga associadas ao pânico.

Para tal, iniciamos nossas análises avaliando o efeito do BDNF, injetado na SCPD, sobre o parâmetro de fuga avaliado no labirinto em T elevado (LTE) e estimulação elétrica da SCPD. Os resultados dos experimentos utilizando ratos Wistas com cânulas (LTE) ou quimitrodos (estimulação elétrica) cirurgicamente implantados na SCPD sugerem que o BDNF é capaz de inibir a resposta de fuga nos dois modelos. Ainda mais, este efeito é dependente da ativação de TRKB e envolve facilitação da neurotransmissão GABAérgica.

Na sequência, ratos Wistar receberam injeções de imipramina, desipramina, clomipramina e fluoxetina em regimes de curto (3 dias) e longo prazo (21 dias). Após o tratamento os níveis de BDNF e TRKB fosforilado (pTRKB) foram determinados na SCPD e hipocampo, utilizado como estrutura controle. Para fins comparativos, avaliamos o efeito do tratamento repetido com drogas com diferentes mecanismos de ação, como a buspirona, o clonazepam e diazepam sobre os níveis de BDNF nestas estruturas. Todos os antidepressivos foram capazes de aumentar os níveis de BDNF na SCPD e hipocampo após tratamento prolongado e nenhum efeito foi observado após o tratamento com as outras drogas. Entretanto os antidepressivos tricíclicos foram capazes de aumentar os níveis de BDNF na SCPD após tratamento de curto prazo. O tratamento de longo prazo com fluoxetina foi capaz de aumentar os níveis de pTRKB na SCPD. Por outro lado, o dois regimes de tratamento com imipramina apresentaram efeito sobre os níveis de pTRKB nesta estrutura. Porém, os níveis de pTRKB observados após 21 dias de tratamento com imipramina são maiores que após 3 dias.

Os resultados deste estudo indicam que o BDNF apresenta efeito tipo panicolítico mediado por GABA, enquanto a ativação da via BDNF/TRKB estár associada ao efeito de drogas antidepressivas.

\section{PARTICIPAÇÃO DO SISTEMA GLUTAMATÉRGICO DO CÓRTEX PRÉ-FRONTAL MEDIAL VENTRAL NA MODULAÇÃO DAS CONSEQUÊNCIAS COMPORTAMENTAIS DO ESTRESSE DE NADO FORÇADO}

\author{
Vitor Silva Pereira \\ Orientadora: Profa. Dra. Sâmia Regiane Lourenço Joca \\ Dissertação de Mestrado apresentada em 20/07/2011
}

Acredita-se que quantidades elevadas de glutamato estejam relacionadas à neurobiologia da depressão e trabalhos recentes indicam que a quantidade de glutamato cortical está aumentada em pacientes depressivos quando comparada a indivíduos sadios. Dentre as estruturas corticais, o córtex pré-frontal medial ventral (CPFMv), dividido em infralímbico (IL) 
e pré-límbico (PL), tem sido mais frequentemente implicado no desenvolvimento de transtornos mentais, como a depressão. Considerando evidências de que o IL e o PL podem agir de forma diferente quanto ao controle emocional em resposta ao estresse, o presente trabalho visou avaliar a hipótese de participação da neurotransmissão glutamatérgica do CPFMv, IL e PL, no desenvolvimento das respostas comportamentais ao estresse de nado forçado, um modelo preditivo de efeitos antidepressivos. Para tal, investigamos os efeitos induzidos pela administração no IL ou no PL, de LY 235959, um antagonista dos receptores glutamatérgicos do tipo NMDA, em três momentos diferentes, em animais submetidos ao teste do nado forçado.

A administração de LY 235959, no IL ou PL, produziu efeitos do tipo antidepressivo, sendo esse efeito sensível ao tempo de administração da droga em relação à exposição ao nado forçado. Sendo assim, foi observado efeito antidepressivo quando o bloqueio glutamatérgico no PL ocorreu imediatamente após o nado ou antes da re-exposição ao estresse; enquanto no IL, o tratamento promoveu efeito antidepressivo apenas quando administrado antes da re-exposição ao nado.

Portanto, os resultados sugerem que a neurotransmissão glutamatérgica mediada por receptores NMDA no CPFMv contribui para o desenvolvimento de consequências comportamentais do estresse, de modo que o bloqueio desses receptores facilitaria a adaptação ao estresse e induziria efeitos do tipo-antidepressivo. Os resultados sugerem, ainda, que o PL e o IL participam de maneira semelhante na modulação desses processos.

\title{
EFEITOS DA INIBIÇÃO FARMACOLÓGICA DO FATOR NUCLEAR KAPPAB SOBRE AS ALTERAÇÕES MORFO-FUNCIONAIS VASCULARES ASSOCIADAS À HIPERTENSÃO RENOVASCULAR
}

\author{
Stefany Bruno de Assis Cáu \\ Orientador: Prof. Dr. José Eduardo Tanus dos Santos \\ Tese de Doutorado apresentada em 27/07/2011
}

Há uma gama de evidências implicando as metaloproteinases de matriz extracelular (MMP) na disfunção e no remodelamento vascular associados à hipertensão. A expressão das MMPs pode ser regulada por meio da transcrição de seus respectivos genes, muitos dos quais possuem sequências consenso de reconhecimento para o fator transcricional kappaB (NF-kB). O ditiocarbamato de pirrolidina (PDTC) possui efeitos anti-hipertensivos associados ao seu efeito inibitório sobre a ativação do NF-kB. No entanto, os efeitos do tratamento como PDTC sobre o remodelamento vascular e a expressão de MMP-2 e MMP-9 induzidos pela hipertensão dois rins, um clipe (2R1C) ainda não é conhecido. Ratos sham operados ou hipertensos foram tratados com veículo ou PDTC (100 mg/Kg/dia) por gavagem durante oito semanas. A pressão arterial sistólica foi monitorada semanalmente por pletismgrafia de cauda. Anéis de aorta foram isolados para avaliar relaxamento dependente do endotélio. A análise morfométrica das aortas foi realizada em cortes corados com hematoxilina/eosina. A formação de espécies reativas de oxigênio (EROs) e a expressão da sintase induzida do óxido nítrico (iNOS) foram medidas em aortas. Os níveis e a atividade da MMP-2 e da MMP-9 foram determinados por zimografia em gel e in situ, respectivamente. O tratamento com PDTC atenuou o aumento da pressão arterial sistólica e reverteu a disfunção endotelial associadas à hipertensão 2R1C. Além disso, PDTC reverteu o remodelamento vascular aórtico e o aumento dos níveis de ERO e da expressão de iNOS na aorta do grupo de animais hipertensos tratados. Estes efeitos foram associados com a inibição da super-expressão de MMP-2 e MMP-9 vasculares e da atividade gelatinolítica. O tratamento com PDTC previne o aumento da expressão e atividade de MMPs e a disfunção e o remodelamento vascular induzidos pela hipertensão 2R1C. Nossos dados ainda sugerem que os efeitos do PDTC são mediados pela inibição da ativação do NF-kB.

\section{EFEITO DO CANABIDIOL SOBRE AS CONSEQUÊNCIAS COMPORTAMENTAIS E PLÁSTICAS PROMOVIDAS PELO ESTRESSE}

\author{
Alline Cristina de Campos \\ Orientador: Prof. Dr. Francisco Silveira Guimarães \\ Tese de Doutorado apresentada em 29/07/2011
}

Eventos estressantes podem levar a alterações cognitivas, emocionais e fisiológicas. Vários estudos sugerem que experiências estressantes contribuem para a precipitação de sintomas de transtornos de ansiedade. Estruturas límbicas como o córtex pré-frontal, amígdala, hipocampo e substância cinzenta periaquedutal parecem estar envolvidas no processamento de memórias aversivas e na expressão de comportamentos defensivos. Tanto a serotonina (via receptores 5HT1A) 
quanto os endocanabinóides parecem atenuar comportamentos defensivos, além de facilitar processos plásticos do SNC, tais como neurogênese e long term potentiation. O Canabidiol (CBD) é um constituinte não psicotomimético da Cannabis sativa, com propriedades ansiolíticas. Seus mecanismos, não são completamente elucidados, mas poderiam envolver a facilitação da neurotransmissão mediada por receptores 5HT1A ou CB1. Entretanto pouco se sabe sobre os efeitos deste fitocanabinóide sobre as consequências comportamentais e plásticas promovidas por exposições agudas ou crônicas a estressores. Neste sentido, o objetivo geral deste trabalho foi investigar os efeitos do CBD sobre as alterações comportamentais (aumento de comportamentos defensivos), morfológicas (alteração de processos proliferativos hipocampais) e moleculares (alteração de vias celulares e expressão de genes alvo) em encéfalos de roedores submetidos a modelos envolvendo exposição a eventos estressantes. Na primeira parte do trabalho, verificamos que a injeção repetida da CBD $(5 \mathrm{mg} / \mathrm{Kg}, 7$ dias), similarmente ao inibidor seletivo de recaptação de serotonina, paroxetina, foi capaz de atenuar os efeitos comportamentais de longo prazo, medidos no labirinto em cruz elevado (LCE), induzidos por uma única exposição ao predador (um modelo proposto de estresse pós-traumático). Esta resposta foi bloqueada pelo antagonista de receptores 5HT1A, WAY100635. Avaliamos também se a exposição ao gato e os tratamentos utilizados poderiam alterar a expressão do mensageiro RNA dos receptores CB1, 5HT1A e para a proteína sináptica Sinaptofisina no córtex frontal, formação hipocampal, complexo amidalóide e substância cinzenta periaquedutal (SCP) dorsal. Nossos resultados sugerem que a exposição ao predador parece modular de maneira complexa os genes 5HT1A no córtex e hipocampo e CB1 e sinaptofisina no complexo amidalóide e formação hipocampal. Nenhum dos tratamentos empregados foi capaz de reverter estas alterações. Não foram encontradas diferenças na expressão da neurotrofina BDNF nas estruturas analisadas. Em um segundo momento, nós também avaliamos a capacidade do CBD em aumentar processos proliferativos de células hipocampais in vitro e in vivo. Nossos resultados demonstraram que o CBD é capaz de aumentar a proliferação celular e a neurogênese via Erk1/Erk2 através da ativação dos receptores CB1 e CB2. Para estudar o envolvimento de processos proliferativos hipocampais sobre os efeitos comportamentais do CBD, utilizamos animais transgênicos GFAP-TK submetidos a um regime de estresse crônico. Observamos que nos animais estressados, o tratamento crônico com CBD (30mg/Kg) foi capaz de prevenir os efeitos comportamentais (aumento de comportamentos defensivos) e plásticos (processos proliferativos) induzidos pela exposição a estressores. Concluímos que o tratamento repetido com o CBD é capaz de atenuar comportamentos defensivos evocados pela exposição aguda ou crônica a estressores. E que estes efeitos parecem depender de mecanismos plásticos tais como o aumento da expressão de receptores 5HT1A e neurogênese hipocampal.

\title{
SISTEMA GLUTAMATÉRGICO E NITRÉRGICO DO HIPOCAMPO DORSAL DE RATOS E A MODULAÇÃO DA ATIVIDADE AUTONÔMICA DURANTE SITUAÇÕES DE ESTRESSE
}

\author{
Teophanes Barbosa Moraes Neto \\ Orientador: Prof. Dr. Fernando Morgan de Aguiar Corrêa \\ Dissertação de Mestrado apresentada em 23/08/2011
}

O hipocampo dorsal (HD) é uma estrutura do sistema límbico que está envolvida em processos emocionais, de memória e aprendizado. Alem disso, o HD também exerce influência sobre a atividade autonômica. Durante situações aversivas pode se observar tanto respostas autonômicas (aumento da pressão arterial, frequência cardíaca e queda da temperatura cutânea) quanto comportamentais. O HD está envolvido com diversas alterações associadas a reações defensivas e apresenta conexões com diversas estruturas que modulam essas respostas, fazendo parte de uma via responsável por modular as respostas durante situações aversivas. São observadas aumentos nas respostas autonômicas durante o estresse por restrição (ER). Durante a atividade do HD está aumentada. Além disso, é possível observar aumento dos níveis de glutamato no HD. A ativação de receptores glutamatérgicos do tipo NMDA no sistema nervoso central aumenta a síntese de óxido nítrico (NO) por ativação da isoforma neuronial da óxido nítrico sintase (nNOS). Além disso, esta interação, NMDA/NO, no HD parece ser importante nas reações defensivas. Portanto, no presente estudo nós observamos que a administração de glutamato no HD promove aumentos do sistema cardiovascular, similares a aqueles observados durante situações de estresse. Estas respostas cardiovasculares são associadas com um aumento da atividade simpática. Além disso, os efeitos do glutamato foram inibidos pela administração do AP7, um antagonista NMDA, do $\mathrm{N}^{\omega}$-Propyl-L-Arginine, um inibidor da nNOS ou do Carboxy-PTIO(S)-3-carboxy-4-hydroxyphenylglicine, um sequestrador de NO. Finalmente, a administração destas drogas foi capaz de reduzir as respostas autonômicas causadas pelo ER. Portanto, nossos achados mostram que o sistema glutamatérgico presente no HD esta envolvido com a modulação autonômica através de receptores do tipo NMDA e a ativação de nNOS. Além disso, esta via NMDA/NO está envolvida na modulação autonômica durante situações de estresse. 


\title{
EFEITOS CARDIOVASCULARES CAUSADOS PELA MICROINJEÇÃO DE ACETILCOLINA NAS SUBÁREAS DA SUBSTÂNCIA CINZENTA PERIAQUEDUTAL DE RATOS
}

\author{
Milena Deolindo Vieira \\ Orientador: Prof. Dr. Fernando Morgan de Aguiar Corrêa \\ Tese de Doutorado apresentada em 21/09/2011
}

A substância cinzenta periaquedutal (SCP) é uma importante região mesencefálica envolvida no controle cardiovascular. Dados na literatura relatam a ocorrência tanto de respostas pressoras quanto depressoras após estimulação química da SCP de ratos. Estudos de mapeamento das áreas da SCP indicaram que a SCP apresenta uma organização em colunas longitudinais, baseada na resposta cardiovascular à estimulação química (aminoácido excitatório) de áreas específicas. Desta forma, a SCP foi dividida funcionalmente em quatro colunas longitudinais, arranjadas ao longo do eixo rostro-caudal: a dorsomedial (SCPdm), dorsolateral (SCPdl), lateral (SCPl) e ventrolateral (SCPvl). O sistema colinérgico está envolvido no controle central da pressão arterial, além disso, presença de sinapses colinérgicas e receptores muscarínicos ao longo da SCP são descritas na literatura. No presente estudo nós relatamos os efeitos cardiovasculares à microinjeção de acetilcolina (Ach) nas diferentes subáreas da SCP bem como o receptor central envolvido na sua mediação. Diferentes doses de Ach nas subáreas da SCP causaram respostas hipotensoras e taquicárdicas de maneira dosedependente em ratos não anestesiados, apresentando uma DE50 de aproximadamente $45 \mathrm{nmol} / 50 \mathrm{~nL}$. Em paralelo nós observamos que a microinjeção de Ach nas subáreas da SCPl e SCPvl de ratos anestesiados causou resposta hipotensora sem alteração significativa da frequência cardíaca. Nenhuma alteração cardiovascular foi observada após a microinjeção de Ach na coluna SCPd (SCPdm e SCPdl) tanto em animais não anestesiados quanto em anestesiados. Estas respostas cardiovasculares desencadeadas após a microinjeção de Ach na SCPl e SCPvl foram bloqueadas de maneira dose-dependente pelo tratamento local com atropina (antagonista não seletivo de receptores muscarínicos), ou pelo pré-tratamento local com 4-DAMP. Contudo, as respostas à microinjeção de Ach não foram afetadas pela microinjeção local de pirenzepina (antagonista seletivo dos receptores M1/M3), sugerindo que tais respostas cardiovasculares após a microinjeção de Ach na SCP, são mediadas por receptores muscarínicos do subtipo M2, em ambas as colunas da SCP em animais não anestesiados, assim como, em animais anestesiados.

\section{Fisiologia}

\section{AVALIAÇÃO DA NEUROPLASTICIDADE EM MODELOS EXPERIMENTAIS DE EPILEPSIA DO LOBO TEMPORAL}

\author{
Victor Rodrigues Santos
}

Orientador: Prof. Dr. Norberto Garcia Cairasco

Dissertação de Mestrado apresentada em 22/08/2011

As epilepsias acometem entre 1-2\% da população mundial. De um modo geral, de todas as epilepsias quase um terço deste total de pacientes apresenta a síndrome epiléptica conhecida como Epilepsia de Lobo Temporal (ELT), a qual se instala geralmente após um insulto inicial ou em decorrência de outras patologias como, por exemplo, trauma ou tumor, e parece ser decorrente de anormalidades intrínsecas do lobo temporal tais como, amígdala, hipocampo e córtex piriforme. Depois de um período de latência variado, promove o surgimento de crises convulsivas. Dentre os pacientes que apresentam ELT, cerca de 20 a 30\% deles apresentam resistência ao tratamento farmacológico.

Para melhor estudar os processos plásticos envolvidos no processo de epileptogênese ocorridos após a instalação do insulto inicial que levam ao aparecimento de crises recorrentes espontâneas, ratos Wistar foram eletricamente estimulados na amígdala para indução de Status Epilepticus (SE). Foram feitas histoquímicas e immunohistoquímica para marcar neurônios ativados (c-Fos+), novos neurônios (Doublecortin - DCX+) e em degeneração (FluoroJade C - FJC+) após as crises.

Após a indução do SE observamos que quanto mais graves as crises, maior o número de áreas ativadas (c-Fos+) e maior número de neurônios em degeneração (FJC+). Além disso, não houve associação direta entre as áreas cerebrais ativadas e grau de neurodegeneração, nem associação entre gravidade do SE e intensidade de neurogênese (DCX).

A segunda fase deste projeto, executada na University of Cincinnati, refere-se ao estudo do impacto do SE, induzido por pilocarpina (PILO) sistêmica, sobre a neurogênese hipocampal. Utilizando a injeção de BrdU, para marcar o 
dia do nascimento de novos neurônios granulares, em camundongos Thyl-GFP foram submetidos ao SE por PILO. Foram analisadas a plasticidade dendrítica de neurônios granulares em fase de maturação (imaturas, 1 semana) e maduras ( 8 semanas). As células imaturas sofreram drásticas modificações na sua morfologia e na densidade dendrítica. Por outro lado, as células maturas não sofreram alterações morfológicas na árvore dendrítica, mas apresentaram uma intensa redução na densidade dos espinhos dendríticos, mostrando assim que as células imaturas estão mais suceptíveis ao impacto das crises epilépticas.

\title{
Genética
}

\section{POLIMORFISMOS NOS RECEPTORES DE ADENOSINA, SUAS ASSOCIAÇÕES COM CARACTERÍSTICAS FISIOPATOLÓGICAS E AVALIAÇÃO DE COMPONENTES NA BIOSSÍNTESE DA ADENOSINA EM PACIENTES COM DOENÇA FALCIFORME}

\author{
Carolina Dias Carlos
}

Orientador: Prof. Dr. Rodrigo Alexandre Panepucci

Dissertação de Mestrado apresentada em 01/07/2011

Na Anemia Falciforme em situações de baixa tensão de oxigênio, a hemoglobina mutante $\mathrm{S}(\mathrm{HbS})$ sofre polimerização promovendo a falcização das hemácias, que podem aderir ao endotélio vascular, causando a oclusão de vasos (VO) e isquemia tecidual (crises dolorosas) que caracterizam o quadro clínico da doença. Além disso, os pacientes falciformes apresentam outras manifestações clínicas como o priapismo, alterações ósseas, certas complicações pulmonares entre outros. Além das células eritróides, células endoteliais, leucócitos e plaquetas também desempenham um papel fundamental na fisiopatologia da anemia falciforme. A hidroxiuréia (HU), na anemia falciforme, aumenta a produção de hemoglobina fetal $(\mathrm{HbF})$ em células eritróides, reduzindo a polimerização da $\mathrm{HbS}$, diminuindo os sintomas clínicos dos pacientes. O aumento da $\mathrm{HbF}$, no entanto, não implica necessariamente na melhora clínica, indicando desta forma a potencial ação da HU sobre outros processos. Estudos recentes vêm relacionando priapismo e asma com elevados níveis de adenosina. Devido a esta importância da adenosina relacionada a patologias comuns a AF, tivemos como objetivo identificar polimorfismos em genes de receptores de adenosina e na adenosina deaminase e verificar a possível associação entre as manifestações clínicas, além de investigar o papel da HU na modulação de marcadores envolvido na síntese e degradação da adenosina. Foram analisados diversos sítios polimórficos nos genes que codificam ADORA1, ADORA 2b, ADORA 3 e ADA, seguindo com a genotipagem em pacientes com AF, comparando afetados e não afetados. Em adição foi avaliada a expressão diferencial de mRNA de ADA pela HU em monócitos destes pacientes, comparando tratados e não tratados e também avaliamos por citometria de fluxo a modulação de marcadores de superfície CD39, CD73 e CD26, pela HU. As análises estatísticas foram realizadas utilizando os softwares GenePop 3.4 para análises de associação, cálculo do $H W E$, GraphPad Prism 5, Arlequin para identificação de desequilíbrio de ligação, haplótipos, heterozigozidade e SAS 9.13 para associação dos haplótipos as características. Os resultados mostraram que os pacientes sob tratamento com HU apresentaram um aumento da expressão de mRNA de ADA, aumento da expressão de CD26 em monócitos e diminuição de CD39 em linfócitos. Sem alterações significativas em relação a CD73. Encontramos também um aumento da frequência do alelo T do SNP (rs1685103) presente no gene de ADORA 1 associado com pacientes afetados com síndrome torácica aguda. Apesar de não ter sido estatisticamente significante, concorda com dados da literatura. No gene ADORA 2B, verificamos associação do SNP 1007 C>T no desenvolvimento de STA indicando o alelo T como fator de risco e o alelo C para alterações ósseas. Para o SNP 968 G>T houve associação com alterações ósseas. Na análise haplotípica entre os SNPs 968 G>T e 1007 C>T encontramos associação dos haplótipos ht2 e ht3 com STA, como fator de risco, ht2 para hipertensão pulmonar. ht1 para priapismo, alterações ósseas e estenose/AVC. Os haplótipos formados pelos três SNPs 968 G>T, 1007 C > T e rs 16851030, encontramos associação entre ht1, ht3 e ht4 entre os afetados com priapismo, caracterizando-o como haplótipo de risco e também ht1 e ht6 associados à estenose/AVC. Concluímos, que a hidroxiuréia participa na modulação da expressão da adenosina deaminase, de CD26 em monócitos e CD39 em linfócitos. Além disso, mostrou-se a importância de sítios polimórfico presente no gene ADORA 2B e ADORA1 envolvido na fisiopatologia das manifestações clínicas da doença falciforme. Associações dos SNPs em ADORA 1 e ADA, devem ser melhor estudados em um número maior de pacientes. A determinação destes polimorfismos associados com diferentes características clínicas pode levar a um melhor entendimento dos processos fisiopatológicos da anemia falciforme, levando à identificação de pacientes de risco, possibilitando um manejamento racional dos mesmos, em termos de cuidados específicos, ou mesmo à determinação de alvos para o desenvolvimento de terapias alternativas. 


\title{
FILOGENIA DO COMPLEXO Drosophila buzzatii (GRUPO REPLETA): INFERÊNCIAS DE ANÁLISES MULTILOCUS MITOCONDRIAIS E NUCLEARES
}

\author{
Rafael Fransak Ferreira
}

Orientadora: Profa. Dra. Maura Helena Manfrin

Dissertação de Mestrado apresentada em 04/07/2011

O complexo Drosophila buzzatii (grupo repleta) compreende 13 espécies, divididas em três clusters, de acordo com o bandeamento observado nos cromossomos politênicos: cluster D. stalkeri, incluindo D. richardsoni e D. stalkeri, restrito às ilhas do Caribe e Flórida; cluster D. martensis, incluindo D. martensis, D. uniseta, D. venezolana e D. starmeri, encontrado em áreas desérticas da Colômbia e Venezuela; e cluster D. buzzatii, incluindo D. buzzatii, D. koepferae, D. antonietae, D. serido, D. gouveai, D. borborema e D. seriema, habitando regiões sazonalmente secas ao longo da diagonal de vegetação aberta da América do Sul. O presente estudo teve como objetivo inferir as relações filogenéticas entre as espécies do complexo D. buzzatii, dando ênfase ao cluster D. buzzatii, por meio de análises multilocus de genes mitocondriais (COI e COII) e nucleares (EF-1 $\alpha \mathrm{F} 1$, transformer e period). Nas hipóteses filogenéticas estabelecidas, as espécies do complexo $D$. buzzatii constituíram um grupo monofilético, composto por dois subgrupos monofiléticos, os clusters D. martensis e D. buzzatii, e um parafilético, o cluster D. stalkeri. As relações de parentesco entre as espécies do cluster D. buzzatii foram estabelecidas. Drosophila buzzatii ocupou a posição mais basal dentro do cluster D. buzzatii, estando proximamente relacionada à espécie D. koepferae. Drosophila antonietae ocupou uma posição intermediária em relação às espécies $D$. koepferae e D. serido, que representa o táxon irmão do ramo formado por D. gouveai, D. borborema e D. seriema, com D. gouveai ocupando uma posição mais basal em relação às espécies irmãs D. borborema e D. seriema. Foi detectada seleção purificadora como a principal força dirigindo a evolução dos genes nucleares transformer e period, para as espécies do complexo D. buzzatii. O gene mitocondrial COI, por sua vez, foi utilizado para estimar os tempos de divergência para as espécies do cluster D. buzzatii, revelando que o processo de diversificação do grupo iniciou-se no período Plioceno, provavelmente em decorrência de eventos de vicariância associados à elevação dos Andes, sendo também influenciado pelo avanço e retração da vegetação xerófita, nas flutuações climáticas do Pleistoceno.

\section{ANÁLISE DE POLIMORFISMOS DO GENE MC1R ASSOCIADOS A FENÓTIPOS HUMANOS DE PIGMENTAÇÃO NA POPULAÇÃO BRASILEIRA}

\author{
Leonardo Arduino Marano \\ Orientador: Prof. Dr. Celso Teixeira Mendes Junior \\ Dissertação de Mestrado apresentada em 05/07/2011
}

Dentre os genes conhecidos por influenciarem a variação normal de pigmentação de olhos, pele e cabelos em humanos, o gene MC1R (receptor de melanocortina 1) é o mais bem caracterizado até o momento. A atuação do MC1R ocorre pela produção de uma proteína transmembrana nos melanócitos, responsável pela regulação da produção de melanina nos mesmos. Sabe-se que a atuação do MC1R determina a proporção entre eumelanina (coloração castanha/ preta) e feomelanina (coloração amarela/vermelha) presente nos melanócitos. O presente trabalho tem como objetivo analisar os SNPs conhecidos do gene MC1R com o propósito de se avaliar a influência da diversidade deste gene em características como a presença de sardas e variação da pigmentação dos olhos, pele e cabelos em humanos. Foram analisados 29 SNPs conhecidos da região codificadora do gene MC1R em 131 indivíduos da região de Ribeirão Preto, SP. A extração do DNA foi feita pela técnica de salting-out. A região codificadora do gene MC1R (951pb) foi amplificada em uma única reação de PCR, a qual foi sequenciada em um analisador genético ABI-PRISM 310 por eletroforese capilar, utilizando-se os mesmos primers empregados para a amplificação. Dos 29 SNPs avaliados, 22 deles mostraram variação nas amostras estudadas, sendo que metade deles demonstrou estar associados a características de pigmentação. Observou-se um conjunto de SNPs associados claramente à fenótipos relacionados à feomelanina (+1645 A, +1858 T e +2260 C), enquanto outros se relacionam à ocorrência de eumelanina $(+1558 \mathrm{G},+2322 \mathrm{G},+2346$ A). A reconstrução de haplótipos gerou 31 haplótipos, sendo que quatro deles estavam associados à pele escura e dois outros tinham frequências significativamente baixas em pele clara. Um haplótipo se associou a olhos verdes, enquanto dois outros tiveram associação com olhos castanho escuros. Cores escuras de cabelo se relacionaram à seis haplótipos distintos enquanto cabelos ruivos estavam associados à dois e um outro associado à cabelos loiros. Por fim, a ocorrência de sardas foi significativamente relacionada à três haplótipos. O presente trabalho apresenta associações significativas entre SNPs individuais e pigmentação de olhos, cabelos e pele, sendo que nossos dados confirmam que tal gene também desempenha papel relevante na variação de pigmentação na população brasileira. 


\title{
UTILIZAÇÃO DE ANÁLISE BIOINFORMÁTICA E VALIDAÇÃO POR PCR QUANTITATIVA EM TEMPO REAL NA IDENTIFICAÇÃO DA INDUÇÃO TRANSCRICIONAL DOS FATORES DE TRANSCRIÇÃO E2F1 E E2F4 EMM LINHAGENS DE GLIOBLASTOMA"
}

\author{
Flávia Sacilotto Donaires \\ Orientadora: Profa. Dra. Elza Tiemi Sakamoto Hojo \\ Dissertação de Mestrado apresentada em 14/07/2011
}

O emprego da metodologia de microarranjos no estudo do câncer tem permitido a identificação de genes com alterações em seus perfis de expressão, os quais estão direta ou indiretamente envolvidos na etiologia dessa doença. O crescente número de publicações de experimentos de expressão gênica em repositórios de dados de microarranjos demonstra que, em geral, a limitação não está na quantidade ou qualidade desses experimentos, mas no processamento desses dados. Dessa forma, há a necessidade de desenvolver metodologias de bioinformática que sejam capazes de analisar tais perfis de forma integrada, incluindo no contexto da análise, dados provenientes de outros experimentos. O desenvolvimento do câncer tem sido associado principalmente a distúrbios nos mecanismos de controle do ciclo celular, cujas vias são dependentes de uma maquinaria transcricional e de seus elementos regulatórios; entre estes últimos, os fatores de transcrição (FTs) têm sido estudados como potenciais alvos para a terapia molecular. No presente trabalho, um conjunto de dados de microarranjos realizados a partir de amostras de glioblastoma foi obtido em repositórios públicos (GEO e ArrayExpress). O teste estatístico SAM foi aplicado aos dados e os genes diferencialmente expressos (FDR $£$ 0,05), induzidos em glioblastoma (1.830 genes), foram submetidos a uma análise de associação a FTs (programa FatiGO+), a qual associou os FTs $H N F 1 A, I R F 7$ e $E 2 F$ ( $\mathrm{p} £ 0,05$ ) aos genes induzidos. Adicionalmente, a lista de genes foi submetida a uma análise de associação a um banco de dados de assinaturas transcricionais do software TBrowser, extraídas de diversos experimentos de microarranjos do GEO. Como resultado, 7.910 assinaturas foram associadas ( $\mathrm{p} £ 0,01$ ), sendo que as cem primeiras também foram relacionadas a FTs por meio de ferramentas disponibilizadas no próprio TBrowser. Os FTs $E 2 F 1$ e $E 2 F 4$ foram associados a mais de $80 \%$ das assinaturas analisadas. Dessa forma, ambas as análises apontaram o FT $E 2 F$, mais especificamente $E 2 F 1$ e $E 2 F 4$, como associados à lista inicial de genes fornecida pelo SAM. A expressão de E2F1 e E2F4 foi avaliada por meio da técnica de RT-PCR quantitativa em tempo real em amostras de RNA de sete linhagens de glioblastoma (T98, U251, U138, U87, U343, MO59J e MO59K). Interessantemente, ambos os genes foram apontados como superexpressos em todas as linhagens, a maioria com significância estatística. A família de FTs $E 2 F$ apresenta papéis importantes no controle da proliferação celular e apoptose. Alguns membros atuam como oncogenes, e outros, como genes supressores de tumor, dependendo do contexto molecular nos quais se encontram. Muitos trabalhos da literatura têm apontado a importância desses FTs, especialmente $E 2 F 1$, no processo de tumorigênese. Com base nos resultados obtidos no presente trabalho, o status de expressão (indução) de E2F1 e E2F4 é provavelmente associado ao glioblastoma. Esses FTs podem influenciar a expressão de uma série de genes cruciais, frequentemente alterados nessa doença, o que ainda requer um estudo mais detalhado, visando à validação desses FTs como biomarcadores, ou até mesmo como alvos moleculares que possam ser empregados no estabelecimento de novas modalidades de terapias.

\section{OS MÓdULOS DE SINALIZAÇ̃̃o INSULÍNICA (IIS) E DE HIPÓXIA AO LONGO DO DESENVOLVIMENTO LARVAL DE OPERÁRIA E RAINHA DE ABELHAS Apis mellifera}

\author{
Sérgio Vicente de Oliveira \\ Orientador: Prof. Dr. Klaus Hartmann Hartfelder \\ Tese de Doutorado apresentada em 15/07/2011
}

As abelhas Apis mellifera sao insetos eussociais caracterizados pela presença de duas castas fêmeas, rainha e operaria, que apresentam diferenças morfológicas, fisiológicas e comportamentais necessárias para garantir a eficiência na execução das tarefas reprodutivas (rainha) e manutenção da colméia (operarias). A expressão de fenótipos alternativos em abelhas não e determinada por diferenças genéticas, mas por uma sucessão diferenciada de eventos neuroendócrino, endócrino e transcricional desencadeados em resposta ao tipo de alimentação oferecida as larvas durante o período de alimentação. O sequenciamento do genoma de abelhas permitiu o estudo de novas vias de sinalização envolvidas no processo de diferenciação de castas, dentre as quais a via insulínica (IIS) e a via de hipoxia. Ambos os módulos de sinalização são conservados entre os metazoarios, sendo a via IIS relacionada a adaptação do organismo as condições 
nutricionais e a via de hipoxia relacionada a resposta aos níveis de oxigênio. Trabalhos recentes colocaram a via de IIS em uma posição de destaque na regulação do processo de diferenciação de castas em abelhas, principalmente com relação aos níveis de transcrição de seus genes durante as fases de desenvolvimento larval e a experimentos de knockdown dos genes para o substrato do receptor de insulina e do alvo de rapamicina. Para a via de hipoxia as informações existentes se concentraram nas diferenças no metabolismo das duas castas. Neste trabalho, a partir de analises por RT-qPCR para os genes codificadores dos receptores de insulina ( $A m \mathrm{InR} 1$ e $A m \mathrm{InR} 2)$ e dos peptídeos insulínicos (AmILP1 e $A m I L P 2)$ observou-se que o peptídeo insulínico 2 foi a forma predominantemente transcrita para ambas as castas e que os receptores de insulina 1 e 2 apresentaram padrões semelhantes de expressão, indicando o provável compartilhamento de reguladores no controle de suas transcrições. O tratamento com dsRNA para os genes AmInR1, AmInR2, AmILP1 e AmILP2 não foi eficaz no silenciamento especifico dos genes alvos, no entanto evidenciou uma possível regulação cruzada entre AmILP1 e AmILP2. A quantificação dos açucares, na hemolinfa das larvas tratadas com dsRNA especificos para os genes da via IIS, apresentou inesperadamente maiores níveis de glicose do que trealose, podendo ser reflexo do alto consumo de energia e crescimento acentuado na fase analisada. Adicionalmente, foram identificados, a partir dos ortologos de Drosophila melanogaster e Resumo mamíferos, os genes envolvidos na sinalização por hipoxia em Apis mellifera, Amsima, Amtango e Amfatiga. As analises por RT-qPCR desses genes demonstraram padrão de regulação casta especifica durante o desenvolvimento larval, com os níveis de transcrição para os três genes maiores em operarias do que em rainhas, indicando uma hipoxia endógena em operarias. Os resultados desse trabalho, alem de estenderem os dados já existentes para a via IIS, foram os primeiros a relacionarem a via de sinalização por hipoxia ao desenvolvimento de abelhas, sugerindo interação com a via IIS/TOR e com a sinalização via hormônios e lançando, portanto, a sinalização por hipoxia como um possível elemento regulador do processo de diferenciação de castas em abelhas.

\title{
ANÁLISE DA EXPRESSÃO GÊNICA DURANTE A DIFERENCIAÇÃO OSTEOGÊNICA DE CÉLULAS MESENQUIMAIS ESTROMAIS DA MEDULA ÓSSEA DE PACIENTES PORTADORES DE OSTEOGÊNESE IMPERFEITA
}

\author{
Carla Martrins Kaneto \\ Orientador: Prof. Dr. Wilson Araújo da Silva Junior \\ Tese de Doutorado apresentada em 29/07/2011
}

A osteogênese imperfeita (OI) é caracterizada como uma desordem genética na qual uma osteopenia generalizada leva a baixa estatura, fragilidade óssea excessiva e deformidades ósseas graves. As células mesenquimais estromais multipotentes (CTMs) são precursores presentes na medula óssea adulta capazes de se diferenciar em osteoblastos, adipócitos e mioblastos que passaram a ter grande importância como fonte terapia celular. O objetivo do presente estudo foi analisar o perfil de expressão gênica durante a diferenciação osteogênica a partir de células mesenquimais estromais multipotentes da medula óssea obtidas de pacientes diagnosticados com Osteogênese Imperfeita e de indivíduos controle. Foram coletadas amostras de três indivíduos normais e cinco amostras de pacientes portadores de Osteogênese Imperfeita. As células mononucleares (CMN) foram isoladas para a obtenção de células mesenquimais que foram expandidas até a terceira passagem quando iniciou-se o estímulo para diferenciação osteogênica. Também foram realizadas análises para contagem de CFU-F e para quatro das cinco amostras de pacientes portadores de OI, o número de CFU-F observado foi inferior ao geralmente encontrado para amostras de doadores normais. Foram coletadas células para análises de imunofenotipagem celular por citometria de fluxo e o RNA foi extraído originando a amostra denominada T0. As garrafas restantes tiveram suas células estimuladas para diferenciação osteogênica. Após um dia em cultura com estímulo, mais uma garrafa teve o RNA de suas células extraído (T1), e o mesmo procedimento foi realizado nos dias 2 (T2), 7 (T7), 12 (T12), 17 (T17) e 21 (T21). Todas as amostras demonstraram possuir potencial de diferenciação in vitro em osteoblastos e adipócitos. A imunofenotipagem de células mesenquimais foi realizada e as amostras de todos os pacientes apresentaram perfil imunofenotípico compatível com trabalhos anteriores. Foram identificadas mutações nos genes COL1A1 e/ou COL1A2 responsáveis pelo desenvolvimento da doença para quatro dos cinco pacientes avaliados. Para o paciente portador de Osteogênese Imperfeita e Síndrome de Bruck a região codificadora do gene PLOD2 também foi sequenciada, porém não foram encontradas mutações. A análise da expressão gênica foi realizada pela técnica de microarranjos e foram identificados vários genes com expressão diferencial. Alguns genes com importância fundamental na diferenciação osteoblástica apresentaram menor expressão nas amostras dos pacientes portadores de OI, sugerindo um menor comprometimento das CTMs desses pacientes com a linhagem osteogênica. Outros genes também tiveram sua expressão diferencial confirmada por PCR em Tempo Real. Foi observado um aumento na expressão de genes relacionados a adipócitos, sugerindo um 
aumento da diferenciação adipogênica em detrimento à diferenciação osteogênica. A expressão das variantes do gene PLOD2 mostrou-se diferencial entre amostras normais, de OI e do paciente portador de Síndrome de Bruck. Também foi evidenciada uma expressão diferencial do microRNA 29b, um microRNA com papel estabelecido durante a diferenciação osteogênica, sugerindo um mecanismo de regulação dependente da quantidade de RNAm do seu gene alvo, o COL1A1.

\title{
AVALIAÇÃO DA PROPORÇÃO SEXUAL DE EMBRIÕES DESENVOLVIDOS in vitro E PROGÊNIE A CAMPO DE TOUROS JOVENS
}

\author{
Fernanda Prado Elias \\ Orientador: Prof. Dr. Raysildo Barbosa Lôbo \\ Tese de Doutorado apresentada em 01/08/2011
}

Um dos grandes problemas que afetam a produção in vitro de embriões é a variação entre touros em relação à fertilidade e o maior nascimento de embriões do sexo masculino. Muitos fatores podem alterar a razão de 1:1 entre os gêneros tanto na produção in vitro de embriões, como no método de Inseminação Artificial. No sentido de tentar alterar esta proporção sexual in vitro, estudamos em um primeiro momento, a variação entre touros no desenvolvimento de embriões machos e fêmeas, distribuídos nas fases de blastocisto jovem, blastocisto, blastocisto expandido e blastocisto eclodido, bem como, a proporção macho: fêmea em relação a fase do blastocisto. Para tanto, oócitos foram coletados de ovários oriundos de matadouro e maturados em meio de maturação em incubadora por 24h. Espermatozóides viáveis de 17 touros do Programa de Melhoramento Genético da Raça Nelore, obtidos por centrifugação em gradiente de Percoll, foram utilizados para Fecundação in vitro. Após $12 \mathrm{~h}$, os supostos zigotos foram cultivados em meio de cultivo e células do cumulus em incubadora. Ao sétimo dia após a fertilização in vitro foi feita a seleção dos blastocistos viáveis que foram sexados com a utilização de primers Y-específico bovino e autossômico bovino, com visualização dos fragmentos amplificados em gel de agarose. Posteriormente, para obtenção de maior conhecimento a respeito dos animais testados, coletamos dados de progênie a campo destes animais e verificamos a proporção sexual de seus filhos nascidos pelo método da inseminação artificial, monta natural e possíveis correlações com características quantitativas. Diferenças entre touros foram observadas em relação à proporção dos sexos para as fases de blastocisto inicial e blastocisto expandido. Não foi observado desvio da proporção sexual em relação ao touro utilizado na produção in vitro de embriões e progênie a campo. Nosso dados sugerem que é possível alterar a proporção macho:fêmea em sistemas de produção in vitro de embriões pela seleção do estágio do blastocisto para transferência, e ainda, sugerem que touros apresentam variação em relação ao desenvolvimento in vitro de embriões machos e fêmeas de acordo com o estágio do blastocisto.

\section{ANÁLISE DE GENES DA FAMÍLIA MTN3/SALIVA EXPRESSOS NO PISTILO DE Nicotiana tabacum L.}

\section{Marcella de Francisco Amorim}

Orientadora: Profa. Dra. Maria Helena Souza Goldman

Dissertação de Mestrado apresentada em 10/08/2011

O pistilo é um órgão de importância central na reprodução de plantas, sendo responsável pela recepção, reconhecimento, seleção e aceitação de grãos de pólen. Muitos genes preferencialmente ou especificamente expressos no pistilo podem estar relacionados à reprodução. TOBC023B06, um clone identificado na biblioteca de cDNA de estigma/estilete de Nicotiana tabacum (TOBEST), foi previamente descrito com uma expressão específica no estigma/estilete. Análises in silico indicaram que este pertence à família MtN3/saliva de proteínas de transmembrana. Em plantas, algumas proteínas MtN3/saliva foram descritas (RPG1, Os8N3, NEC1 e SAG29) e todas estão de alguma forma associadas à reprodução. Apesar desses estudos, pouco se conhecia sobre a função dessas proteínas até recentemente e, assim, o objetivo deste trabalho foi estudar TOBC023B06 e outras proteínas MtN3/saliva expressas no pistilo de N. tabacum. Para entender a função de 23B06, plantas transgênicas de $N$. tabacum (super-expressando e silenciando 23B06) foram obtidas via Agrobacterium. Plantas de super-expressão apresentaram um estilete alongado (T0) e análises da segunda geração (T1) revelaram plântulas com retardo no crescimento em condições normais e hipersensibilidade à alta salinidade. Plantas silenciadas não apresentaram nenhum fenótipo visível (T0), entretanto sementes da planta com o menor nível de expres- 
são de 23B06 apresentou dificuldades na germinação. Experimentos de expressão transiente (35S::TOBC023B06-eGFP) em folhas e protoplastos indicaram uma localização em membrana plasmática para a proteína 23B06. Análises in silico da proteína 23B06 revelaram a presença de 7 regiões de domínios transmembrânicos e uma porção C-terminal longa e localizada dentro da célula. Além disso, uma sequência genômica parcial correspondendo ao 23B06 foi obtida no Sol Genomics Network (Blastn), revelando 6 éxons e uma região promotora com elementos cis-regulatórios envolvidos com a resposta ao ABA e também alguns elementos necessários para expressão em endosperma. Esses elementos também foram encontrados no promotor do seu ortólogo em Arabidopsis (SAG29), o qual possui elevada expressão durante o desenvolvimento da semente e responde a tratamentos com ABA. Além de TOBC023B06, seis contigs/genes codificando proteínas MtN3/saliva foram encontrados no TOBEST e uma busca por sequências homólogas foram feitas nos genomas de Arabidopsis thaliana e Populus trichocarpa. Sequências de aminoácidos dessas proteínas MtN3/saliva foram alinhadas pelo programa MAFFT e uma árvore filogenética foi construída pelo PhyML3(aLTR). Cinco grupos de possíveis ortólogos entre essas três espécies foram definidos e genes homeólogos (TOBC023B06 e TOBC047C06; TOBC48E05 e TOBC17D07) foram encontrados em N. tabacum. Cinco genes de Arabidopsis, identificados como ortólogos de proteínas MtN3/saliva de N. tabacum, possuem alta expressão em estruturas reprodutivas: estames, pólen, pistilo e sementes/embrião. Em Populus, dados de expressão para alguns genes foram também encontrados e revelaram altas expressões em inflorescências. Com relação às sequências de N. tabacum, análises de RT-qPCR demonstraram que TOBC017D07/TOBC048E05 é preferencialmente expresso em ovários e TOBC052F12 é expresso amplamente em todos os órgãos analisados. Além disso, realizamos novamente a análise de TOBC023B06, visando detectar a expressão desse gene separada do seu homeólogo. Os dados obtidos revelaram que, na verdade, TOBC023B06 possui elevadas expressões não apenas em estigma/estilete, mas também em pétalas e estames. Por outro lado, o seu homeólogo (TOBC047C06) possui expressão específica no estigma/estilete. Apesar dessas diferenças nos padrões de expressão dos homeólogos, ambos os genes são regulados durante o desenvolvimento do estigma/estilete, sendo mais expressos nos últimos estádios em direção a antese. Considerando a função de transportadores de açúcares estabelecida recentemente para proteínas da família MtN3/saliva, e a expressão destes genes em estigma/estilete, que coincide com a produção do exudato rico em açúcares, é possível propor que proteínas MtN3/saliva do pistilo estão envolvidas com o transporte de açúcares para o exudato.

\title{
ANÁLISE DE MARCADORES GÊNICOS DE ESTRESSE GENOTÓXICO EM FIBROBLASTOS HUMANOS NORMAIS E CÉLULAS DE GLIOBLASTOMA
}

\author{
Gustavo Nóriz Berardinelli \\ Orientadora: Profa. Dra. Elza Tiemi Sakamoto Hojo \\ Dissertação de Mestrado apresentada em 24/08/2011
}

Muitos genes têm sido indicados como responsivos ao estresse genotóxico, mas devido à necessidade de validação, a busca por marcadores gênicos continua. Vários genes são relacionados ao sistema ubiquitina-proteassomo (UPS), o qual é responsável pela remoção seletiva de proteínas, sendo que falhas no UPS têm sido relacionadas a doenças neurodegenerativas e ao câncer. Assim, o presente trabalho teve como objetivo a busca e confirmação de marcadores gênicos de resposta ao estresse genotóxico, por meio do estudo da expressão transcricional e protéica dos genes ERN1, EIF2AK3, GADD153 e TRAF2, visando à confirmação das respostas em linhagens de fibroblastos (GM07492A e AS405) e de glioblastoma (U87MG), sob tratamentos com peróxido de hidrogênio $\left(\mathrm{H}_{2} \mathrm{O}_{2}\right)$ e Bleomicina (Blm). Foram utilizados o Ensaio Cometa, a análise de expressão gênica transcricional por qPCR em tempo real e de expressão gênica ao nível protéico (imunofluorescência). Os resultados mostraram que os tratamentos empregados foram capazes de induzir danos no DNA, sendo que a sensibilidade ao tratamento e a capacidade de recuperação das linhagens foi variável dependendo do agente testado. A análise de expressão gênica mostrou que GM07492A apresentou indução dos genes ERN1 e GADD153 após tratamento com $\mathrm{H}_{2} \mathrm{O}_{2}$ (resposta precoce, zero e $2 \mathrm{~h}$ ) e Blm (durante todo pós-tratamento). A linhagem AS405 exibiu indução de ERN1 e GADD153 para $\mathrm{H}_{2} \mathrm{O}_{2}$, enquanto que para Blm foram induzidos os genes EIF2AK3 e GADD153. Para

U87MG, a indução de EIF $2 A K 3$ pelo $\mathrm{H}_{2} \mathrm{O}_{2}$ ocorreu de modo tardio, enquanto GADD153 mostrou-se induzido após ambos os tratamentos. A proteína ERN1 apresentou expressão discreta e pontual, inclusive nos pontos onde não houve indução transcricional, indicando uma expressão basal. Essa proteína se expressou em GM07492A no tratamento com Blm em zero hora, diferentemente de AS405. Para U87MG tratada com $\mathrm{H}_{2} \mathrm{O}_{2}$ observou-se discreta expressão de ERN1, sendo mais evidente para Blm. Quanto à proteína GADD153, esta foi expressa em fibroblastos nos vários tempos analisados. No entanto, U87MG mostrou expressão nuclear apenas nas células tratadas, sendo mais evidente para $\mathrm{H}_{2} \mathrm{O}_{2}$ comparativamen- 
te à Blm. Assim, as alterações observadas nos perfis de expressão gênica são compatíveis com a indução de danos no DNA, indicando o envolvimento de genes do UPS nas respostas celulares ao estresse genotóxico. Em conjunto, os resultados estimulam uma avaliação mais detalhada desses genes como marcadores de resposta ao estresse e evidencia a sua importância no cenário da via UPS.

\title{
EFEITOS DAS PRÓPOLIS VERDE E DE ABELHA TUBI NA CARCINOGÊNESE EXPERIMENTAL DO CÂNCER DE CÓLON EM RATOS WISTAR
}

\author{
Ana Paula Farnesi \\ Orientador: Prof. Dr. Sérgio Britto Garcia \\ Tese de Doutorado apresentada em 29/08/2011
}

O presente trabalho teve por objetivo avaliar a atividade preventiva da própolis verde e própolis da abelha Scaptotrigona sp (tubi) na prevenção do câncer de cólon em ratos Wistar. Os marcadores imuno - histoquímicos estudados foram: (i)PCNA, COX II, CASPASE III. Elevados níveis de expressão de PCNA, COX-2 e menor expressão do receptor Caspase-3 foram observados, com diferença estatisticamente significante, nos grupos que foram tratados com o carcinógeno Dimetilhidrazina e nos grupos que receberam tratamento com própolis verde, demonstrando assim uma importância destes na carcinogênese colônica. Nos grupos tratados com Scaptotrigona sp (tubi) houve redução da expressão de COX-2 e aumento de CASPASE III, ambos com significância estatística. A partir dos dados do presente estudo experimental, é possível sugerir que o tratamento com a própolis da abelha Scaptotrigona sp (tubi) pode reduzir a susceptibilidade para o câncer de cólon em ratos através da indução de efeitos anti-inflamatórios na mucosa colônica e da atenuação dos efeitos proliferativos nas células pré-neoplásicas.

\section{DESENVOLVIMENTO E CARACTERIZAÇÃO DE MARCADORES MICROSSATÉLITES DE Scaptotrigona aff depilis (Hymenoptera, Apidae, Meliponini)}

\author{
Camila Calixto Moreira Dias \\ Orientador: Prof. Dr. Ademilson Espencer Egea Soares \\ Dissertação de Mestrado apresentada em 06/09/2011
}

As abelhas da tribo Meliponini são conhecidas como abelhas indígenas sem ferrão. São encontradas em áreas tropicais e subtropicais do mundo e estão entre os principais polinizadores da flora brasileira, no entanto, a maioria das espécies estão seriamente ameaçadas de extinção devido a fragmentação dos ecossistemas onde vivem, causados principalmente pelas queimadas e desmatamento. Scaptotrigona aff depilis é uma espécie de abelha indígena sem ferrão que vive em ocos de árvores com colônias bastante populosas. As operárias são de porte pequeno e possuem uma coloração preta fosca. No Brasil, elas são encontradas no Rio Grande do Sul, Paraná, Mato Grosso do Sul, São Paulo e Minas Gerais. Assim como para a maioria dos meliponíneos os estudos populacionais para esta espécie são muito escassos, fazendo-se necessário a ampliação desses estudos para uma melhor compreensão da dinâmica populacional da espécie para futuras estratégias de manejo e conservação. Este trabalho teve como objetivo principal desenvolver um conjunto de marcadores microssatélites que possam ser úteis para futuros estudos populacionais. Foi desenvolvido um conjunto de 20 pares de primers microssatélites, utilizando a técnica de biblioteca genômica enriquecida. Esses primers foram caracterizados em 90 abelhas de nove ninhos naturais coletados de sete regiões (Londrina-PR; Cornélio Procópio-PR; Piracicaba-SP; Ribeirão Preto-SP; Jardinópolis-SP Franca-SP e Uberlândia-MG). Dos 20 pares de primers desenhados e sintetizados, 17 tiveram sucesso na amplificação. O número de alelos por loco variou de 3 a 11 (média de 6,23). A heterozigosidade esperada variou de 0,345 a 0,863 e a heterozigosidade observada variou de 0,226 a 0,938 . Os locos apresentaram alta probabilidade de exclusão de paternidade. $\mathrm{O}$ índice de diversidade genética dos locos $(6,23)$ foi maior que os relatados em muitas espécies de abelha indígena sem ferrão. Não foram detectados indícios significativos de ligação entre os locos desenvolvidos. $\mathrm{O}$ teste de transferibilidade entre $S$. aff depilis e outras espécies de meliponíneos, demonstrou que as sequências que flanqueiam as regiões microssatélites são conservadas, uma vez que 10 pares de primers amplificaram em pelo menos quatro das sete espécies testadas. A diversidade alélica $(2,4)$ nos ninhos estudados ficou abaixo do observado na litera- 
tura, este fato ocorreu devido ao baixo número de indivíduos amostrados por região. As estatísticas F mostraram que não ocorre endogamia entre os ninhos (Fis=-0,2410) e que eles estão estruturados (Fst=0,3810). Os resultados obtidos neste trabalho mostram que os primers desenvolvidos para a $S$. aff depilis são bem informativos e adequados para futuros estudos de distribuição da diversidade genética, estrutura populacional, agregação de ninhos, conservação e manejo, estudos de filogeografia e estudos de parentesco.

\title{
ALTERAÇÕES NA CINÉTICA DE REPARO DO DNA E NOS PERFIS DE EXPRESSÃO DE GENES DE RESPOSTA AO ESTRESSE EM LINFÓCITOS DE PORTADORES DA DOENÇA DE ALZHEIMER
}

\author{
Giovana da Silva Leandro \\ Orientadora: Profa. Dra. Elza Tiemi Sakamoto Hojo \\ Dissertação de Mestrado apresentada em 13/09/2011
}

A Doença de Alzheimer (DA) é uma demência senil neurodegenerativa crônica, que causa um grande impacto na saúde pública. Apesar de o estresse oxidativo ter sido largamente associado ao processo de envelhecimento e à patogênese das doenças neurodegenerativas (incluindo DA), a literatura sobre o papel do estresse oxidativo no desenvolvimento da DA ainda é escassa assim como para seus fatores de risco. O presente trabalho teve o objetivo avaliar se os linfócitos de pacientes com DA apresentam alterações nos níveis de expressão de alguns genes associados à respostas ao estresse, tais como SOD1, TP53, ATM, ATR, FEN1, FANCG, CDKN1A e MTH1; além de ADAM10 e ADAM17, associados diretamente a patologia. Além disso, foi proposto também avaliar os níveis de danos no DNA e a cinética de reparo dos linfócitos desses indivíduos quando tratados com peróxido de hidrogênio $\left(\mathrm{H}_{2} \mathrm{O}_{2}\right)$, um agente indutor de danos no DNA. As amostras de sangue foram coletadas de pacientes com DA (idade entre 65 a 80 anos) e indivíduos idosos de mesma idade para analisar a expressão gênica protéica por Western blot $(n=6)$ e a expressão transcricional por PCR quantitativa em tempo real $(n=7)$. O ensaio cometa foi realizado para analisar os danos no DNA e a cinética de reparo em linfócitos de pacientes com DA ( $n=8)$, indivíduos idosos de mesma idade $(n=8)$ e jovens sadios ( $n=5$; faixa etária entre 18 e 28 anos), cultivados por $48 \mathrm{~h}$ e tratados com $\mathrm{H}_{2} \mathrm{O}_{2}$ por $1 \mathrm{~h}$, e analisados em diferentes tempos de recuperação: 0; 0,5; 2 e 6 horas. A análise da expressão gênica por PCR em tempo real mostrou que o gene $F A N C G$, cuja função está relacionada ao controle do ciclo celular e ao reparo do DNA, estava induzido em portadores de DA; o gene CDKN1A, envolvido na resposta a danos no DNA, também se apresentou induzido em portadores de DA. No entanto, não foram observadas alterações com diferenças significativas nos perfis transcricionais dos genes ATM, ATR, FEN1 e MTH1 entre portadores de DA e controles. Em relação às proteínas analisadas, foi observada uma sutil diminuição nos níveis da SOD1 em DA, mas não houve diferenças para ADAM10 e ADAM17. Além disso, observou-se um aumento da expressão da proteína TP53, enquanto a análise da forma fosforilada (serina 15) apresentou baixos níveis de indução. Esses resultados são compatíveis com a ausência de diferença nos níveis de expressão dos genes $A T M$ e ATR. Em relação à análise de indução de danos no DNA e à cinética de reparo, os resultados mostraram diferenças significativas entre os portadores de DA e os controles, o que pode sugerir que os mecanismos envolvidos no processamento do dano oxidativo são diferentes na patologia de Alzheimer quando comparados ao processo de envelhecimento per se. Finalmente, os resultados obtidos sustentam a hipótese de que as vias de reparo do DNA podem estar comprometidas na DA. Além disso, foi mostrado que linfócitos do sangue periférico humano podem refletir pelo menos algumas das alterações associadas à doença, o que incentiva maiores investigações nessas células que possam fornecer biomarcadores com potencial para contribuir na caracterização da DA.

\section{ESTUDOS GENÉTICOS DA ESPÉCIE FLORESTAL Cariniana estrellensis (Raddi) Kuntez: DIVERSIDADE, SISTEMA DE CRUZAMENTO E FLUXO GÊNICO CONTEMPORÂNEO}

\author{
Marcela Corbo Guidugli \\ Orientadora: Profa. Dra. Ana Lilia Alzate Marin \\ Tese de Doutorado apresentada em 16/09/2011
}

Cariniana estrellensis (Raddi) Kuntez (Lecythidaceae), popularmente conhecida como jequitibá branco, é uma espécie arbórea climácica neotropical cuja sobrevivência encontra-se ameaçada devido aos processos de degradação de seus ambientes naturais e exploração indevida. Visando contribuir para a conservação in situ e ex situ deste recurso 
genético, o objetivo deste trabalho foi investigar a diversidade genética, o sistema de reprodução, a estrutura genética espacial e o fluxo gênico contemporâneo de C. estrellensis em um pequeno remanescente florestal ( 8 ha) localizado na Região de Ribeirão Preto - SP (município de Cravinhos), usando como ferramenta de análise um conjunto de nove marcadores microssatélites (SSR) desenvolvidos para a espécie. Todas as árvores adultas reprodutivas (30) e regenerantes (39) existentes no referido fragmento foram mapeadas e tiveram tecidos foliares amostrados para as análises genéticas. Sementes de polinização natural foram também aleatoriamente coletadas em algumas destas árvores adultas durante dois eventos reprodutivos, obtendo-se um total de 644 progênies. Através das análises SSR constatou-se que todas as gerações de C. estrellensis apresentaram altos níveis de diversidade genética e ausência de endogamia, evidenciando a alogamia da espécie. Em concordância, as taxas de cruzamentos (tm) estimadas para os dois eventos reprodutivos não diferiram estatisticamente da unidade, permitindo afirmar que C. estrellensis é uma espécie perfeitamente alógama, com indícios de mecanismos de auto-incompatibilidade. Estimativas da correlação de paternidade $(r p(m)$ (evento 1$)=0,121$ e rp $(m)($ evento $2)=0,145$ ) e do coeficiente de coancestralidade médio dentro de progênies (Èxy (evento 1) $=0,140$ e Èxy (evento 2) $=0,141$ ) indicaram a ocorrência de pequenos desvios de cruzamentos aleatórios na população de C. estrellensis. O número efetivo de doadores de pólen estimado foi mais alto entre frutos de uma mesma árvore (10,20(evento 1); 10,31(evento 2) ) do que dentro de um mesmo fruto (1,33(evento 1); 1,17(evento 2)). Os resultados também revelaram que não existe estruturação genética espacial na população de $C$. estrellensis. As análises de parentesco em C. estrellensis revelaram distâncias médias curtas do fluxo de pólen dentro do fragmento tanto para as progênies $(69,95 \pm 60 \mathrm{~m}$ (evento 1); 112,02 $\pm 94 \mathrm{~m}$ (evento 2)) quanto para os regenerantes $(146,94 \pm 98 \mathrm{~m})$. Além disso, os resultados das análises de parentesco nos regenerantes apontaram ausência de imigração de sementes na população e indicaram que a taxa de imigração de pólen realizado (variando entre $53 \%$ e $62 \%$ ) foi maior que as taxas de imigração de pólen efetivo (variando entre $23,5 \%$ e $37 \%$ ) para os dois eventos reprodutivos estudados. Os altos níveis de imigração de pólen detectados no fragmento em estudo sugeriram que a população de $C$. estrellensis não está isolada reprodutivamente, o que pode ser essencial para prevenir perdas de diversidade genética da espécie, garantindo sua sobrevivência em longo prazo. Em termos gerais, a população estudada mostrou resiliência aos efeitos adversos da fragmentação e potencial para fins de conservação in situ e ex situ.

\title{
Ginecologia e Obstetrícia
}

\section{AVALIAÇÃO LONGITUDINAL DOS PARÂMETROS DOPPLERVELOCIMÉTRICOS MATERNO-FETAIS E DO NITRITO PLASMÁTICO MATERNO AO LONGO DA GESTAÇÃO}

\author{
Salim Demetrio Jorge Neto
}

Orientador: Prof. Dr. Ricardo de Carvalho Cavalli

Dissertação de Mestrado apresentada em 05/08/2011

O principal regulador do tônus vascular é o óxido nítrico (NO). No endotélio, este gás é sintetizado pela óxido nítrico-sintase endotelial (eNOS) através da conversão do aminoácido L-arginina e oxigênio em L-citrulina e NO, promovendo relaxamento muscular e vasodilatação.Uma maneira de se avaliar a atividade da eNOS se da pela análise dos produtos de degradação relacionados à via do NO pois o mesmo possui curta meia-vida e suas pequenas concentrações dificultam a avaliação quantitativa da sua produção in vivo nos tecidos. Sendo assim, a análise das concentrações plasmáticas dos principais produtos da oxidação do NO (nitritos e nitratos) é mais comumente utilizada. Neste sentido, o estudo proposto pretende a avaliar um biomarcador (nitrito plasmatico) mais apropriado para análise da atividade da eNOS ao longo da gravidez. Além disso, como o NO atua promovendo o relaxamento dos vasos, avaliamos o fluxo úteroplacentário, utilizando avaliação dopplervelocimétrica de vasos maternos (artérias uterinas) e fetais (artérias cerebral média e umbilical). Os parâmetros dopplervelocimétricos avaliados foram o pico de velocidade sistólica (PVS), o pico de velocidade diastólica (PVD), a relação sístole sobre diástole (S/D), o índice de pulsatilidade (IP) e o índice de resitência (IR). Foram selecionadas 33 gestantes saudáveis avaliadas no primeiro (11-14 semanas), segundo (20-24 semanas) e no terceiro trimestre (34-36 semanas) da gravidez. Em cada visita médica agendada, foi realizada avaliação dopplervelocimétrica de vasos maternos e fetais, e coleta de sangue venoso $(15 \mathrm{~mL})$ materno para dosagem do nitrito plasmático, utilizando técnica de quimiluminescência.Observamos queda dos índices dopplervelocimétricos das artérias uterinas ao longo da gestação. Para os parâmetros dopplervelocimétricos fetais,observamos valores estáveis para os índices da artéria cerebral média e queda dos índices da artéria umbilical do segundo para o terceiro trimestre da gestação. As concentrações de nitrito plasmático se mantiveram estáveis ao longo da gestação. 


\title{
EFEITO DA REEDUCAÇÃO ALIMENTAR SOBRE O HÁBITO ALIMENTAR E OS PARÂMETROS ANTROPOMÉTRICOS EM ADOLESCENTES COM SOBREPESO E OBESIDADE COM SÍNDROME DOS OVÁRIOS POLICÍSTICOS
}

\author{
Adriana Lúcia Carolo \\ Orientadora: Profa. Dra. Rosana Maria dos Reis \\ Tese de Doutorado apresentada em 22/09/2011
}

Introdução: A Síndrome dos Ovários Policísticos (SOP) é uma disfunção endócrina comum em mulheres em idade reprodutiva, com manifestações de infertilidade, irregularidade menstrual e parâmetros clínicos ou bioquímicos de hiperandrogenismo. É frequentemente associada à dislipidemia e intolerância à glicose, levando ao aumento da incidência de morbidade e mortalidade por Doença Cardiovascular e Diabetes Mellitus tipo II. Obesidade é comum entre mulheres com SOP e é influenciada por vários aspectos como fatores genéticos, atividade física e dieta. Estima-se que 30 a $70 \%$ das mulheres com SOP sejam obesas. O tratamento da SOP dependerá do grau das alterações metabólicas causadas por este distúrbio. Independente da alteração metabólica ou clínica apresentada, a perda de peso deve ser considerada a primeira alternativa de terapia em mulheres com sobrepeso e obesidade com SOP.

Objetivo: Avaliar os efeitos da reeducação alimentar sobre o hábito alimentar e os parâmetros antropométricos em adolescentes com sobrepeso e obesidade com SOP.

Metodologia: Este é um estudo prospectivo, longitudinal, autocontrolado, no qual foram analisadas as respostas à reeducação alimentar sobre hábito alimentar, parâmetros antropométricos de peso, Índice de Massa Corporal (IMC) e circunferência de cintura. $\mathrm{O}$ acompanhamento nutricional teve a duração de seis meses.

Resultados: Foram selecionadas 31 pacientes, 18 permaneceram no estudo e nove perderam peso. $O$ hábito alimentar das adolescentes que perderam peso foi alterado após o período de reeducação alimentar. Elas passaram a consumir maior número de refeições por dia e ingerir dieta hipocalórica, normoglicídica, hiperproteica e normolipídica. A adoção desta dieta e a prática de exercício físico resultaram em redução de peso e da circunferência de cintura.

Conclusão: A reeducação alimentar promoveu mudanças no hábito alimentar das adolescentes com sobrepeso e obesidade, que garantiram alterações significativas nos parâmetros antropométricos e tendência de melhora nos perfis lipídicos e glicêmicos.

\section{Imunologia Básica e Aplicada}

\section{ESTUDO DA REGULAÇÃO DA RESPOSTA IMUNOLÓGICA EM MODELO DE CO-INFLAMAÇÃO ALERGIA E TUBERCULOSE}

\author{
Livia Weijenborg Campos \\ Orientadora: Profa. Dra. Vânia Luiza Deperon Bonato \\ Dissertação de Mestrado apresentada em 04/07/2011
}

A tuberculose e a alergia são doenças que afetam as vias aéreas e acometem parcela significativa da população mundial. Estudos epidemiológicos mostram que em áreas endêmicas para tuberculose ocorre menor prevalência de doenças alérgicas. Evidências experimentais também mostram que a infecção com Mycobacterium bovis BCG e a exposição a Mycobacterium vaccae morto pelo calor ou a antígenos de micobactérias modulam negativamente a resposta alérgica das vias aéreas. Porém, não existem estudos in vivo que mostrem como a resposta imunológica contra M. tuberculosis modula ou não a asma alérgica e se o contrário, a modulação da tuberculose em decorrência da asma também ocorre.Em estudo prévio, padronizamos protocolo de co-inflamação tuberculose e alergia, e verificamos que independentemente da ordem de desencadeamento das doenças experimentais ocorria redução da eosinofilia, da produção de IL-4 e IL-5, e da produção de muco no pulmão. Contudo, a susceptibilidade à infecção por $M$. tuberculosis dependia da ordem de desencadeamento das doenças. Quando a alergia era induzida primeiro, ocorria aumento significativo da carga bacilar nos pulmões do animais co-inflamados (modelo OVA/TB). Diferentemente, quando os animais eram expostos aos bacilos e desenvolviam alergia posteriormente, ocorria redução da carga bacilar nos pulmões dos animais co-inflamados (modelo TB/OVA) em relação aos animais apenas infectados (TB).Nesse estudo, nós investigamos se os mediadores lipídicos secretados após 
a indução da asma alérgica estavam associados com a diminuição do número de bacilos no pulmão de camundongos previamente infectados com M. tuberculosis (TB/OVA). Em adição, nós avaliamos o papel da citocina IFN- na modulação negativa da resposta alérgica em camundongos posteriormente infectados com M. tuberculosis (modelo OVA/TB).Nossos resultados mostram que mediadores lipídicos, como LTB4 participam da resposta imunológica que conduz à diminuição no número de bacilos no pulmão de animais que desenvolvem asma alérgica após a infecção com M. tuberculosis (TB/OVA). A diminuição no número de bacilos não foi dependente do aumento na produção de IFN- $\gamma$ ou de IL-17. Animais coinflamados TB/OVA apresentaram menor infiltrado granulomatoso e maior influxo de células CD8+ para o pulmão comparando-se ao grupo TB. Mesmo em fase mais tardia da infecção (80 dias), ainda encontramos menor número de bacilos nos animais co-inflamados e esse efeito não foi dependente do adjuvante alúmen, usado para indução da alergia. Em adição, a citocina IFN- $\gamma$ não estava associada com a redução na eosinofilia dos animais co-inflamados empregando-se o modelo OVA/TB, como supúnhamos. Porém, IFN- $\gamma$ estava relacionado com aumento na produção de muco e de IL-13. Além disso, houve aumento significativo na frequiência de células com características de linfócitos em apoptose no lavado broncoalveolar de animais do grupo OVA/TB comparando-se aos animais do grupo OVA. Esses resultados ilustram a diversidade de mecanismos imunológicos, seus mediadores e populações celulares, que podem participar da regulação da resposta imunológica na co-inflamação alergia e na tuberculose. Esse cenário reflete a complexidade das respostas imunológicas em processos co-inflamatórios. Decifrar mediadores, células e mecanismos induzidos em uma doença que passam a interferir em outra doença é uma estratégia para se desvendar a regulação da resposta imune. Tal estratégia permite que se abram perspectivas para o delineamento de novas terapias imunológicas que visem ao controle do crescimento de bacilos e/ou ao controle das respostas inflamatórias exacerbadas.

\title{
FOSFATIDILINOSITOL 3-QUINASE G (PI3KG) É ESSENCIAL PARA O CONTROLE DA INFECÇÃO EXPERIMENTAL PELO Trypanosoma cruzi: POSSÍVEL PAPEL NA ATIVAÇÃO DE MACRÓFAGOS
}

\author{
Maria Cláudia da Silva \\ Orientador: Prof. Dr. Thiago Mattar Cunha \\ Dissertação de Mestrado apresentada em 11/07/2011
}

A doença de Chagas, causada pelo parasito protozoário Trypanosoma cruzi (T. cruzi) constitui ainda hoje um grande problema de saúde pública que afeta cerca de 10 milhões de pessoas na América Latina, onde é endêmica. Após a fase inicial aguda da doença, geralmente assintomática, segue-se uma fase crônica que também pode ser assintomática, caracterizando a fase indeterminada, ou afetar o tecido digestivo, cardíaco ou ambos, podendo ser fatal. O balanço entre respostas pró e antiinflamatória, bem como a produção de quimiocinas e expressão de seus receptores é descrito como um fenótipo de resistência à infecção. Ao ser reconhecido por receptores de superfície celular, o parasito ativa sinais intracelulares que culminam na ativação de várias vias de sinalização intracelulares incluindo aquelas dependentes das fosfatidilinositol 3-quinases (PI3Ks). As diferentes classes de PI3Ks apresentam importante papel na resposta imune por controlar sinais cruciais para sobrevivência, proliferação, diferenciação, migração e remodelamento do citoesqueleto em diferentes tipos celulares. A isoforma PI3Kg, representante única da classe IB das PI3Ks é ativada quando receptores acoplados a proteínas G (GPCRs) são estimulados, estando assim envolvida em sinais quimiotáticos, diapedese e ativação de leucócitos, processos fundamentais na formação de uma resposta imune efetiva ao T. cruzi. No entanto, não existem trabalhos que avaliaram a participação da PI3Kg na fisiopatologia da doença de Chagas. Sendo assim, o objetivo desse trabalho foi avaliar o papel da PI3Kg durante a infecção experimental pelo T. cruzi. Nossos resultados mostram que camundongos infectados com T. cruzi apresentaram maior expressão e ativação da PI3Kg no tecido cardíaco, e camundongos deficientes desta enzima sucumbiram à infecção significativamente mais cedo, apesar de apresentarem quantidade de parasitos circulantes semelhantes aos camundongos controle (WT). Observamos que o fígado dos animais PI $3 \mathrm{Kg}^{-/-}$apresentava, na fase crônica da infecção, menor inflamação e lesão, mas no coração, esses mesmos parâmetros estavam aumentados. Surpreendentemente, apesar da maior inflamação no tecido cardíaco dos animais deficientes da PI3Kg, havia nesse órgão maior parasitismo quando comparados ao do animal WT. Experimentos in vitro mostram que macrófagos diferenciados a partir de células da medula óssea de camundongos PI3 $\mathrm{Kg}^{-1-}$, quando estimulados com diferentes concentrações de IFN-g falharam em produzir óxido nítrico (NO) e matar o parasito intracelular. Em conjunto, estes resultados sugerem que provavelmente a PI3Kg contribua para as funções efetoras dos macrófagos em resposta ao parasito, característica necessária para o controle da infecção por T. cruzi in vivo. 


\title{
SELEÇÃO E PRODUÇÃO DE FRAGMENTOS DE ANTICORPOS MONOCLONAIS HUMANOS (SCFV) PELA TECNOLOGIA DE Phage Display CAPAZES DE INIBIR A PROLIFERAÇÃO DE CÉLULAS T in vitro
}

\author{
Thaís Barboza Bertolini \\ Orientador: Prof. Dr. José Elpidio Barboza \\ Dissertação de Mestrado apresentada em 29/07/2011
}

A resposta imune é a principal responsável pela rejeição de transplantes, sendo considerada um grande obstáculo para o desenvolvimento terapêutico desta área. Apesar das inúmeras estratégias imunossupressoras, tais como drogas e anticorpos, que auxiliam na terapia pós-transplante, diversos efeitos colaterais incluindo imunossupressão, aumento da suscetibilidade a doenças, hipertensão arterial, náuseas e diarréia, ainda são recorrentes. Além disso, os anticorpos utilizados atualmente são heterólogos, quiméricos ou humanizados, sendo constituídos de moléculas completas de anticorpos, por isso podem ocasionar complicações indesejáveis. Essas moléculas, por serem reconhecidas como estranhas, podem ativar o sistema complemento, células do sistema imune, induzir citotoxicidade celular mediada por anticorpos e hipersensibilidades como anafilaxia e Doença do Soro. Assim, a produção de fragmentos de anticorpos humanos pela tecnologia de Phage Display apresenta-se como uma alternativa, pois os fragmentos de anticorpos produzidos são humanos, o que diminui a possibilidade de estimularem a produção de anticorpos anti-Ig e induzir reações de hipersensibilidade. Também, por se tratarem de moléculas pequenas que não possuem a região Fc da molécula de anticorpo, não são capazes de desencadear mecanismos efetores do sistema imune, como ativação do complemento e de células mononucleares.

No presente estudo foi realizada a produção de fragmentos de anticorpos monoclonais humanos (scFv) capazes de inibir a proliferação de células T, utilizando a biblioteca Griffin 1. Realizou-se um total de três turnos de seleção, sendo que os fagos-anticorpos de cada turno foram analisados por ELISA para a escolha do turno com maior título de fagosanticorpos reconhecedores de antígenos da superfície de células T. Os três turnos apresentaram positividade a antígenos da superfície de células T, mas apenas dois turnos foram utilizados para a produção de fagos-anticorpos monoclonais. Os

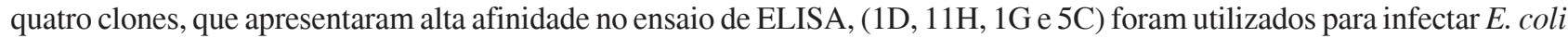
HB2151, a qual produz fragmentos de anticorpos humanos solúveis. Testes visando à inibição da proliferação de células $\mathrm{T}$ periféricas foram realizados utilizando fragmentos de anticorpos monoclonais purificados e os quatro fragmentos demonstram-se hábeis em inibir significativamente a proliferação de linfócitos. Verificou-se, também, que os quatro fragmentos de anticorpos foram capazes de promover citotoxicidade celular em ensaio de viabilidade. Entre os quatro fragmentos de anticorpos, o 1D foi utilizado em ensaio de detecção de morte celular e mostrou-se capaz de induzir apoptose nas células. Sugerindo, assim, um possível mecanismo pelo qual esses fragmentos inibem a proliferação linfocitária.

\section{Neurologia}

\section{INFLUÊNCIA DA NEUROTRANSMISSÃO NORADRENÉRGICA NO NÚCLEO DORSAL DA RAFE NA ANALGESIA INDUZIDA POR REAÇÕES DE FUGA ORIENTADA EVOCADA PELO BLOQUEIO DE RECEPTORES GABA-A NO HIPOTÁLAMO DORSOMEDIAL, NA ÁREA HIPOTALÂMICA LATERAL E NO NÚCLEO HIPOTALÂMICO PRÉ-MAMILAR DORSAL}

\author{
Carlos Jose Salgado Rohner \\ Orientador: Prof. Dr. Norberto Cysne Coimbra \\ Dissertação de Mestrado apresentada em 08/07/2011
}

O hipotálamo e estruturas do teto mesencefálico têm papel importante na organização dos comportamentos defensivos induzidos pelo medo, assim como em processos antinociceptivos. Além disso, recentes estudos mostraram que comportamentos de medo inato e de pânico induzidos pela administração de bicuculina no hipotálamo medial causam elevação dos limiares nociceptivos. Além do mais, trabalhos que utilizaram neurotraçadores retrógados, têm identificado vias recíprocas entre o núcleo dorsal de rafe (NDR) e o locus coeruleus (LC). Sendo assim, o objetivo do presente trabalho consistiu em estabelecer as conexões entre os núcleos do hipotálamo dorso-medial (HDM), do pré-mamilar (NPM) e do hipotálamo lateral (HL) com o NDR, e este, com o núcleo noradrenérgico LC, através de um estudo neuroanatômico com a 
microinjeção do neurotraçador anterógrado e retrógrado, o BDA conjugado com Texas red a $10 \%$ nas redes neurais do NDR. Também foi investigado o envolvimento da neurotransmissão noradrenérgica de um importante núcleo do sistema endógeno de inibição de dor, o NDR, na elaboração de processos antinociceptivos induzidos pela desinibição dos receptores GABAA em diferentes núcleos do hipotálamo. Para isso, foram implantadas, por meio de cirurgia estereotáxica, cânula-guia direcionada para o HDM, HL ou para o NPM, e outra cânula-guia no NDR. Após 5 dias da cirurgia, foi realizado o pré-tratamento do NDR com salina fisiológica $(\mathrm{NaCl} 0,9 \% ; 0.2 \mu \mathrm{l})$ ou WB4101 $(5 \mu \mathrm{g} / 0.2 \mu \mathrm{l})$, um antagonista de receptores $\alpha 1$-noradrenérgicos, seguido, após 10 minutos, da microinjeção no HDM ou no HL ou no NPM de salina fisiológica $(\mathrm{NaCl}$ $9 \% ; 0.2 \mu \mathrm{l}$ ) ou bicuculina (40ng/0.2 $\mu \mathrm{l}$ ), avaliando-se assim, os comportamentos induzidos pelo medo, pelos quais foram analisados quantitativamente por 10 minutos no campo aberto, sendo eles: frequencia e duração da avaliação de risco, imobilidade defensiva, fuga, saltos e levantamentos. Imediatamente após os comportamentos defensivos, os limiares nociceptivos dos animais foram avaliados até 60 minutos através do teste de latência de retirada de cauda. As microinjeções de WB4101 no NDR seguido por bicuculina no HDM, ou no HL ou no NPM causaram diminuição da frequencia e duração da avaliação de risco, imobilidade defensiva, fuga, saltos e levantamentos evocados pela desinibição dos receptores GABAA, através da microinjeção de bicuculina nos núcleos hipotalâmicos estudados no presente trabalho. Além disso, houve diminuição estatisticamente significativa na antinocicepção que segue os comportamentos de fuga elaborada, de 0 a 30 minutos após o fim dos comportamentos defensivos. Considerando que o HDM, o HL e o NPM são núcleos importantes do substrato neural responsável pela elaboração de comportamentos aversivos e de pânico, a evidência mostrada neste trabalho sugere que as conexões, possivelmente noradrenérgicas, entre o NDR e o LC modulam comportamentos defensivos elaborados pelo hipotálamo, pois a microinjeção do antagonista $\alpha 1$-noradrenérgica, o WB4101, diminuiu os comportamentos defensivos induzidos pela fuga elaborada. Adicionalmente, o presente estudo mostrou que parte da antinocicepção induzida pela fuga elaborada é mediada por receptores noradrenérgicos do tipo $\alpha 1$ localizados no NDR, pois a microinjeção de WB4101 intra NDR, causou diminuição da analgesia induzida pelos comportamentos defensivos através da desinibição GABAérgica nos núcleos hipotalâmicos.

\title{
ANALISE MUTACIONAL DOS GENES: LITAF, EGR2 E NEFL EM UMA POPULAÇÃO BRASILEIRA COM A DOENÇA DE CHARCOT-MARIE-TOOTH TIPO 1
}

\author{
Keity Cristina Bueno \\ Orientador: Prof. Dr. Wilson Marques Junior \\ Tese de Doutorado apresentada em 21/07/2011
}

A doença de Charcot- Marie-Tooth tipo 1 (CMT1), a mais comum neuropatia hereditária em humanos é caracterizada por uma heterogeneidade clínica e genética. A causa mais comum em CMT1 é a duplicação do cromossomo 17p11.2, no gene PMP22, cujo efeito da dosagem é a causa da doença. Em adição à duplicação 17p, mutações de ponto e pequenas deleções e inserções em alguns genes, como PMP22, MPZ, GJB1, LITAF, EGR2 e NEFL estão relacionados à doença. No presente estudo nós realizamos uma análise mutacional nos genes LITAF, EGR2 e NEFL em 66 pacientes brasileiros com CMT1 sem a duplicação 17p11.2 e sem mutações nos genes PMP22, MPZ e GJB1. Entre os 66 pacientes estudados nós encontramos dois pacientes com a mutação Gli112Ser no gene LITAF, um paciente com a mutação Arg381His no gene EGR2 e nenhuma mutação foi encontrada no gene NEFL. Nós também detectamos 4 diferentes polimorfismos, 2 no gene LITAF, 1 no gene EGR2 e 1 no gene NEFL em 20 pacientes. Considerando nosso estudo populacional, a prevalência de mutações nos genes LITAF e EGR2 foi de 3,0\% e 1,5\%, respectivamente. Todas as mutações encontradas foram previamente descritas em outros estudos, sugerindo tratar-se de regiões propensas a mutações. Destaca-se o fato de termos encontrado mutações nos genes LITAF e EGR2 e polimorfismos nos 3 genes analisados em uma população tão pequena, visto que elas são raras em outras populações analisadas.

\section{SÍNDROME DAS PERNAS INQUIETAS: PREVALÊNCIA, GRAVIDADE, CARACTERÍSTICAS, IMPACTO NO SONO E NA QUALIDADE DE VIDA EM CÁSSIA DOS COQUEIROS - SÃO PAULO - BRASIL}

\author{
Alan Luiz Eckelli \\ Orientador Regina Maria França Fernandes \\ Tese de Doutorado apresentada em 22/07/2011
}

Introdução: A síndrome das pernas inquietas (SPI) é uma doença neurológica caracterizada por vontade uma imperiosa para movimentar as pernas, associada a queixas sensitivas que ocorrem no período noturno, durante o repouso e 
melhoram com o movimento. Neste trabalho, estimamos a prevalência da SPI, e avaliamos sua gravidade, características, impacto no sono e na qualidade de vida, na população urbana e adulta da cidade de Cássia dos Coqueiros, São Paulo, Brasil.

Métodos: Foi realizado um estudo transversal entre julho de 2007 e agosto de 2008. As entrevistas foram conduzidas por um médico neurologista, especialista em Medicina do Sono, utilizando o questionário SF-36, para avaliar a qualidade de vida, o questionário de Pittsburgh, para a qualidade do sono, a escala de sonolência de Epworth e a escala internacional de graduação da SPI.

Resultados: Foram entrevistados 1.155 indivíduos, com uma taxa de cobertura de 94,06\%. A prevalência da SPI durante a vida foi de $6,4 \%$; as prevalências durante o último ano, o último mês, e a última semana foram $5,71 \%, 5,36 \%$ e $4,15 \%$, respectivamente.

Observou-se que 76,4\% dos indivíduos com SPI possuíam sintomas de intensidade moderada a grave. A presença de história familiar positiva para SPI ocorreu em 50\% dos casos. Houve uma maior proporção de indivíduos com doenças respiratórias e de mulheres com relato de aumento do fluxo menstrual entre os indivíduos com SPI (p<0,05). Na análise de regressão logística, as mulheres apresentaram um maior risco para SPI (OR=2,53; IC 95\%=1,50 - 4,27), assim como os indivíduos com renda mensal superior a $\$ 1.575$ USD, quando comparados aos indivíduos com renda inferior $(\mathrm{OR}=2,60$; IC $95 \%=1,26$ - 5,37). Os pacientes com SPI apresentaram uma redução significativa da qualidade de vida, nos domínios do SF36 relacionados à capacidade funcional $(p=0,03)$, estado geral da saúde $(p=0,03)$, dor $(p=0,03)$, vitalidade $(p=0,03)$ e aspectos sociais $(\mathrm{p}=0,02)$, quando comparados aos indivíduos controle. A qualidade do sono nos indivíduos com SPI foi significativamente pior nos domínios do questionário de Pittsburgh relacionados à qualidade global do sono $(\mathrm{p}=0,001)$, latência do sono $(\mathrm{p}<0,001)$, eficiência do sono $(\mathrm{p}<0,001)$, uso de medicações hipnóticas $(\mathrm{p}=0,001)$ e disfunção diurna $(\mathrm{p}=0,001)$.

Conclusão: A SPI, estudada numa comunidade urbana do Brasil, apresenta uma prevalência durante a vida de 6,4\%, com maior prevalência entre as mulheres e nos indivíduos com renda familiar mensal maior que \$1.575 USD. A SPI esteve associada à pior qualidade de vida e do sono.

\section{ULTRAESTRUTURA DO NERVO LARÍNGEO RECORRENTE NO DIABETE EXPERIMENTAL CRÔNICO: AVALIAÇÃO MORFOMÉTRICA}

\section{Maria Carolina Dal Bem de Barros Oliveti}

Orientadora: Profa. Dra. Valeria Paula Sassoli Fazan

Tese de Doutorado apresentada em 01/08/2011

O nervo laríngeo recorrente (NLR) é responsável pela inervação da maioria dos músculos intrínsecos da laringe. Apesar da existência de algumas descrições de paralisia das cordas vocais de etiologia desconhecida, em pacientes diabéticos, não existem descrições na literatura de avaliação morfométrica do NLR nesses pacientes, nem em modelos experimentais de diabete. Diabete induzido experimentalmente pela injeção de estreptozotocina (STZ) é um modelo bem estabelecido de diabete tipo 1 e tem sido amplamente utilizado na investigação de neuropatia em animais. Assim, o objetivo do presente estudo foi investigar os parâmetros morfológicos e morfométricos do NLR no diabete experimental crônico, induzido pela STZ. Ratos Wistar machos $(\mathrm{N}=5)$ receberam uma injeção única de STZ endovenosa 12 semanas antes dos experimentos. Ratos controle $(\mathrm{N}=5)$ receberam veículo. No dia do experimento, animais foram perfundidos com solução fixadora e os NLR direito e esquerdo foram retirados e preparados para estudos de microscopia de luz e eletrônica de transmissão. A morfometria foi realizada com o auxílio de um programa computacional. A análise estatística foi realizada de forma a comparar dados obtidos entre segmentos do mesmo lado, entre níveis iguais e lados diferentes e entre grupos. Diferenças foram consideradas significativas quando $\mathrm{p}<0,05$. Nossos resultados mostraram que os fascículos dos NLR são significativamente maiores nos segmentos proximais, em ambos os lados e em todos os grupos estudados, bem como o número de fibras mielínicas finas. A comparação entre os grupos mostrou que o número de fibras mielínicas foi menor nos segmentos proximais dos animais diabéticos, o que sugere a presença de uma neuropatia de fibras finas. Os parâmetros morfométricos médios das fibras mielínicas se mostraram menores nos animais diabéticos, comparados aos controles, sem, entretanto, alcançar níveis significativos. Esse resultado sugere a presença de uma neuropatia axonal concomitante, o que dificulta o diagnóstico de uma neuropatia de fibras finas. A análise das fibras amielínicas mostrou uma tendência a diminuição no número, no gradiente proximal para distal, em ambos os grupos, sem atingir níveis significativos. Não observamos diferenças nos parâmetros morfométricos das fibras amielínicas entre os grupos experimentais. Nossos resultados mostram alteração das fibras mielínicas finas do NLR nesse modelo de diabete experimental. Esses resultados podem colaborar na elucidação das patologias dos músculos laríngeos no diabete. 


\title{
PADROES DE EXPRESSÃO DE PROTEINAS ESTRUTURAIS E PLASTICIDADE NA EPILEPSIA DO LOBO TEMPORAL
}

\author{
Mariana Raquel Monteiro \\ Orientador: Prof. Dr. João Pereira Leite \\ Dissertação de Mestrado apresentada em 30/08/2011
}

Introdução: A epilepsia do lobo temporal mesial (ELTM) é a forma mais comum de epilepsia na população adulta, tendo a esclerose hipocampal como principal substrato neuropatológico. Uma elevada proporção dos pacientes com ELTM apresentam história familiar positiva para a epilepsia, sugerindo a participação de fatores genéticos nesta síndrome. O citoesqueleto neuronal é essencial para os processos fisiológicos das células nervosas e crises epilépticas parecem afetar esta estrutura. O citoesqueleto neuronal possui importantes componentes regulatórios, dentre eles as proteínas associadas aos microtúbulos do tipo 2 (MAP2) e tau.

Objetivos: Avaliar a densidade neuronal (células imunomarcadas com NeuN), neobrotamento das fibras musgosas (por histoquímica de neo-Timm) e a expressão imunohistoquímica das proteínas MAP2 e tau no hipocampo de casos cirúrgicos de ELTM (subtipos familiar e esporádico) e controles. As mesmas análises foram conduzidas no modelo animal de lítio-pilocarpina.

Métodos: Casos ELTM ( $\mathrm{n}=38)$ foram divididos em ELTM familiar $(\mathrm{n}=20)$ e ELTM esporádica $(\mathrm{n}=18)$. Hipocampos controles $(\mathrm{n}=10)$ foram provenientes de necrópsias de sujeitos sem histórico de problemas neurológicos. No modelo animal de lítio-pilocarpina, animais submetidos ao status epilepticus (SE) foram sacrificados nos seguintes tempos pósSE: 1, 7, 15 e 60 dias e classificados como grupos SE1, SE7, SE15 e SE60. Animais controle foram injetados com salina. Resultados: O grupo ELTM apresentou menor densidade neuronal que o controle nas regiões da camada granular, hilo, CA4, CA3, CA1 e prosubículo. O grupo ELTM mostrou maior valor de cinza da histoquímica de neo-Timm na camada granular, molecular interna e molecular externa e maior espessura do neobrotamento axonal na camada molecular interna em relação ao grupo controle. O grupo ELTM esporádica teve maior valor de cinza da histoquímica de neo-Timm e tendência à maior espessura do neobrotamento que o grupo ELTM familiar na camada molecular interna. O grupo ELTM apresentou menor expressão de MAP2 que o grupo controle no hilo, CA4, CA3, CA1 e prosubículo e maior expressão que o controle na camada granular, CA2 e parasubículo. O grupo ELTM esporádica teve maior expressão de MAP2 que o grupo ELTM familiar em CA1 e córtex entorrinal. O grupo ELTM apresentou maior expressão de tau que o grupo controle nas regiões da camada granular, hilo, CA3, CA2 e córtex entorrinal. O grupo ELTM esporádica demonstrou menor imunorreatividade para tau que o grupo ELTM familiar no córtex entorrinal. No modelo de lítio-pilocarpina, os grupos submetidos ao SE apresentaram menor densidade neuronal e maior neobrotamento que o grupo salina. Quanto à expressão de MAP2, os grupos SE60 e SE15 apresentaram maiores valores de expressão que os demais grupos em todas as regiões analisadas. A expressão de tau em CA3 não foi diferente entre os grupos animais analisados. Conclusão: Nossos resultados demonstraram perda neuronal, reorganização sináptica das fibras musgosas e alterações na expressão de proteínas MAP2 e tau no hipocampo de pacientes com ELTM. Dentre os casos ELTM, encontramos diferenças no neobrotamento de fibras musgosas e na expressão de MAP2 e tau entre os grupos ELTM familiar e esporádica, indicando que estes grupos se apresentam de forma distinta em relação à epilepsia. Encontramos resultados semelhantes em relação à densidade neuronal e o neobrotamento de fibras musgosas entre pacientes com ELTM e no modelo experimental. Porém, em relação à expressão das proteínas MAP2 e tau, encontramos algumas diferenças entre humanos e animais com ELTM. Nossos resultados sugerem que apesar do modelo de epilepsia induzida por lítio-pilocarpina ser relevante para o estudo da ELTM humana e mimetizar importantes aspectos neuropatológicos, a correspondência quanto à expressão de algumas proteínas estruturais não é completa. Estudos adicionais de expressão de proteínas do citoesqueleto em outros modelos animais de ELTM serão de grande importância para o melhor entendimento do processo epileptogênco.

\section{EFEITO DE UM PROGRAMA DE EXERCÍCIOS NA BRADICINESIA DE MEMBROS SUPERIORES EM PACIENTES COM DOENÇA DE PARKINSON}

\author{
Monica de Biagi Curtarelli \\ Orientador: Prof. Dr. Vitor Tumas \\ Dissertação de Mestrado apresentada em 26/09/2011
}

Introdução: A DP é definida como uma enfermidade crônica de caráter progressivo e degenerativo do sistema nervoso central que afeta os gânglios da base. O quadro clínico mais comum é a tríade clássica caracterizada por tremor de 
repouso, bradicinesia e rigidez muscular. A bradicinesia é manifestada por uma lentidão do movimento, e pode ser definida como um distúrbio na relação amplitude-velocidade e indica que os movimentos envolvendo grandes amplitudes são realizados em velocidades anormalmente baixas. O objetivo da fisioterapia nesses pacientes é melhorar a qualidade de vida mantendo ou aumentando a independência do paciente, prevenindo a inatividade e quedas, melhorando a funcionalidade e diminuindo limitações. Depois de feita uma revisão sistemática foi possível verificar que não existem muitos estudos mostrando o efeito de um programa de exercícios para a bradicinesia de membros superiores, porém a literatura relata que o treino com exercícios resistidos pode ser a melhor maneira de se ganhar velocidade nesses pacientes.

Objetivo: Através disso, o objetivo do presente estudo foi avaliar os efeitos da fisioterapia na bradicinesia de membros superiores em pacientes com DP.

Métodos:Os participantes foram selecionados através do ambulatório de Distúrbios de Movimento do HCFMRPUSP e divididos em dois grupos. O grupo controle foi orientado a realizar exercícios domiciliares e o grupo experimental realizou um programa de exercícios de resistência muscular para membros superiores. Foram avaliados antes e depois do treino, com as seguintes escalas e instrumentos de avaliação: UPDRS, Hoehn and Yahr, Schwab \& England, testes cronometrados, Peg Board test, The Modified Bradykinesia rating scale (MBRS)(A-C), RM, Beck, PDQ-39, GABS e CGI. Todos os pacientes, voluntários ou responsáveis legais assinaram um termo de consentimento livre e esclarecido após informação detalhada sobre o trabalho e sua participação.

Resultados: Foram avaliados 43 pacientes, porém concluíram o estudo 12 do grupo intervenção e 20 do grupo controle. Em relação ao Peg Board test no teste 5 para o grupo intervenção e no teste 4 para o grupo controle, porém não houve diferença entre os grupos. Para os testes cronometrados houve uma diferença estatística para o grupo intervenção na tarefa de polegar indicador esquerdo e alcance de dois alvos com o membro superior direito, enquanto que para o outro grupo a diferença foi no teste de alcance de dois alvos com o membro superior esquerdo. As demais avaliações não demostraram diferenças estatísticas importantes entre os dois grupos, somente a escala CGI que mostrou um p de 0,007 entre os dois grupos.

Conclusão: Podemos concluir que novos estudos terão que ser realizados na mesma área, pois como houve diferença estatística na impressão clinica dos próprios pacientes, talvez nossos instrumentos não tenham sido sensíveis o suficiente.

\title{
Oftalmologia, Otorrinolaringologia e Cirurgia de Cabeça e Pescoço
}

\author{
EFEITO DO USO DE IMPLANTES DE LIBERAÇÃO LENTA DE BEVACIZUMABE NA \\ TRABECULECTOMIA EXPERIMENTAL DE COELHOS
}

\author{
Vanessa Raquel Coimbra Ribeiro \\ Orientador: Prof. Dr. Jayter Silva de Paula \\ Dissertação de Mestrado apresentada em 20/07/2011
}

Objetivo: O fator de crescimento do endotélio vascular (VEGF) está potencialmente envolvido em processos cicatriciais relacionados aos tecidos oculares. O presente estudo tem como objetivo avaliar o efeito do implante de poliuretano com Bevacizumabe (IPUB) como um novo sistema de liberação da droga em um modelo experimental de cirurgia fistulizante para o glaucoma em coelhos.

Métodos: Os implantes foram preparados por meio do método convencional de dispersão aquosa de poliuretano. Eles foram moldados nas dimensões de 3X3X1 mm e uma parte deles recebeu 1,5 mg de Bevacizumabe. Os animais foram divididos em grupos de cinco (Grupo 1, n=10) e quinze dias (Grupo 2, n=10) de seguimento e subdivididos em subgrupos dos que receberam implantes com (1B e 2B) ou sem (1A e 2A) IPUB. Durante o procedimento cirúrgico, os implantes foram fixados no espaço subconjuntival desses olhos. Os efeitos dos IPUB foram estudados por meio da medida da pressão intraocular (PIO), do aspecto da ampola filtrante (pelo Moorfields bleb grading system), da deposição de colágeno, da contagem de neutrófilos e da análise immunohistoquímica da expressão do VEGF-A nos fibroblastos do sítio cirúrgico.

Resultados: A avaliação in vivo não demonstrou nenhum efeito adverso relacionado à presença dos implantes cirúrgicos. A avaliação clínica não mostrou diferença significativa na redução da PIO e dos aspectos da ampola filtrante, a não ser, o grupo 2B que apresentou maior altura e vascularização da ampola do que o grupo 2A (p=0,048, em ambos). A 
análise da densidade de colágeno e da contagem neutrofílica não demonstrou diferenças estatisticamente significativas entre os grupos. A proporção de fibroblastos expressando VEGF-A foi significativamente menor apenas no grupo 1B ( $\mathrm{p}=0,0051$; teste $\mathrm{U}$ de Mann-Whitney).

Conclusão: Este estudo demonstrou que o IPUB foi bem tolerado em olhos de coelhos e promoveu redução da expressão do VEGF-A em fibroblastos da área cirúrgica, provavelmente devido à liberação de Bevacizumabe por um curto período de tempo. Novos estudos farmacocinéticos com IPUB modificados serão necessários para melhorar esses resultados, otimizando a biodisponibilidade e modulação do processo cicatricial, com mínimos efeitos adversos.

\title{
AVALIAÇÃO CEFALOMÉTRICA DO PADRÃO FACIAL E POSICIONAMENTO DO OSSO HIOIDE EM CRIANÇAS COM SÍNDROME DA APNEIA OBSTRUTIVA DO SONO
}

\author{
Bruno Boaventura Vieira \\ Orientadora: Profa. Dra. Fabiana Cardoso Pereira Valera \\ Dissertação de Mestrado apresentada em 15/08/2011
}

Objetivo: Avaliar a morfologia facial e o posicionamento do osso hioide em crianças com Síndrome da Apneia Obstrutiva do Sono (SAOS) por meio de radiografias cefalométricas laterais.

Casuística e Métodos: O estudo consiste em avaliação e comparação de medidas cefalométricas entre grupos de crianças respiradoras nasais e com SAOS, sendo cada grupo composto por 20 crianças, com idade entre 07 a 10 anos, em dentição mista e sem quaisquer tratamentos ortodônticos ou fonoaudiológicos. Todas as crianças foram submetidas à avaliação otorrinolaringológica e polissonográfica em laboratório de sono, para confirmação diagnóstica.

Resultados: Diferenças estatisticamente significantes foram encontradas, com aumento linear do terço inferior da face e também no posicionamento específico do osso hioide, que se mostrou mais anterior e inferior nas crianças portadoras de SAOS. Não foram encontradas diferenças nas medidas referentes ao terço superior da face.

Conclusão: Os resultados sugerem que a SAOS é um fator causal importante de alterações no padrão facial de crianças entre 07 e 10 anos de idade, caracterizado pelo aumento do terço inferior da face e anteriorização e inferiorização do osso hioide, avaliados por meio de radiografias cefalométricas laterais.

\section{DIPLOPIA APÓS DESCOMPRESSÃO ORBITÁRIA ÍNFERO-MEDIAL: O EFEITO DA DIMENSÃO PRÉ-OPERATÓRIA DA MUSCULATURA OCULAR EXTERNA}

\author{
Felipe Eing \\ Orientador: Prof. Dr. Antonio Augusto Velasco e Cruz \\ Tese de Doutorado apresentada em 19/08/2011
}

O presente trabalho teve como objetivo determinar a frequência de diplopia após a descompressão ínfero-medial na orbitopatia de Graves (OG), bem como investigar a influência das dimensões da musculatura ocular externa no desenvolvimento de desequilíbrio oculomotor pós-operatório. A amostra estudada foi constituída por 114 pacientes que não apresentavam diplopia antes da cirurgia. Um único corte tomográfico coronal $(9 \mathrm{~mm}$ posterior ao fechamento do rebordo orbitário lateral) foi utilizado para estabelecer o índice muscular (IM) dos músculos retos medial (RM), inferior (RI) e lateral (RL) e do complexo superior (CS). A área muscular de cada músculo foi determinada com auxílio do programa Image J 1.42. Um grupo controle de 56 pacientes submetidos à tomografia computadorizada de órbitas também foi mensurado. Dos 114 pacientes descomprimidos, 17 apresentaram diplopia após a cirurgia. As dimensões musculares puderam ser mensuradas em 103 pacientes (16 pacientes que induziram diplopia e 87 que permaneceram sem diplopia no pós-operatório). O tamanho dos músculos retos medial e inferior foi significativamente associado ao desenvolvimento de diplopia. Os pacientes com IM do RM acima do valor máximo do grupo controle apresentaram risco de indução de diplopia 13 vezes maior do que aqueles cujas dimensões eram comparáveis às do grupo controle. Em relação ao RI, o risco foi de cinco vezes. Nenhuma associação foi encontrada entre o desenvolvimento de diplopia e o tamanho do RL e do CS. O exame do equilíbrio oculomotor mostrou, de maneira global, nítida preponderância de esotropias associadas a pequenos desvios verticais, tanto nos pacientes com diplopia persistente quanto naqueles sem diplopia pós-operatória. Os resultados do presente trabalho mostraram que as dimensões dos músculos RM e RI são fatores preditivos importantes na gênese da diplopia pós-operatória. 


\title{
Ortopedia, Traumatologia e Reabillitação
}

\section{ANÁLISE MORFOMÉTRICA DO PROCESSO ODONTÓIDE POR MEIO DA RECONSTRUÇÃO MULTIPLANAR COM TOMOGRAFIA COMPUTADORIZADA MULTIDETECTORES}

\author{
Murilo Tavares Daher \\ Orientador: Prof. Dr. Helton Luiz Aparecido Defino \\ Dissertação de Mestrado apresentada em 11/07/2011
}

A fixação anterior por meio de parafuso de compressão é o tratamento de escolha para a maioria das fraturas que acometem o colo do processo odontóide. Para tal, no entanto, é necessário conhecer de maneira detalhada e anatomia do processo odontóide e realizar um bom planejamento cirúrgico. O objetivo do estudo foi avaliar, por meio de tomografia computadorizada, os parâmetros morfométricos do processo odontóide relacionados com a sua fixação interna, sua morfologia e a porcentagem de pacientes que comportam dois implantes em sua fixação. Foram avaliados 95 exames de tomografia computadorizada da coluna cervical que permitissem o estudo do áxis. Destes, 44 (46£) pertenciam a indivíduos do sexo masculino. A média de idade foi 40,47 anos. Foram excluídos os casos com diagnóstico de tumores, infecções, sequelas de fratura, artrose muito avançada ou mau-formação congênita. Nenhum dos exames tinha como indicação problemas com coluna cervical alta. Foram avaliados parâmetros relacionados a altura do odontóide e do axis, dos diâmetros do odontóide medidos ao nível de seu corpo e de seu colo, tanto nos planos sagital quanto coronal, e parâmetros relacionados à instrumentação do odontóide por via anterior. Os valores foram comparados entre os pacientes do sexo masculino e feminino. Também foi avaliada a forma do processo odontóide, classificado de acordo com sua morfologia. Finalmente, foi avaliada a porcentagem de pacientes que comporta a colocação de um segundo parafuso em sua fixação interna por via anterior. Os parâmetros lineares apresentaram resultados significativamente maiores na população masculina, comparados aos resultados encontrados na população feminina, na maioria dos casos. A forma do odontóide é predominantemente pediculada no plano coronal, e lordótipo no plano sagital. Uma porcentagem importante de paciente não comporta a colocação de um segundo implante em sua osteossintese, por via anterior, e essa proporção é ainda maior nas mulheres.

\section{EFEITOS DA APLICAÇÃO DE DIFERENTES PROTOCOLOS DE REABILITAÇÃO EM MÚSCULOS ESQUELÉTICOS DE RATAS SUBMETIDAS PREVIAMENTE À IMOBILIZAÇÃO DO MEMBRO POSTERIOR DIREITO}

\author{
Anabelle Silva Cornachione \\ Orientadora: Profa. Dra. Ana Cláudia Mattiello-Sverzut \\ Tese de Doutorado apresentada em 12/08/2011
}

É sabido que o exercício do tipo excêntrico e o alongamento são protocolos frequentemente aplicados na reabilitação do sistema músculo esquelético. O objetivo do presente estudo foi analisar as respostas teciduais dos músculos sóleo e plantar, de ratas adultas imobilizadas por 10 dias e depois submetidas a programas de reabilitação em dois períodos diferentes (10 e 21 dias). Quarenta e duas ratas Wistar adultas foram divididas em 9 grupos: Três grupos controles; Imobilizado 10 dias; Imobilizado e Treinado Excentricamente durante 10 e 21 dias; Imobilizado e Alongado durante 10 e 21 dias; e Anestesiado. Após os procedimentos os músculos sóleo e plantar foram removidos e dois fragmentos foram obtidos de cada músculo. O primeiro fragmento foi congelado e processado sob diferentes métodos histológicos, histoenzimológico, bioquímico e imunohistoquímico. O outro fragmento foi incluído em historesina para realização da técnica de microscopia de alta resolução. Os resultados foram subdivididos em três experimentos. Experimento 1: efeitos do exercício excêntrico após procedimento de imobilização. Experimento 2: efeitos do alongamento mantido após procedimento de imobilização. Experimento 3: comparação dos dados obtidos com os procedimentos de reabilitação acima. De acordo com os experimentos 1 e 2 a imobilização determinou anormalidades morfológicas no músculo sóleo como fibras em alvo, centralização nuclear, redução do número de fibras do tipo I e aumento das fibras tipo IIC, redução do diâmetro menor das fibras tipos I, IIA e IIAD, redução do número de capilares por fibra, redução da expressão da MHCI e aumento da expressão dos colágenos tipos I e III. O plantar mostrou redução do diâmetro das fibras tipos I, IIC, IIA e IID e aumento da expressão dos colágenos tipos I e III. Após 10 dias de exercício excêntrico (experimento 1) foi observado redução das 
fibras em alvo no sóleo mas aumento da centralização nuclear e fibras lobuladas. Este mesmo período de treinamento não foi eficaz para garantir a distribuição proporcional dos diferentes tipos de fibras, relação capilar/fibras, expressão da MHCI e expressão dos colágenos, como observado no controle. Contudo, 21 dias de reabilitação melhorou as anormalidades alcançando valores obtidos no grupo controle. No plantar 10 dias de treinamento excêntrico aumentou o diâmetro menor das fibras e reduziu a expressão dos colágenos tipos I e III. Considerando o experimento 2 foi possível observar que 21 dias de alongamento incrementaram a proporção de fibras e o diâmetro menor, no músculo sóleo. Porém, este período não foi eficaz para restabelecer os aspectos morfológicos, relação capilar/fibra e expressão de ambos os tipos de colágenos, como no grupo controle. A análise comparativa, experimento 3, mostrou que o treinamento excêntrico foi mais efetivo no restabelecimento das variáveis citoarquiteturais e quantitativas analisadas, que o alongamento mantido. Nossos dados mostraram que o período para recuperar o músculo sóleo é maior do que para o músculo plantar, principalmente considerando que as alterações observadas no primeiro são superiores as observadas no segundo.

\title{
DESENVOLVIMENTO DE UM SISTEMA MODIFICADO DE SUSPENSÃO DO RATO PELA CAUDA, COMO MODELO DE OSTEOPENIA
}

\author{
Mauricio Jose Falcai
}

Orientador: Prof. Dr. José B. Volpon

Dissertação de Mestrado apresentada em 19/08/2011

A suspensão do rato pela cauda é método usado para simular os efeitos da microgravidade e hipoatividade física sobre o sistema musculoesquelético e outros sistemas. O método convencional usa a tração cutânea para a fixação da cauda do animal ao sistema de suspensão, sendo idealmente aplicado durante até três semanas. Depois desse período surgem lesões cutâneas, situações estressantes e soltura dos animais. Estes fatos limitam observações por períodos mais longos.

O objetivo deste trabalho foi propor e avaliar um sistema de suspensão do rato pela cauda que utiliza tração esquelética com fio de Kirschner atravessado na vértebra caudal, comparando sua eficiência como modelo de osteopenia com a tração cutânea convencional, durante três e seis semanas.

Metodologia: 60 ratas foram distribuídas em seis grupos: GI - três semanas suspensão pela cauda em tração esquelética; GII - três semanas de suspensão em tração cutânea; GIII - três semanas sem suspensão; GIV - seis semanais suspensão em tração esquelética; GV - seis semanais suspensão em tração cutânea; GVI - seis semanas sem suspensão. Avaliação foi clínica com preenchimento de lista diária de achados de estresse e exame post-mortem com determinação dos níveis de corticosterona plasmática e estado da mucosa gastroesofágica. Avaliação dos efeitos da suspensão sobre osso ocorreu por meio da determinação da densidade mineral óssea, ensaio mecânico e histimorfometria, realizados tanto no fêmur, quanto no úmero.

Resultados: não houve diferença estatisticamente significante entre os grupos suspensos observados durante três semanas, para quaisquer dos parâmetros investigados. Entretanto, em seis semanas, sete animais em tração cutânea foram perdidos por lesões de pele e, na tração esquelética, apenas um. Quanto ao ganho de peso corporal e os outros parâmetros clínicos não houve diferenças entre os grupos suspensos foram comparados com os controles. Entretanto, depois estabilizaram, tanto para os animais suspensos pela tração cutânea, quanto esquelética, sem diferenças entre eles. No úmero não houve diferenças importantes entre os animais suspensos e os controles.

Conclusão: O sistema de tração esquelética foi mais eficiente para manter os animais suspensos até seis semanas, quando o número de complicações foi menor que na tração cutânea. A eficiência de ambos os métodos de suspensão em termos de enfraquecimento ósseos foi semelhante em ambos os grupos.

\section{EFEITOS DA PERIODIZAÇÃO DO TREINAMENTO SOBRE A MODULAÇÃO AUTONOMIA CARDÍACA E MARCADORES DE ESTRESSE ENDÓGENOS EM ATLETAS DE VOLEIBOL}

\section{José Henrique Mazon}

Orientador: Prof. Dr. Hugo Celso Dutra de Souza

Dissertação de Mestrado apresentada em 13/09/2011

Nós investigamos os efeitos do modelo de periodização de cargas seletivas (MPCS) sobre a modulação autonômica da variabilidade da frequência cardíaca (VFC) e marcadores de estresse endógenos, antes e após um período de competi- 
ção, em jogadores de voleibol (N+32). O protocolo experimental para a avaliação da VFC consistiu do uso da análise espectral das séries temporais compostas dos intervalos R-R derivados do eletrocardiograma obtidos na posição supina e durante o teste de inclinação (tilt test). Os níveis dos marcadores de estresse foram determinados pela quantificação da concentração plasmática de catecolaminas endógenas, cortisol e testosterona livre. Os resultados não demonstraram alterações na VFC antes e após o período de competição. Em constraste, a quantificação da concentração plasmática dos marcadores de estresse endógenos revelou reduções nos níveis de catecolaminas totais, noradrenalina e cortisol. Estas mudanças foram acompanhadas por aumentos na concentração de testosterona livre e na razão testosterona/cortisol. Em conclusão, nossos resultados demonstraram que o MPCV não alterou a modulação autonômica da VFC, mas promoveu adaptações benéficas aos atletas, incluindo mudanças positivas na concentração plasmática dos marcadores de estresse endógenos analisados. A ausência de alterações na VFC indica que houve relação direta entre modulação autonômica cardíaca e marcadores de estresse endógenos no presente estudo.

\title{
EFEITOS DA MASSOTERAPIA NA PERFUSÃO CEREBRAL AVALIADOS PELA TOMOGRAFIA POR EMISSÃO DE FÓTON ÚNICO EM PACIENTES COM DOR ONCOLÓGICA
}

\author{
Adriana da Silva Martins Ferreira \\ Orientadora: Profa. Dra. Gabirela Rocha Lauretti \\ Tese de Doutorado apresentada em 30/09/2011
}

Estudos apontam a massoterapia como uma técnica complementar eficaz no controle de sintomas do câncer avançado, podendo ser avaliada através de técnicas de neuroimagem como a Tomografia por Emissão de Fóton único para comprovar os seus efeitos no fluxo sanguíneo cerebral. Este estudo foi proposto para avaliar analgesia e efeitos das massoterapias através da avaliação clínica, concentração plasmática da noradrenalina e perfusão cerebral em pacientes com dor oncológica. Participaram do estudo, após aprovação do comitê de ética e consentimento livre e esclarecido, 16 pacientes portadores de neoplasia maligna de próstata, rim, reto e cólon com metástases ósseas disseminadas, os quais apresentavam dor classificada. O grupo Massoterapia recebeu 20 minutos de massoterapia em técnica padronizada por 10 dias consecutivos, além do atendimento fisioterapêutico respiratório e motor diários. Ambos os grupos foram submetidos à Tomografia por Emissão de Fóton Único antes e após a intervenção para a avaliação do fluxo sanguíneo cerebral. Foram avaliados também: dor, ansiedade e depressão e a concentração plasmática de noradrenalina foi considerado significativo. Os grupos foram demograficamente semelhantes em relação à religião, idade, escolaridade, tabagismo, etilismo, grau inicial de ansiedade e depressão imediatamente antes de serem integrados ao estudo e também semelhantes em relação ao consumo de morfina e fármacos adjuvantes. O grupo $\mathrm{M}$ apresentou diminuição do escore de dor, menor nível de ansiedade e depressão enquanto o consumo diário de morfina se manteve constante durante os dez dias de tratamento. Neste grupo foi encontrado hiperperfusão em apenas uma área do cérebro, que corresponde a funções a funções sensoriais como localização do toque, temperatura, vibração e dor e manteve os níveis plasmáticos de noradrenalina do início do estudo. O grupo C não apresentou diminuição do escore de dor, não apresentou melhora nos níveis de ansiedade e depressão e apresentou um crescente consumo diário de morfina. Neste grupo foi encontrado hiperperfusão em quatro áreas do cérebro que correspondem à antecipação da dor, preocupação, controle motor e resposta a estímulos. A realização da massoterapia resultou em diminuição da intensidade da dor, diminuição do nível de ansiedade e depressão, diminuição dos níveis plasmáticos de noradrenalina e hiperperfusão em apenas uma área cerebral o que mostra ser uma técnica importante para o controle de sintomas do câncer avançado.

\section{Patologia Experimental}

\section{A INFLUÊNCIA DA DIETA RICA EM GORDURA, DO EXERCÍCIO FÍSICO E DA COMPOSIÇÃO CORPORAL NA CARCINOGÊNESE COLÔNICA EM RATOS Wistar}

\section{Cleverson Rodrigues Fernandes}

Orientador: Prof. Dr. Sérgio Britto Garcia

Tese de Doutorado apresentada em 19/07/2011

Objetivo: Avaliar os efeitos do exercício físico, dieta rica em gordura e composição corporal na prevenção do câncer de cólon, através da análise de biomarcadores relacionados à carcinogênese colônica em ratos Wistar. 
Metodologia: A dieta controle $(\mathbf{C})$ foi a dieta padrão Purina ${ }^{\circledR}$ para ratos e a dieta rica em gordura $(\mathbf{G})$ foi a dieta padrão acrescida a 14,6\% de gordura animal. O carcinógeno utilizado foi a 1,2 dimetilhidrazina (d). Os protocolos de natação foram de 5 dias por semana, durante 8 semanas e tiveram como diferencial o tempo de exercício, que foi de 20 minutos (E20) ou 90 minutos (E90). Os grupos sedentários (S) não praticaram exercício. Foram utilizados noventa e seis animais divididos aleatoriamente em 12 grupos: seis grupos foram alimentados com a dieta padrão Purina ${ }^{\circledR}$ (CS, CSd, CE20, CE20d, CE90, CE90d) e seis com a dieta rica em gordura (GS, GSd, GE20, GE20d, GE90, GE90d).

Resultados: A dieta rica em gordura foi associada a maior ganho de peso. A área de gordura abdominal estava aumentada nos grupos que consumiram a dieta $\mathbf{G}$ em relação aos grupos que consumiram a dieta $\mathbf{C}$ e diminuida apenas no grupo CE90. A área de gordura visceral estava reduzida nos grupos CE20, CE20d, CE90, CE90d e não foi influenciada pelo exercício nos grupos G. Os níveis séricos de colesterol total estavam reduzidos nos grupos CE90, CE90d e elevados no grupo GS. Os níveis séricos de triglicerídeos estavam elevados nos grupos CS e GSd. Os níveis séricos de glicose estavam elevados no grupo GS. As concentrações teciduais de malondialdeído (MDA) no cólon, estavam elevadas nos grupos CSd, GS e GSd. As concentrações teciduais de glutationa reduzida (GSH) no cólon estavam reduzidas em todos os grupos que receberam a dieta rica em gordura. A proliferação celular colônica estava elevada em todos os grupos que receberam o DMH e reduzida nos grupos que praticaram 90 minutos de exercício. O exercício físico foi associado à redução da expressão da ciclooxigenase-2 (COX-2) nos grupos CE20d, CE90d, GE90 e GE90d . A expressão da caspase-3 estava aumentada nos grupos CE90, CE90d, GE90 e GE90d. Criptas aberrantes displásicas foram encontradas nos grupos que receberam DMH, sendo que e o exercício físico (20 e 90 minutos) foi associado à redução de seu número.

Conclusão: Apesar dos melhores resultados associados a modulação dos biomarcadores relacionados ao câncer de cólon avaliados neste trabalho, estarem relacionados à prática de noventa minutos de exercício físico, o treinamento de vinte minutos foi efetivo na redução do número dos focos de criptas displásicas, independentemente do tipo de dieta.

\title{
O PAPEL DA HIPÓXIA TUMORAL NOS CARCINOMAS MAMÁRIOS QUE SUPEREXPRESSAM MUC1
}

\author{
Juliana da Silva Zanetti \\ Orientador: Prof. Dr. Alfredo Ribeiro-Silva \\ Dissertação de Mestrado apresentada em 30/09/2011
}

O câncer de mama é o resultado de várias alterações genéticas capazes de promover o crescimento anormal, incluindo alterações nas vias apoptóticas, ativação de protooncogenes em ocogenes, inativação de genes supressores de tumor, dentre várias outras mudanças. Durante o desenvolvimento e progressão tumoral o suprimento local de oxigênio e nutrientes se tornam inadequado, condição conhecida como hipóxia tumoral. No câncer, a hipóxia é um importante fator que promove a metástase e estimula a angiogênese e a progressão tumoral. O fator induzido pela hipóxia (HIF-1 $\alpha$ ) e a anidrase carbônica IX (CAIX) são duas moléculas chave envolvidos neste processo. A mucina 1 (MUC1) é uma glicoproteína de membrana expressa na membrana apical das células de diversos tecidos. A MUC1 é envolvida na sinalização celular, inibição da adesão célula- célula e célula- matriz, apoptose, proliferação e transcrição de genes. O papel da hipóxia, entretanto, em carcinomas ductais invasores positivos para a MUC1 ainda necessita ser mais bem investigado. Neste estudo, utilizando tissue microarrays com 243 carcinomas ductais invasores, a expressão imuno-histoquímica de MUC1 foi correlacionada com marcadores associados à hipóxia (HIF-1 $\alpha$ e CAIX), assim como vários outros marcadores imunohistoquímicos e clínicos-patológicos de significado prognóstico em Patologia Mamária. A MUC1 foi superexpressa em $37 \%$ dos carcinomas e correlacionou-se com a expressão de receptores de estrógeno (RE) $(p=0,0001)$, receptores de progesterona $(\mathrm{RP})(\mathrm{p}=0,0001), \mathrm{HIF}-1 \alpha(\mathrm{p}=0.006)$, fator de crescimento vascular endotelial (VEGF) $(\mathrm{p}=0.024), \mathrm{p} 53(\mathrm{p}=0.025)$ e fator nuclear $8 \mathrm{\kappa B}(\mathrm{NF}-8 \mathrm{\kappa B})(\mathrm{p}=0,0001)$. Com exceção dos receptores hormonais e o p53, a MUC1 não se correlacionou com os parâmetros clínicos-patológicos clássicos em Patologia Mamária. Nossos dados sugerem que a superexpressão da MUC1 pode modular a resposta à hipóxia tumoral por atenuar a ativação do HIF-1 $1 \alpha$ e que a MUC1 pode contribuir para a transcrição de genes através da interação com os receptores hormonais (RE e RP). Também observamos que em carcinomas MUC1 positivos há distúrbios no ciclo celular, fato evidenciado pela quantidade de células positivas para a forma inativa da p53. Possivelmente este distúrbio se acentua devido à ocorrência da translocação do NF-8 kB para o núcleo promovida pela MUC1 que culmina no bloqueio da apoptose e consequentemente promoção da sobrevivência celular. 


\title{
Saúde da Criança e do Adolescente
}

\section{DEFICIÊNCIA DE VITAMINA A EM ADOLESCENTES DO SEXO MASCULINO ATENDIDOS EM UMA UNIDADE BÁSICA DE SAÚDE}

\author{
Cristiane Simões Bento de Souza \\ Orientador: Prof. Dr. Ivan Savioli Ferraz \\ Dissertação de Mestrado apresentada 20/07/2011
}

Introdução: A Deficiência de vitamina A (DVA) é uma das carências nutricionais mais prevalentes no mundo. É um problema de saúde pública com elevada morbidade e mortalidade em vários países em desenvolvimento. Acomete principalmente crianças pré-escolares, gestantes e nutrizes. Poucos trabalhos estudam a prevalência de DVA entre adolescentes.

Objetivos: verificar a prevalência de DVA em adolescentes atendidos em um ambulatório de pediatria geral no município de Ribeirão Preto (SP); estudar a influência de indicadores socioeconômicos e bioquímicos no status de vitamina A desta população.

Materiais e métodos: Desenho: estudo descritivo transversal de prevalência; Amostragem: 80 adolescentes do sexo masculino entre 10 e 19 anos. Métodos: teste +S30DR (o adolescente recebeu uma dose oral de 200.000UI de vitamina A imediatamente antes da primeira coleta de sangue. Uma segunda amostra foi obtida 30 a 45 dias após para determinação do +S30DR); dosagem da Proteína C Reativa; entrevista e avaliação antropométrica.

Resultados: 43,8\% (35/80) adolescentes apresentaram testes +S30DR positivos. As médias dos níveis de retinol

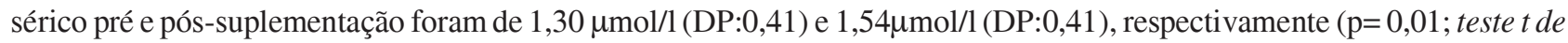
Student). Idade, renda familiar, número de pessoas no domicílio e escolaridade dos pais não se mostraram como fatores de risco para a DVA. Os níveis séricos de PCR e os episódios febris e diarréicos não alteraram os valores finais de +S30DR.

Conclusões: A elevada prevalência de DVA nesta população sugere a realização de novos estudos que possam comprovar ser pertinente a inclusão desta faixa etária em programas de prevenção e erradicação desta carência nutricional.

\section{VIA WNT/b-CATENINA EM TUMORES ADRENOCORTICAIS PEDIÁTRICOS}

\section{Letícia Ferro Leal}

Orientador: Prof. Dr. Sonir Roberto Rauber Antonini

Dissertação de Mestrado apresentada em 21/07/2010

Introdução: Em crianças das regiões Sul e Sudeste do Brasil há uma incidência elevada de tumores adrenocorticais (TAC). Anormalidades da $\beta$-catenina tem sido encontradas em TAC em adultos e sugerem a ativação da via Wnt/ $\beta$-catenina nestes tumores. No entanto, não há estudos avaliando o papel desta via em casuísticas de TAC pediátricos.

Objetivos: Avaliar o papel da via Wnt/ $\beta$ catenina e mutações do gene $C T N N B 1$ na tumorigênese adrenocortical pediátrica.

Indivíduos, Material e Métodos: Foram avaliados 62 pacientes pediátricos com TAC oriundos de dois centros de referência. Controles: córtex adrenal de indivíduos jovens com morte acidental. Avaliou-se a presença de mutação nos genes TP53 e CTNNB1. A expressão de genes da via Wnt (CTNNB1, o ligante WNT4, os inibidores SFRP1, DKK3 e AXIN1, o fator de transcrição TCF7 e os genes-alvo MYC e WISP2) foi avaliada por qPCR, utilizando-se o método de $2{ }^{-{ }^{\Delta}} \mathrm{Ct}$. Adicionalmente, a expressão de proteínas da via Wnt/ $\beta$-catenina e P53 foi avaliada por imunoistoquímica. Avaliou-se a relação entre possíveis anormalidades moleculares com o fenótipo clínico e o desfecho.

Resultados: A sobrevida geral foi maior em pacientes menores que 5 anos de idade $(\mathrm{p}<0.0001)$ e em pacientes com estágios tumorais menos avançados (p<0.0001). A mutação P53 p.R337H foi encontrada em $87 \%$ dos pacientes e não se associou com características clinicopatológicas ou desfecho. Mutações do gene CTNNB1 foram encontradas em 4/62 (6\%) TAC, todos carreadores da mutação P53 p.R337H. Houve associação entre óbito e presença de mutações do gene CTNNB1 ( $\mathrm{p}=0,02)$. Acúmulo difuso da â-catenina foi observado em $71 \%$ dos TAC, a maioria sem mutações do CTNNB1. Comparados a adrenais normais, os TAC apresentaram aumento da expressão do RNAm de CTNNB1 (p=0.008) e diminuição da expressão de genes inibidores da via Wnt: $D K K 3$ ( $\mathrm{p}<0.0001)$, SFRPl ( $\mathrm{p}=0.05)$ e AXIN1 (p=0.04). Com relação aos genes-alvo da via Wnt/ $\beta$-catenina, TAC apresentaram expressão aumentada de WISP2 e baixa expressão de MYC. Maior sobrevida geral foi associada à expressão baixa de $S F R P 1(\mathrm{p}=0.01), W N T 4(\mathrm{p}=0.004)$ e TCF7 (p<0.01).

Conclusões: Em TAC pediátricos, mutações somáticas ativadoras do gene CTNNB1 são pouco frequentes e parecem estar associadas à maior ocorrência de óbito. Mesmo na ausência de mutações do gene CTNNB1, estes tumores 
apresentaram acúmulo de â-catenina e do gene-alvo WISP2 e expressão reduzida de inibidores da via Wnt (DKK3, SFRP1 e AXIN1). Estes dados demonstram evidências de anormalidades na via Wnt/ $\beta$-catenina em TAC pediátricos, mesmo na ausência de mutações do gene CTNNB1. É provável que outros eventos genéticos afetando a via Wnt//-catenina estejam envolvidos na tumorigênese adrenocortical pediátrica.

\title{
INFECÇÃO PELO VÍRUS DA HEPATITE B: PREVALÊNCIA EM PARTURIENTES ASSISTIDAS EM SERVI- ÇO DE REFERÊNCIA E DETECÇÃO DE PARTÍCULAS VIRAIS E ANTICORPOS NA SECREÇÃO LÁCTEA
}

\author{
Patrícia Ribeiro de Oliveira \\ Orientadora: Profa. Dra. Marisa Márcia Mussi-Pinhata \\ Tese de Doutorado apresentada em 29/09/2011
}

Objetivos: Verificar a soroprevalência de marcadores da infecção pelo vírus da hepatite B (VHB) em parturientes de uma área de baixa endemicidade e avaliar a relação entre a detecção de marcadores virais no sangue e no leite materno, inclusive da quantidade do DNAVHB, em dois grupos de lactantes "AgHBs positivas" e "Anti-HBs positivas".

Métodos: O total de 5844 parturientes do HCFMRP-USP foram triadas para os marcadores AgHBs e anticorpos totais $\mathrm{HBc}$ (anti-HBc) no sangue. Mulheres positivas para o AgHBs eram também testadas para os marcadores AgHBe, Anti-HBe e anticorpos HBc IgM. Mulheres Anti-HBcpositivas/ AgHBs-negativas eram adicionalmente testadas para Anti-HBs. Das mães positivas para o marcador Anti-HBc foram coletadas uma segunda amostra de sangue e uma amostra de leite até 15 dias após o parto. Sangue e leite foram testados por outro ensaio imunoenzimático para confirmação dos marcadores sorológicos e por ensaios de PCR para detecção do DNAVHB.

Resultados: Entre as 5844 mulheres, $211(3,6 \%)$ eram positivas para o marcador anti- HBc. Dessas, 57 [1,0\%; IC95\%: 0,7-1,3] tinham o marcador AgHBs e 128 [2,1\%; IC95\%: 1,8-2,6] o Anti-HBs. As demais 26 [0,5\%; CI95\%:0,3-0,7] mulheres eram somente portadoras do anti-HBc. O marcador AgHBe foi encontrado em 6 (10.7\%) mulheres positivas para AgHBs. Comparação de partículas e anticorpos virais no sangue e leite obtido em torno de 5 dias após o parto foi feita em 55 lactantes (30 AgHBs+ e 25 Anti-HBs+). No grupo de mulheres positivas para anti-HBs somente foram encontrados anticorpos virais, tanto em amostras de sangue quanto de leite, sendo as seguintes as proporções percentuais: Anti-HBs - 100,0/27,3; Anti-HBc - 100,0/13,6; Anti-HBe - 63,6/9,0. A frequência percentual de detecção dos marcadores virais em amostras sanguíneas e lácteas de mulheres AgHBs+ foram, respectivamente, de AgHBs - 100,0/89,0; AgHBe - 11,1/7,4; Anti-HBc total-100,0/74,1; Anti-HBe - 85,2/51,8; Anti-HBs - 0,0/0,0 e DNA-VHB: 63,0/11,1. O DNA-VHB lácteo só foi detectado em mulheres portadoras do AgHBe sanguíneo, que também possuíam os mais altos títulos virais. A carga viral sanguinea variou de zero a 4,7x109 IU/ml e a láctea de zero a 18,2x103 IU/ml.

Conclusões: A proporção de parturientes portadoras de infecção ativa pelo vírus da hepatite B que pode ser potencialmente transmissível para a criança permaneceu estável após uma década nesse grupo populacional. Apesar de termos revelado a presença de $0,5 \%$ de mulheres portadoras de anti-HBc isolado, se essas podem representar risco para transmissão do VHB para os filhos merece estudos adicionais. Quando presentes no sangue, todas as partículas virais e anticorpos do VHB podem ser detectados no leite materno, apesar de que com menor frequência e em menores concentrações do que no sangue materno. Por conterem AgHBs, AgHBe e DNA do VHB, o leite de mulheres portadoras de altas cargas virais sanguíneas deveria ser considerado uma potencial fonte de transmissão viral.

\section{Saúde Mental}

\section{A INFLUÊNCIA DOS PAPÉIS OCUPACIONAIS NA QUALIDADE DE VIDA DE PACIENTES COM ESQUIZOFRENIA}

Tatiane Grigolatto de Paiva Silva

Orientador: Prof. Dr. Jair Licio Ferreira Santos

Dissertação de Mestrado apresentada em 22/07/2011

Introdução: Os transtornos esquizofrênicos comprometem as esferas do funcionamento social, afetivo e produtivo. Em decorrência do período da vida em que se manifesta, pode influenciar diretamente na aquisição dos papéis ocupacio- 
nais e qualidade de vida. Os papéis ocupacionais são funções e práticas que os indivíduos vão adquirindo ao longo da vida, se relacionam com as fases/anseios e sofrem influência do ambiente e das expectativas sociais.

Objetivo: Identificar os papéis ocupacionais e a relação destes com a qualidade de vida em uma amostra de 45 pacientes portadores de esquizofrenia.

Método: Participaram deste estudo 45 pacientes com esquizofrenia de acordo com o critério do DSM-IV, com idade média de 29,4 anos (DP=8,9), sendo 77,8\% do sexo masculino e 45 familiares/responsáveis. Foram utilizados: a) Lista de Identificação de Papéis Ocupacionais, cujo propósito é identificar a percepção do indivíduo em sua participação nos principais papéis ocupacionais ao longo da vida (Parte I), bem como o grau de importância que atribui a cada um destes papéis (Parte II); b) Inventário de Habilidades de Vida Independente (ILSS-BR), utilizado para avaliar o grau de habilidades de pacientes psiquiátricos; c) Escala de Avaliação da Qualidade de Vida de Pacientes com Esquizofrenia (QLS-BR), que acessa informações sobre sintomas e nível geral de funcionamento; d) Escala Calgary de Depressão para Esquizofrenia (ECDE), que quantifica o nível de depressão em esquizofrenia; e) Brief Psychiatric Rating Scale (BPRS), que avalia características clínicas do transtorno. Para análise estatística dos dados, adotou-se como critério valores de $\mathrm{p}<0,05$.

Resultados: Todos os domínios de qualidade de vida (QV), inclusive o global, apresentaram escores compatíveis com QV baixa ou muito baixa. Observou-se correlação positiva entre as escalas ILSS, ECDE, BPRS e os dados sóciodemográficos quanto à ocupação atual e grau de autonomia (Fisher's exact =0,048). Adicionalmente, foi verificada correlação positiva entre papéis ocupacionais e a QV.

Discussão: A Lista de Identificação de Papéis Ocupacionais atendeu aos objetivos deste estudo. Este trabalho poderá propiciar subsídios para futuras intervenções em pacientes com esquizofrenia, além de enfatizar a importância de mais pesquisas sobre instrumentos de Terapia Ocupacional aplicáveis na saúde mental.

\title{
ESTUDO DE VALIDAÇÃO DE INSTRUMENTOS DE RASTREAMENTO PARA TRANSTORNOS DEPRESSIVOS, ABUSO E DEPENDÊNCIA DE ÁLCOOL E TABACO
}

\author{
Carolina de Meneses Gaya \\ Orientador: Prof. Dr. Antonio Waldo Zuardi \\ Tese de Doutorado apresentada em 19/08/2011
}

Os transtornos depressivos, a dependência de tabaco e os transtornos relacionados ao uso de álcool (TRUA) são altamente prevalentes e estão associados a diversas comorbidades. Todavia, permanecem subdiagnosticados e subtratados em diversos contextos de saúde. Dessa forma, o presente estudo teve por objetivos: a) avaliar parâmetros de fidedignidade e validade de instrumentos de rastreamento para transtornos depressivos (Patient Health Questionnaire - two itens [PHQ-2] e Well-Being Index - five itens [WHO-5]), dependência de tabaco (Fagerström Test for Nicotine Dependence [FTND] e Heaviness of Smoking Index [HSI]) e de álcool (Fast Alcohol Screening Test [FAST], CAGE, Alcohol Use Disorders Identification Test [AUDIT] e suas versões breves); b) realizar a análise fatorial do WHO-5, FTND e do AUDIT; c) avaliar a comorbidade entre os transtornos supracitados. Participaram dos estudos da fidedignidade teste-reteste 429 universitários e da fidedignidade interavaliadores 41 pacientes do Centro de Atenção Psicossocial - Álcool e Drogas (CAPS-AD). Os estudos da validade preditiva, consistência interna, comorbidade e análise fatorial utilizaram uma amostra de 530 pacientes do Pronto Socorro e do CAPS-AD. A fidedignidade foi estimada por meio do kappa e do coeficiente de correlação intraclasse (CCI). Nos estudos da validade preditiva, a SCID-CV foi a medida diagnóstica comparativa, sendo calculadas as áreas sob a curva ROC (ASC), sensibilidades, especificidades, acurácias, valores preditivos positivos e negativos dos instrumentos. A validade concorrente foi examinada pelo coeficiente de Spearman. O coeficiente alfa de cronbach foi utilizado para aferir a consistência interna. A análise fatorial exploratória foi realizada segundo os critérios de Kaiser. As comorbidades foram avaliadas por meio da regressão logística - odds ratios brutos e ajustados. O nível de significância foi de p<0,05, com intervalo de confiança de 95\%. O PHQ-2 e do WHO-5 apresentaram altos índices de fidedignidade (>0,98). Exibiram, também, consistências internas elevadas $(0,76$ e 0,78 , respectivamente). O WHO-5 obteve uma ASC de 0,89; sensibilidade de 0,85 e especificidade de 0,81 no ponto de corte nove. O PHQ-2 apresentou uma ASC de 0,86 ; sensibilidade de 0,74 e especificidade de 0,87 no ponto de corte três. O WHO-5 exibiu um único fator que explicou $51 \%$ da variância dos dados. Os estudos da fidedignidade do FTND resultaram em altos CCI (0,92 no teste-reteste e 0,99 no interavaliadores). Na análise fatorial, o FTND exibiu dois fatores. A consistência interna do FTND foi elevada (0,83), já a do HSI esteve abaixo do recomendado (0,56). O FTND e o HSI apresentaram elevados valores de sensibilidade, especi- 
ficidade e acurácia. O AUDIT e suas versões abreviadas apresentaram consistências internas entre 0,83 e 0,94 . No estudo da validade preditiva, esses instrumentos exibiram ASC entre 0,92 a 0,96, com índices de sensibilidade entre 0,84 e 0,93; e de especificidade de 0,83 a 0,94 para rastrear TRUA. A menor versão, o AUDIT-3 obteve excelentes resultados. No estudo da validade concorrente, observaram-se correlações expressivas entre as versões breves e o AUDIT (0,91 - 0,99). Em todas as avaliações o CAGE apresentou valores satisfatórios, porém inferiores aos das versões breves do AUDIT. Os resultados obtidos confirmam a validade e a confiabilidade das versões brasileiras do WHO-5, PHQ-2, FTND e do HSI, assim como, a eficácia de todas as versões breves do AUDIT, demonstrando que suas propriedades psicométricas são tão satisfatórias quanto às do instrumento completo e superiores as do CAGE. Portanto, o emprego desses instrumentos encontra apoio em sua viabilidade e sua validade, incentivando a sua utilização tanto na prática clínica diária como em pesquisas. Observou-se, neste estudo, que o tabagismo e o abuso e dependência do álcool são importantes preditores de transtornos depressivos e que os dependentes de álcool mostraram quatro vezes mais chance de serem tabagistas.

\title{
EVENTOS ESTRESSORES E SUA RELAÇÃO COM MORBIDADE PSIQUIÁTRICA E CONSUMO DE ÁLCOOL E TABACO NA GESTAÇÃO
}

\author{
Larissa Horta Esper \\ Orientador: Prof. Dr. Erikson Felipe Furtado \\ Dissertação de Mestrado apresentada em 29/08/2011
}

Evidências científicas trazem importantes associações entre a vivência de eventos estressores por gestantes e prejuízos a saúde mental materna. Identifica ainda que tal exposição possa estar relacionada ao aumento de consumo de álcool e tabaco por mulheres. Visto os prejuízos para a saúde materna relacionada a esta vivência, este estudo teve por objetivo analisar a relação entre a ocorrência de eventos estressores, morbidade psiquiátrica e consumo de álcool e tabaco em mulheres no terceiro trimestre gestacional. Trata-se de um estudo epidemiológico clínico, observacional, transversal, sobre amostra de 449 gestantes de uma maternidade pública na cidade de Ribeirão Preto-SP. Os instrumentos de coleta foram: um questionário para obtenção de dados sócio-demográficos, relato de uso de tabaco, Questionário de Morbidade Psiquiátrica de Adultos (QMPA) e entrevista para eventos recentes de vida (IRLE). Para avaliação do consumo de álcool foi utilizado o instrumento T-ACE (Tolerance, Annoyed, Cut-down, Eye-Opener) e um questionário para avaliação segundo critérios de pesquisa da CID-10 para uso nocivo ou síndrome de dependência. Os eventos estressores receberam três tipos de análises: isolados, agrupados em categorias e através da somatória total. Os resultados demonstraram que todas as participantes reportaram ter vivenciado algum evento estressor durante o período avaliado $(\mu=5 ; \mathrm{dp}=2,2 ; \min =1$, máx = 14) com destaque para a categoria "saúde" $(99,1 \%)$. Quanto aos eventos estressores específicos, a "gravidez indesejada" $(60,5 \% ; \mathrm{n}=272)$ e "dificuldade financeira média" $(31,8 \% ; \mathrm{n}=143)$ foram os mais frequentes. O primeiro evento estressor recebeu elevado impacto de estresse, 97 gestantes referiram estresse alto ou acentuado, 128 estresse baixo ou moderado e apenas 47 nenhum estresse. A somatória total de eventos estressores ( $p<0,001)$ e as categorias "Educação", "Finanças", "Aspectos legais", "Migração" e "Trabalho" apresentaram correlação estatística significante em relação à morbidade psiquiátrica $(\mathrm{p}<0,001)$. Os eventos "dificuldade financeira média ou grande" e "brigas com familiares" foram cerca de 3,5 vezes maior em gestantes com suspeição de transtorno psiquiátrico ( $\mathrm{p}<0,001$; 95\% IC:2,16-3,84). Em relação ao consumo de álcool, o número total de eventos e a categoria "Finanças" apresentaram correlação estatística significante com o consumo de risco e uso nocivo ou dependência. $\mathrm{O}$ uso de tabaco foi associado à categoria "finanças" $(\mathrm{p}<0,05)$ e aos eventos "gravidez indesejada" ( $\mathrm{p}<0,001 ; 95 \% \mathrm{IC}: 1,4-4,9)$ e "brigas com o marido" ( $\mathrm{p}<0,05 ; 95 \% \mathrm{IC}: 0,8-3,1)$. Os dados apontam alta vivência materna de eventos estressores durante o período gestacional e associação entre eventos estressores (isolados ou em categorias), sintomas psiquiátricos, consumo de álcool e tabaco. A avaliação dos eventos estressores por profissionais de saúde torna-se, portanto útil para o tratamento, educação e promoção da saúde pública visto que pode ajudar as mulheres a reforçar os seus estilos de enfrentamento ao estresse e prevenir o consumo de substâncias lícitas e danos à saúde mental materna. 


\title{
Saúde na Comunidade
}

\section{RECURSOS E NECESSIDADES DE PROFISSIONAIS DA ESTRATÉGIA SAÚDE DA FAMÍLIA PARA LIDAR COM QUESTÕES RELACIONADAS À SAÚDE MENTAL}

\author{
Mariana de Oliveira Pasqualin Ribeiro \\ Orientadora: Profa. Dra. Maria do Carmo Gullaci Guimarães Caccia Bava \\ Dissertação de Mestrado apresentada em 12/08/2011
}

Um dos pilares da política de Atenção Básica do Sistema Único de Saúde (SUS), a Estratégia Saúde da Família (ESF), realiza em equipe, assistência descentralizada nos territórios adscritos e deve conseguir resolver a maioria das demandas em saúde, parte delas advinda da saúde mental. Nesta estratégia, a formação de vínculos positivos e o lidar com o sofrimento humano de forma sistemática representam grandes desafios, que podem ser exacerbados em se tratando de pessoas em sofrimento mental. Foi a partir deste contexto que este trabalho definiu como objetivo produzir sentidos sobre os recursos e necessidades para lidar com questões relacionadas à Saúde Mental com trabalhadores da ESF, do Município de Serra Azul, Estado de São Paulo. O referencial metodológico qualitativo foi utilizado para a análise dos dados a partir do construcionismo social e como instrumento de coleta foi utilizado o recurso do Grupo Focal. Participaram deste estudo os profissionais das duas unidades de saúde da família do Município de Serra Azul. A análise das entrevistas teve início com a transcrição e edição do material gravado. Posteriormente, a pesquisadora realizou uma pré-análise, que consistiu na leitura exaustiva das entrevistas e a imersão em seus conteúdos. Nesta fase, optou-se pela análise de apenas uma das entrevistas realizadas, a que pareceu a mais rica e fértil para os objetivos do presente estudo. A análise (composta pela apresentação dos resultados e da discussão) apontou a construção de sentidos pela equipe de necessidades e recursos existentes no cuidado aos pacientes com problemas de saúde mental. As necessidades descritas foram divididas em três subtemas, que são a falta de estruturas no Município para acolher estes pacientes fora das unidades de saúde, a falta de recursos dos pacientes atendidos e a falta de capacitação e preparo da equipe para este tipo de cuidado. Outro tema apresentado como resultado da análise foi os recursos existentes e não reconhecidos pela equipe para o cuidado a esses pacientes. Foi possível perceber que a criação de espaços de conversa onde estas equipes possam reconhecer seus recursos, trabalhar suas ansiedades e dar novas descrições para suas ações podem contribuir para melhorar o atendimento em saúde mental na Atenção Básica.

\section{PADRÕES ESPAÇO-TEMPORAIS DA INCIDÊNCIA DA TUBERCULOSE EM RIBEIRÃO PRETO: USO DE UM MODELO AUTO-REGRESSIVO CONDICIONAL}

\author{
Daiane Leite da Roza \\ Orientador: Prof. Dr. Edson Zangiacomi Martiez \\ Dissertação de Mestrado apresentada em 24/08/2011
}

Neste trabalho foram utilizados modelos de regressão espaço-temporais bayesianos para estimar a incidência de TB em Ribeirão Preto (anos de 2006 a 2009) por área de abrangência de unidades de saúde, associando-a a covariáveis de interesse (IPVS, Renda e Educação predominantes naquelas áreas). O método baseia-se em simulações MCMC para estimar as distribuições a posteriori das incidências de TB em Ribeirão Preto. Como resultado, temos mapas que mostram mais claramente um padrão espacial, com estimativas mais suavizadas e com menos flutuações aleatórias. Observamos que as áreas com as mais altas taxas de incidência também possuem índice de vulnerabilidade social médio e alto. Em relação à renda, a faixa salarial predominante dos responsáveis pelo domicílio nestas regiões é entre 0 e 3 salários mínimos e o nível de escolaridade predominante dos chefes do domicílio nestas regiões é o ensino fundamental. Os resultados dos modelos bayesianos analisados nos evidenciam que com o aumento da vulnerabilidade social aumentamos significativamente a incidência de TB em Ribeirão Preto. Nas áreas onde a vulnerabilidade é alta a incidência de TB chega a quase 15 vezes a incidência das áreas sem vulnerabilidade. Houve um aumento significativo em relação à incidência de tuberculose em Ribeirão Preto durante os anos estudados, sendo as maiores incidências registradas no ano de 2009. O uso de mapas facilitou a visualização de áreas que merecem uma atenção especial no controle da TB, além disso, a associação da doença 
com renda, escolaridade e vulnerabilidade social trazem subsídios para que os gestores responsáveis pelo planejamento do município planejem intervenções com uma atenção especial a estas áreas, reunindo esforços para a redução da pobreza e da desigualdade social, alternativas para uma melhor distribuição de renda e melhorar o acesso ao saneamento básico dentre outras prioridades.

\title{
PERCEPÇÕES DE MÉDICOS E ENFERMEIROS ACERCA DA VIOLÊNCIA CONTRA A MULHER: UMA ANÁLISE COMPARATIVA
}

\author{
Mariana Hasse \\ Orientadora: Profa. Dra. Elisabeth Meloni Vieira \\ Dissertação de Mestrado apresentada em 30/08/2011
}

Este trabalho foi desenvolvido como subprojeto integrante da pesquisa "A Interface Entre a Ocorrência e o Atendimento de Violência de Gênero Entre Mulheres Usuárias dos Serviços de Saúde da Rede Pública de Ribeirão Preto”. A violência contra a mulher é uma das expressões mais perversas da subordinação feminina e gera graves consequências para as pessoas que vivenciam o seu ciclo. Mulheres nessa situação buscam frequentemente os serviços de saúde, que possuem um alto poder de deteç̧ão da violência. Porém, há uma série de dificuldades por parte dos profissionais, médicos e enfermeiros, em identificar e prestar assistência adequada a essas mulheres. O objetivo deste estudo foi analisar comparativamente as percepções de médicos e enfermeiros que atuam na rede de saúde de Ribeirão Preto acerca da violência contra a mulher buscando formas de aprimorar a assistência prestada. Para isso, realizamos uma pesquisa qualitativa, utilizando um banco de dados de 14 entrevistas com médicos e 10 com enfermeiros, realizadas por meio de um roteiro semiestruturado. Por meio de análise de conteúdo temático foram identificadas as seguintes categorias: 1) Percepções sobre gênero; 2) Percepções sobre a violência contra a mulher; 3) Sobre atuação profissional; e 4) Sobre a rede de proteção. Tais categorias foram divididas em diversas subcategorias que foram analisadas a partir do referencial de gênero. Os resultados mostraram que há muitas semelhanças nas percepções relativas às questões de gênero, que são ainda bastante tradicionais. Os profissionais entendem que a violência contra a mulher ocorre devido às desigualdades perpetuadas pelo sistema social e que acabam por justificar a violência. Eles reconhecem os tipos de violência existentes e estão aptos a identificar e acolher as mulheres nos serviços de saúde, reconhecendo tais ações como suas responsabilidades. Porém, muitas vezes não o fazem por barreiras como a própria estrutura dos serviços, a falta de capacitação e aspectos emocionais, que dificultam o acolhimento e a orientação adequados. Também identificamos que a rede de apoio existente ainda é desconhecida por muitos dos profissionais e, diversas vezes, está estruturada de forma inadequada para atender às demandas existentes. Assim, é fundamental o desenvolvimento de capacitações para os profissionais da área de saúde com o objetivo de prepará-los para uma melhor assistência às mulheres em situação de violência e para o conhecimento da rede de proteção existente. Além disso, é urgente que a estrutura dos serviços seja repensada em diversos aspectos para que os princípios do SUS e as ações de humanização possam, de fato, ser colocadas em prática.

\section{ACIDENTES E DOENÇAS RELACIONADAS AO TRABALHO NA INDÚSTRIA DE CALÇADOS DE FRANCA-SP}

\author{
Dathiê de Mello Franco-Benatti \\ Orientadora: Profa. Dra. Vera Lucia Navarro \\ Dissertação de Mestrado apresentada em 02/09/2011
}

O mundo do trabalho vive um extraordinário avanço tecnológico caracterizado pela introdução de modernas tecnologias, automação acelerada, que resultam em novas formas de racionalização e organização do trabalho e no aumento da exploração intensiva da força de trabalho. Esse processo foi marcado pela reestruturação produtiva, que resultou em maior intensificação e precarização do trabalho, fatos que refletiram nas relações e nas condições laborais. $\mathrm{O}$ setor calçadista, conhecido pela grande capacidade de geração de empregos, também foi atingido por essas mudanças, com consequentes agravos à saúde de seus trabalhadores. Tendo como pano de fundo este quadro de transformações, foi objetivo da pesquisa investigar como se acidentam e adoecem no trabalho os trabalhadores envolvidos na produção de 
calçados em Franca (SP) e como isto repercute em suas vidas, dentro e fora do espaço produtivo. A pesquisa, de cunho qualitativo, teve como principal técnica de coleta de dados a entrevista. Foram entrevistados 20 trabalhadores, 15 mulheres e cinco homens; um profissional da área da saúde e dois representantes do Sindicato dos Trabalhadores nas Indústrias de Calçados de Franca. Os trabalhadores entrevistados foram contatados através do sindicato da categoria, que também forneceu as Comunicações de Acidentes de Trabalho (CATs) utilizadas como fonte de informações. Os resultados demonstraram que o trabalho na produção de calçados tem sido fonte de agravos à saúde dos trabalhadores. Os dados obtidos pela pesquisa permitiram relacionar os acidentes e doenças apresentados pelos trabalhadores à organização e às condições do trabalho às quais estão submetidos. As principais queixas foram: LER - lesões por esforços repetitivos, ferimentos corto-contusos, amputações de membros superiores (mãos, dedos, antebraços e braços), dores lombares, estresse, depressão, ansiedade, tristeza, angústia, além de terem se referido a sentimentos de insatisfação e desvalorização no trabalho. Os dados revelaram também como os episódios de acidentes e doenças ocupacionais repercutiram na vida dos trabalhadores. A violência sofrida pelos trabalhadores não se resumiu apenas ao acidente em si e às circunstâncias em que ocorreu, mas se estendeu pelo longo processo de tratamento e pela trajetória institucional percorrida para estabelecer o nexo entre o acidente e/ou doença e o seu trabalho. 